University of Louisville

ThinkIR: The University of Louisville's Institutional Repository

Electronic Theses and Dissertations

1932

\title{
The effect of hydrogen ion concentration on the color of metallic chromates.
}

John E. Morris

University of Louisville

Follow this and additional works at: https://ir.library.louisville.edu/etd

Part of the Inorganic Chemistry Commons

\section{Recommended Citation}

Morris, John E., "The effect of hydrogen ion concentration on the color of metallic chromates." (1932). Electronic Theses and Dissertations. Paper 1841.

https://doi.org/10.18297/etd/1841

This Master's Thesis is brought to you for free and open access by ThinkIR: The University of Louisville's Institutional Repository. It has been accepted for inclusion in Electronic Theses and Dissertations by an authorized administrator of ThinkIR: The University of Louisville's Institutional Repository. This title appears here courtesy of the author, who has retained all other copyrights. For more information, please contact thinkir@louisville.edu. 


\title{
MIVBRBIX of LOUTBVITK
}

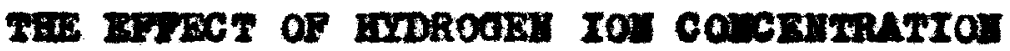
o8 mis conon of ushature choums.

\author{
A Diseortation \\ Subaltted to the pooulty \\ of the Oraduate sohool \\ In Fartial Fulfilinent of the \\ Begal rewont: for the Dogree of \\ Mater of solenes
}

Dopartanent of Choileter

\author{
By \\ Jole E.Haris \\ 108
}


Tuble of Contrate.

moratures 2

Boportmontal

Apparatue 9

Interiels 29

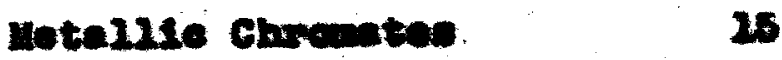

Gepper Guremen. : 19

stares ghromito. 5

Uagoelum chronto $\quad 45$

Calelom Ghromate 48

Strontim Gumato 62

Bantum Ginounte as

2ino Ghromat . 6

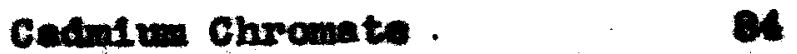

Earourde chromed. os

Almotnu Chronte . 205

Ttentem chmanto $10 \%$

Stannan Chwante. $\quad 169$

Aronio Ghronate. 119

Antinow chromto $\quad 126$

Bloment chromete . $\quad 215$

29135 
Iron Chrouste.

Cobalt Chrowate.

ILoke2 Chromate.

sumas

BLbllogrephy
204

207

23

20

149 
Molnom leagement.

The enthes olves to exprese hit

approdiation to the

021. Paint and Vamioh clvb

of Lousaville

whowe sholerehtp made poestble

this seceazoh

and to

De. Robort Craig bunet

for direatine

this researeh. 
1

2

IIIRODUCrTON 
Intrealustion.

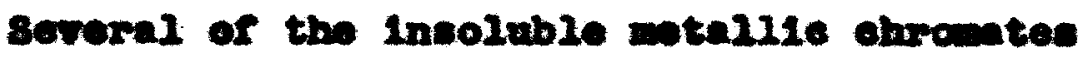
are uned axtensively as coloxed pitmente in the paint Incuetry. 2he wost importent of those is $20 a d$ although others, as cadut un and barium, form insoluble or elightif coluble ohromates which are aleo onitable for uee an pigmente."

The load ealte have beon investigeted by verion exporimonters wo have atudied the rolation of the color of those chromates to suoh faeters as bydrogen ion concentration, dispernion, parilole sise, abemical conetitutica, ote.

The ineoluble ohromates axe preelpitated fron a diute solution of the metali1e selt alther with soalvin or poteselum abromates or diohromates. Brat (1) and others found that the variation of the modrogen Ion ooneentration of the colutione does affect the rooulting oolor of lead chrowate plgmonte but the acte or base used to affect the ohange of pill does not ohange tho ooler. Hel ther does the we of the different alkall chrenates of adium or potasIn nor the áchroustes of these metale have eny anibed effedt on the color. The tim of striking 
and the temperature of the solution e had no effect. more fore it is believed the hydrogen $10 n$ coneentixiion of the solutions is a determining factor in controlling the color of the chromate pigment.

It is the purpose of this investigation to prepare other metallic chromates and study the effect the hydrogen ion ocmeontration of the volutions bee on the resulting color. 
$-$

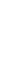

-
-

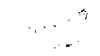

-

EXPERTIMUTAL

- 


\section{Experimental.}

The purpose of this investigation was the proparation of different metolile ohroantes by proe1pltation from solutions having different hydrogen 10 ocncontrations and the study of the coler of the resulting ohrometes.

The brirogen 100 consentretion of the solution was determined by the potentionetrie wethed of Emat, Pragorf, and Iftkonhous, (1). In this wothel the electrowotive foree of cell consisting of the solution with the caturated oelomel electrole as inelf-eell and the quinhrdrone eleotrode or Belmann (34) as the Indicator eleotrode. Is moanred. The relatica between the measured electromotive force and the pH (acoording to Stronsen) (35) is

$\mathrm{E}=0.4526-0.0591208 \mathrm{pH}$ at $25^{\circ} \mathrm{c}$.

The eleetremotive foree was determined by the we of the potenticaster uning the ofreult shom In Mgare 1. The guinhydrone olootrod uned alpped direotiy into the solution during the titration. The celomel eleotrode wes conneeted to the solution by mans of the selt bridge (potansium obloride and -garmagar). 
The brarogen Ion conoentration was varied by the acld having the comon ion of the wotallie salt, that is all solutions made rrom the watalise ohloride wore ramed with hydroohlomio aeld and those from motellio nitrates were raried with nitrie eold. since only sodive dichromate we ueed in this investigation sodim hydroxide was the only base used. tho eold: and base uned were approximately 5 normal. The pH of the solutions wore verled from

1 to 11. AlI pH above ore doubtrul (37). Tho pH of the diohromete solutions comresponding to the

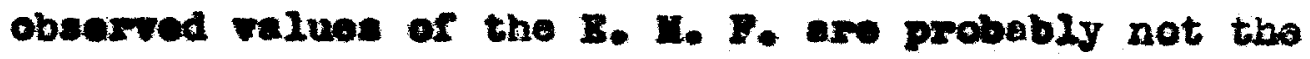
true pH valuos.

It was attempted to prepare the colors under three different oonditions in order to see if the mothod of proolpitating had eny marked effoet on the rooulting oolor.

1. The diehromate solution was $\operatorname{sen}$ into the motel110 icn solution, the hydrogen lon conoentration of the motelile lon solution veried, while that of the dichromote solution wes holl econstant. 2. Tho diehramato volution was ron into the motellic ion solution, the hydrogen 100 concentration of the dichromate solution varied, while that of the metellic lon was held constant. 
3. Tho motelile 100 solution was run inte the Alehromete solution, the hrdrogen lon concentratien of the wallie Ion olution wes varled whlle that of the dichress to was hold econotant.

411 solutlons uned wore .5 normal whon etruok. The eolutione rore made up so that aftar tho addition of the cold or bace the volume covld be wade up so the coneentretion of the dealmed 100 would be 5 normal. A quantity of motal110 son volution was taken that would give eppracimately 15 grape of dried plgment, and wes proolpitated with a volwe of diehrom

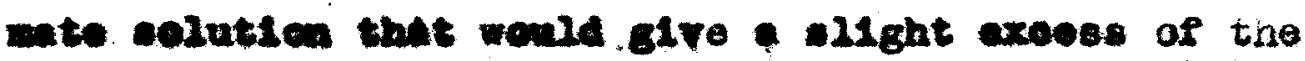
ehremte 1en. This Insured a nore ecuplete proelpitation of the motali1e chromate. The eclutio wae agiteted during and approuinately ton minutes ofter the mixing. After this period of agitotion the final pH or the solution wes secorded and a eample of the pulp color wes removed and placed in a stoppered tost tube, the remalnder of the color was wahed five times by decanteticn, with approximately a 11 tor of weter oceh waching. The color was then flitered a d pleod in an oven, at a terperaturo of 75 - 80 degrees Centegrade for 24 hours. or unt1l dry. 
The pulp colore, after having been pleoed In atoppered toet tubes wero ocmpared with tho oolor plates in userve and Paw pletionary of color (38). All zeremoees to this dieblonery aro given in the form 78 -10L, whleh woans that the eolor is on color plete number 8 and in the expe corropponding to $10 \mathrm{r}$ on the obart.

The mase tones vere rubbed in bleached IInseed ofl to a paste, and thon placed on glese slides and ecmpared with the Dietlonary of Color. The colors chem herefn pere prepared the sam way and pleced on carboard.

The $\mathrm{p} B$ ralues for the colutions whe -truel corresponded to the following R.X.F. Ilsted in rolts.

$\begin{array}{rrrr}1 & -.3045 & 7 & -.0506 \\ 2 & -.3568 & 8 & +.0206 \\ 3 & -.2726 & 9 & +.0707 \\ 4 & -.2100 & 10 & \$ .1400 \\ 6 & -. .1676 & 11 & +.2000 \\ 6 & -.0007 & & \end{array}$

ALI values were taken from a Loede-Morthup Converaton rable. 
APRARATUS 
Apparatio.

Tho apporatus wed in this invostigetion

for woseving the rodrogen 1 on concentration sonoleted or a Ioeds and Marthrup Studont Potentionster clroult.

Figne I.

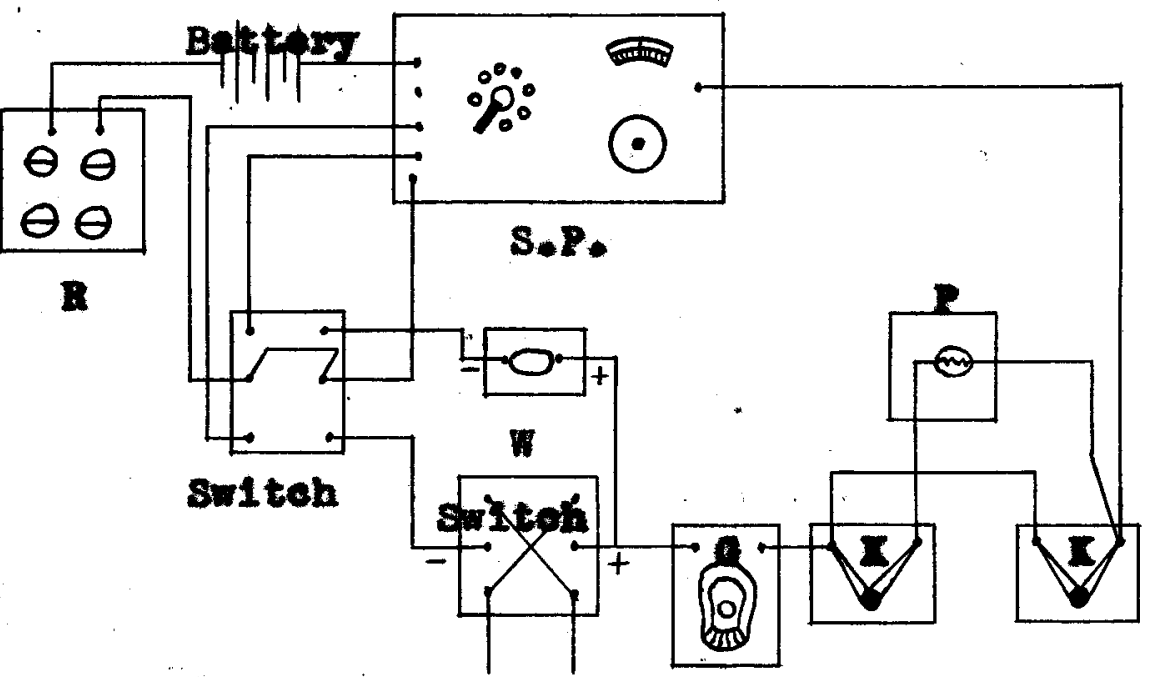

To Bleetrode.

8.P. Is a student potenticueter (range 0 to 1.6 volte. 800 divielon meeles, 0.5 millvoit acenragy.

Batery is a dry cell bettory of 2.5 velte.

R. Is a realetanoe bex ( 1 to 1000 obes).

switohes are D.P.D.T. sutebos.

P. 1s a protective resintance of 10,000 obme 
6. Is a D'Araenval Galvancmetor 10.5 milexemparese

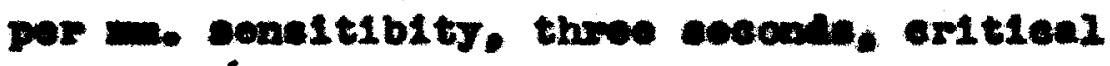
Anding sealatanes 2400 obne.

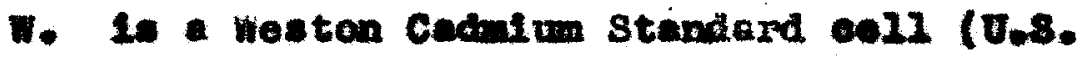
Buroun of Stnudard callbrat10r 1.020es Interm national Volte at $22^{\circ}$ contograde.

I. I are tap Kaye. 
$\therefore$

merarars

o 
watoriele.

The materials weed in this investigetion were elther C.P. selts or were neoryatelised. The codium dichromete wa recryatalilsed from a distilled water elution heving a bolling polnt 210 - 195 degrees Centegrede. It wat found that belon 280 degreos no ergetelis would form and beve 125 degrees the solution would solidify. Small eryotale were obteined by rapld cooling and constant stireing tho salution.

The following wetallio salts were used in the preparetion of the ohromates.

1. Coppor nitrate

2. SLlver nitrate

3. Lagnasium nitrate

4. Calelen nitrato

5. Stroative ohloride

6. Barium ahzoride

7. Zine aitrete

8. Cedaiun nitrate

- Merourio nitrato

10. Aluminum nitrate

12. Mtaniun trioblorida

28. Stannoue chloride 
23. Areonic axide

24. Antimony triohloride

15. B1emath nitrate

16. Menganese ohloride

17. Fexrous obloride

18. Ferrie ohlomide

19. Cobaltous ohloride

20. Niokelous aitrete.

The acide and base uned wore of the highest purity. 



\section{Uotel21e Chromatoe.}

The motallie chromates an ente of onroule ecid, and are analagous to sulphates in mong reopects, onpoelaliy colubility. Thus, the alkell chromates and those of magnesiva and eelalvm are solubls while lacd and barlum are practleally" insoluble. The metallie diehromates are salta of aichromis ac1d. In a solution of an ellenli diohrote both the obromate and the dichramte 100 are preaent. Therefore when metelific selt is added to - diohromate solution tho ohromate or dichromate ray prosipitate, doponding on wioh is the 2east caluble. This ecoounte for the fect that load ehromate, and other motalilo ohromates, are predpitated rrom dichromet solutions.

rost incolnbie motalife chrowetes are of some shede of yellow. ( ). The lead ard berlum probably belng the most secmon, are both jellem the bariun chroute belng a IIghter shede. Wotallis

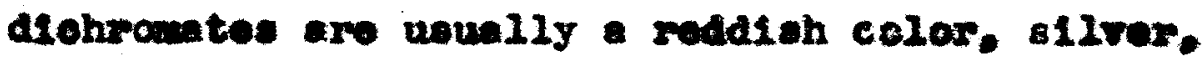
beling a good axcaple is a zeddieh brom. Notall10 ohromates do not form seld salte as do the sulphates but they do form besie salts. 


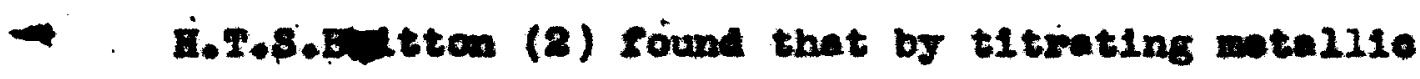
salts with potanelum chromate a basic salt would farm at the eame $\mathrm{pH}$ as the hydrexide of the motel. Ho Inveatigated several motallie ealti (HI, Co, M, Zn, Th, and other rare elomente) and found this to bo a general fact. 


\section{CORPER GRROMATE}




\section{Coppor chromato.}

- The norwel eopper ohromate ves propared by J. Sohvise (8) by heating ooppor hidroxide and potanelum dichremete in a seeled tube at 280 degreos. He desertbed the produet as bolng tron-black or redaloh brown with the appoaranes of boamatite. Tho normel selt was innoluble in watex, but hydrolysed In hot wator to a bele salt. Dnder ordinary conditlons sohulse and othore found a bale ealt was formed from bolling selution of coppor hydroxide and a dohramate.

I. H. Vaugueiln (O) found thet a obeotnut brown precipitate formed when neutral salt of copper was trested with potesalum chromete. This ealt upon anazyele conelated of $\mathrm{K}_{2} 0 \cdot 36 \mathrm{rO}_{5} \cdot 8 \mathrm{H}_{2} \mathrm{O}$. 4. aroger (33) obtalned a greenlsb-yellem prealp1tete from copper ohleride and sodium ahromate, whioh abanged to a maty brom when loft in contact with the mother 11quor. The compoultion of the greonich-

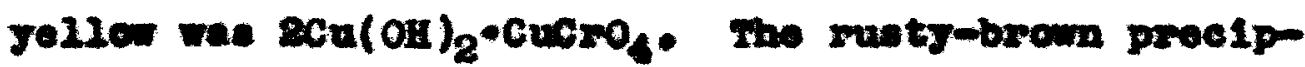
1tate roverted to the greoniab-joliem noen wabing. 
Tabie I.

Bffoet of Vaplation of Hyarogen Ion Ceavontratien of Coppor Hitrate selutione with Itria

cold and sedim byirmide.

(Sodive dichromato" added to oeppor nitrato.)

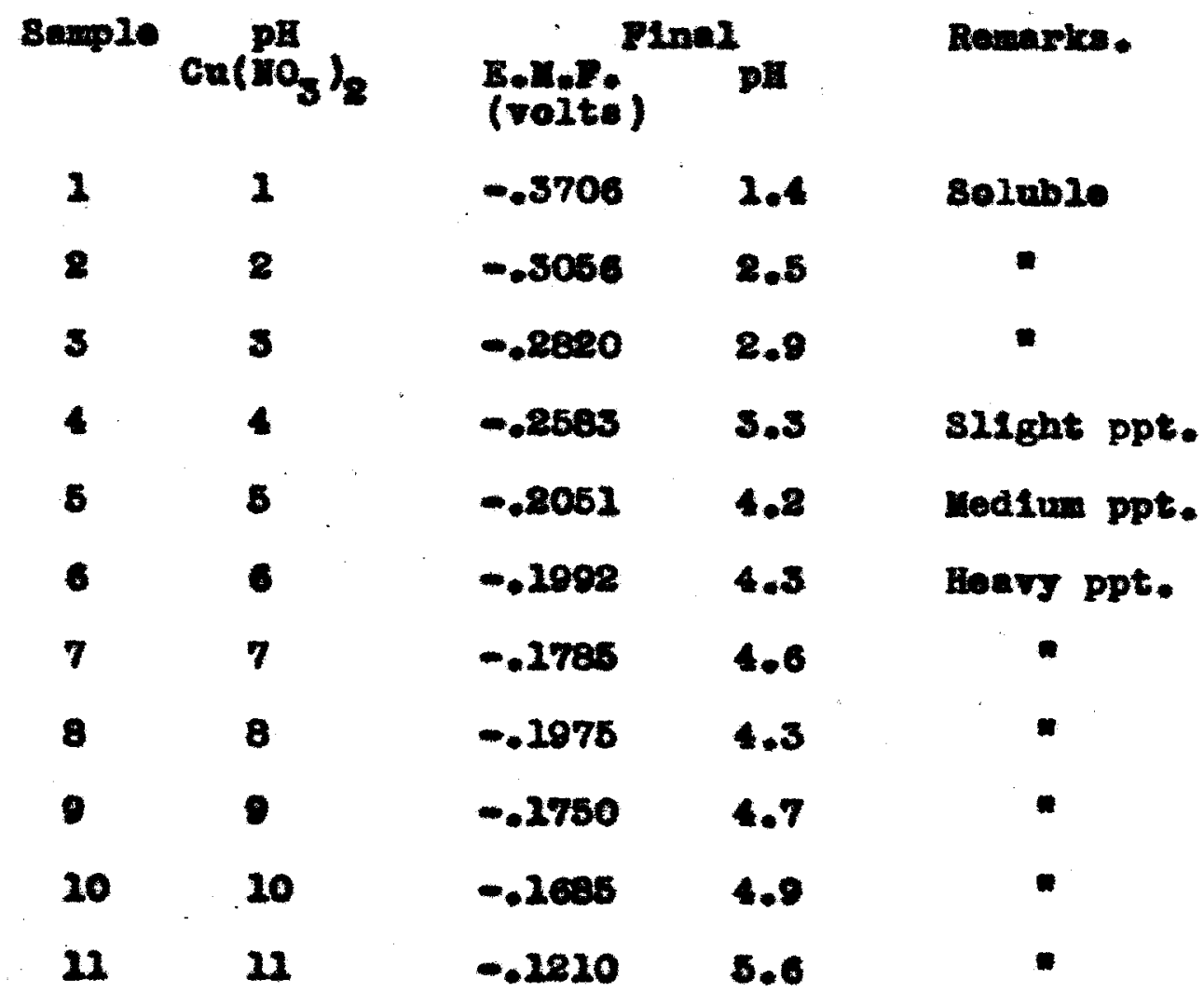

- The pH of the sodium dichromete 2.5. Timo of strilang was 81 soconde. On washing the procipltate the resulting colutione were colored due to the ellght solubility of the plgoent or to hydrolyeie. 


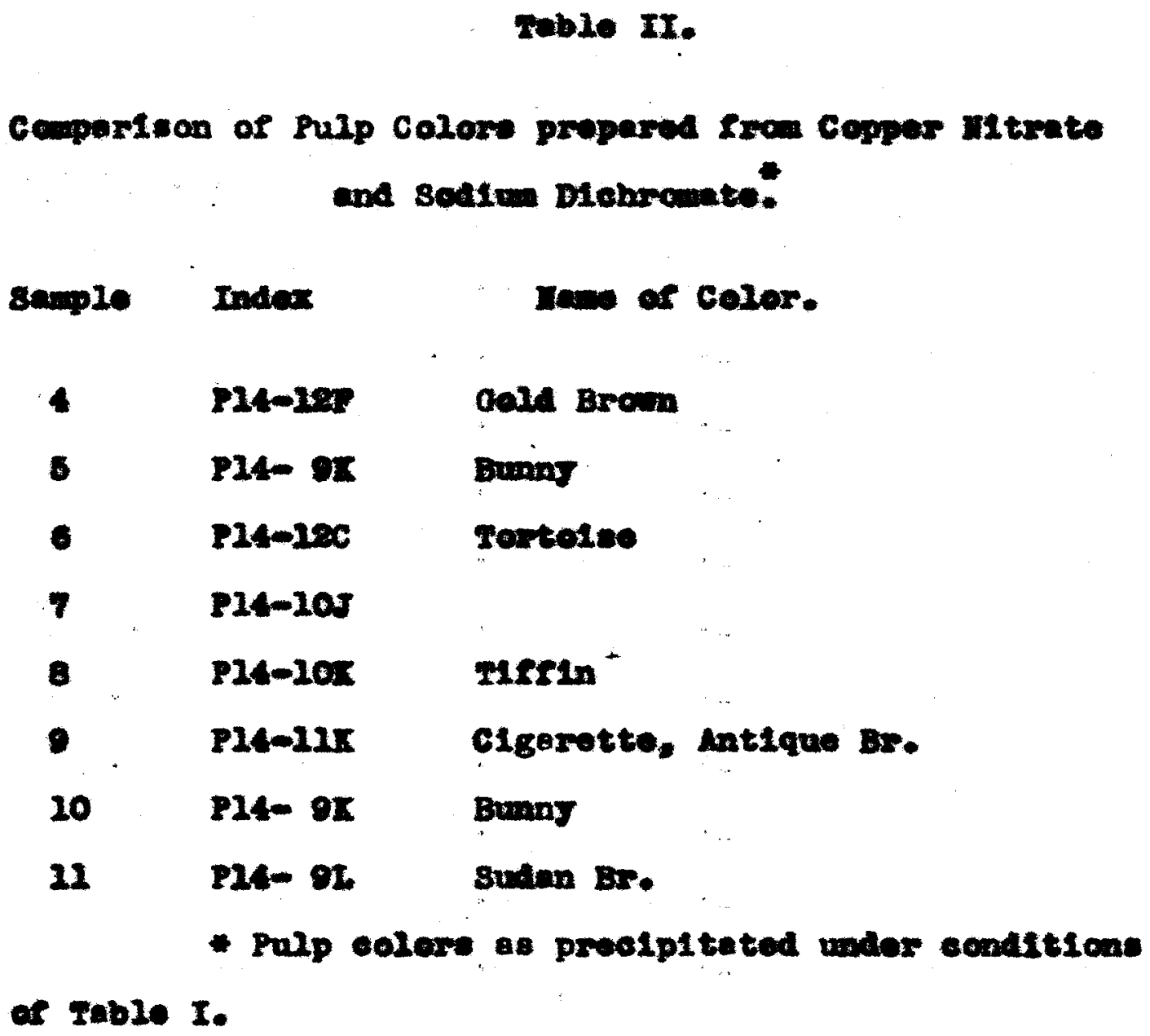

Iubers $2,2,3$ were almost complotely soluble

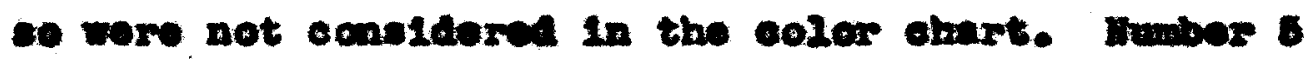
was on offohode, no apparant reason. Thowe was a ellght break at pH of $10(110,10)$ Irom a red-brom to - gropombrom. Humber 5, 8, 10, 11 ehowed allght Change in color whore the plgment was in conteot with the exporsatent 11quid, which contalned ohromate and gutilutarene. The others shomed 11 ttle or no change. 
41 the ohanges wore to a darker brem, The sames axcopt for arfohades varied from a mah-brom to a creonobrom.

\section{Iable III.}

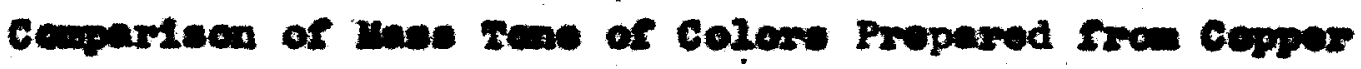
Bltzate and sedivin Dlohromete".

8ample Index Iane of color.

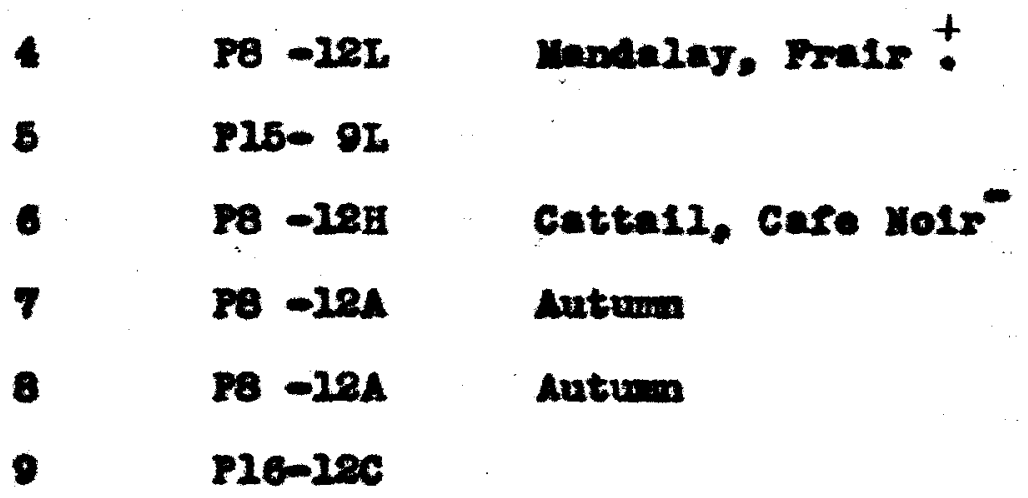

$10 \quad 78-121$ Antum

$21 \quad$ P13- 21

- Color propared under conditione of Tablo I.

The sorion verios from a brom (He. 4)

through a groadioh brown (Nos. 5 - 10) thon to a Iight groam-jelion (Ho. 21). Humbers 5 and 0 are ofrahados belng mare green than brown. All the colore are brighter thes the Auplieate in color chart. 41 the greenbrome are a disty color. 
colos chart 1.

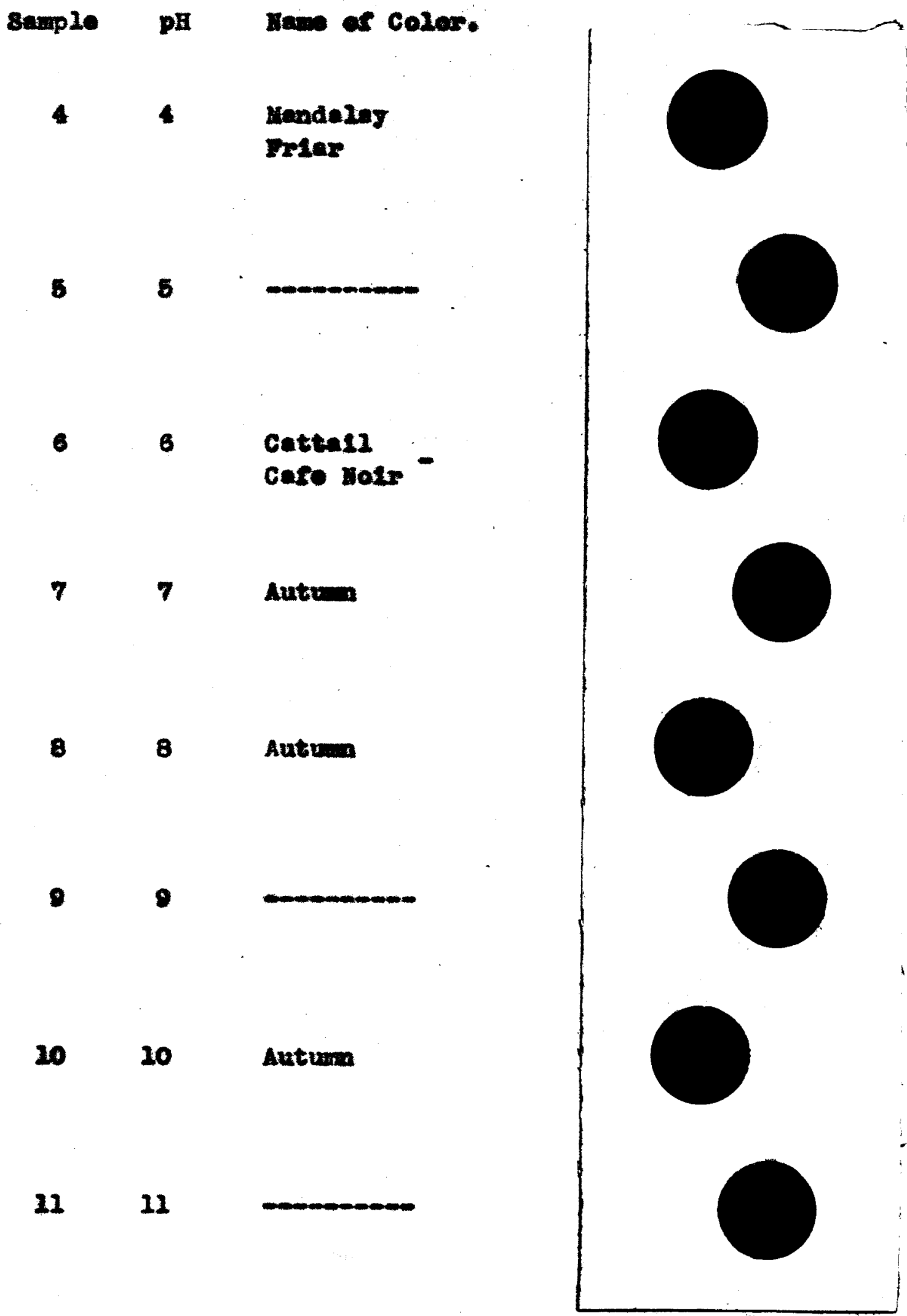


2ab2e $\mathrm{I}$.

Brfeat of Variation of Hydrogen Ien Ceneentration of sodive Diobrowote colutions with Iitrie sold and Sodium Hyaromide. (Sodive diohromate added to oopper intrato".)

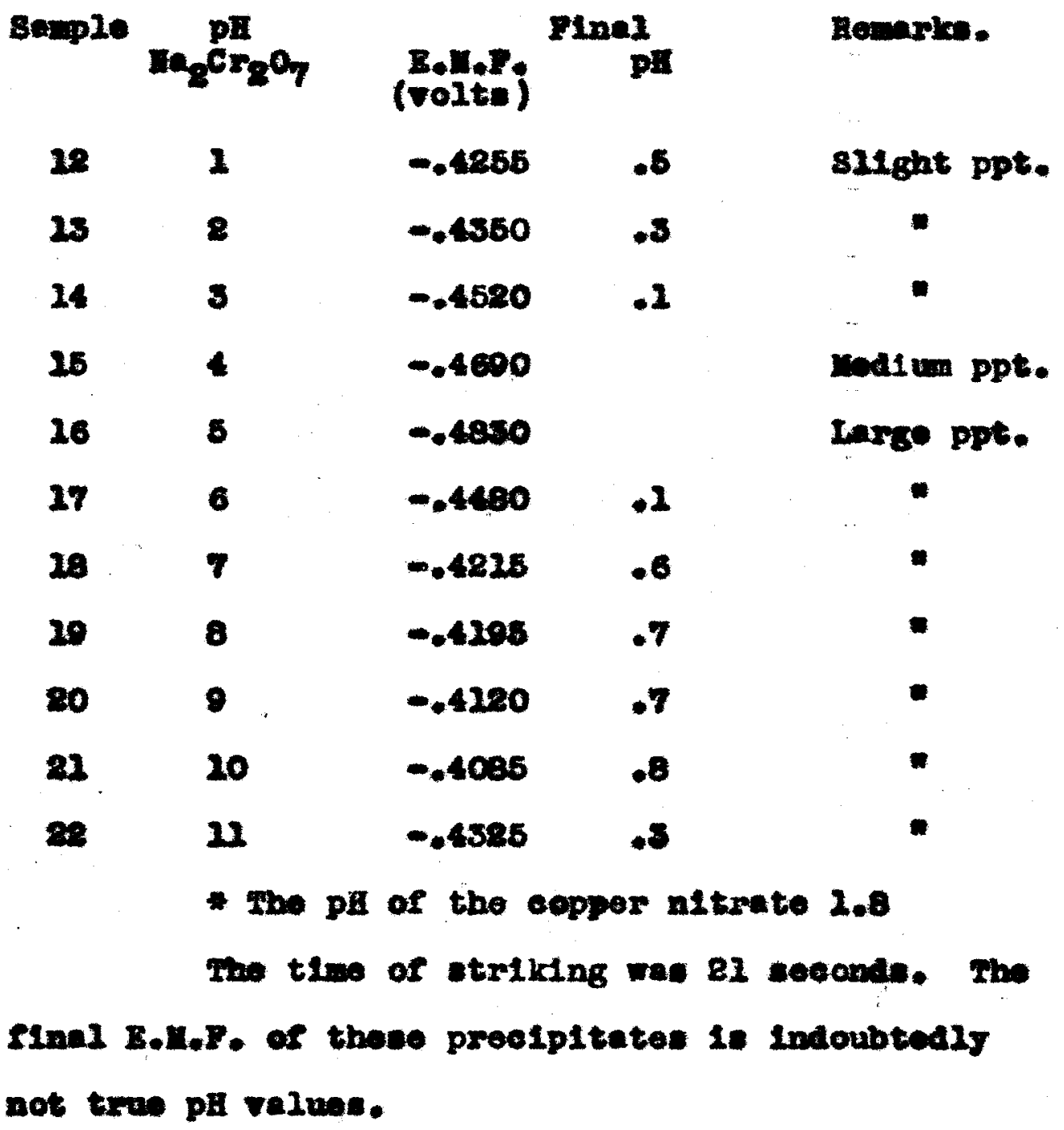


Tobie 7.

Cemparieon of Pulp Colore propared from Copper ultrate and sollu Diehremete.

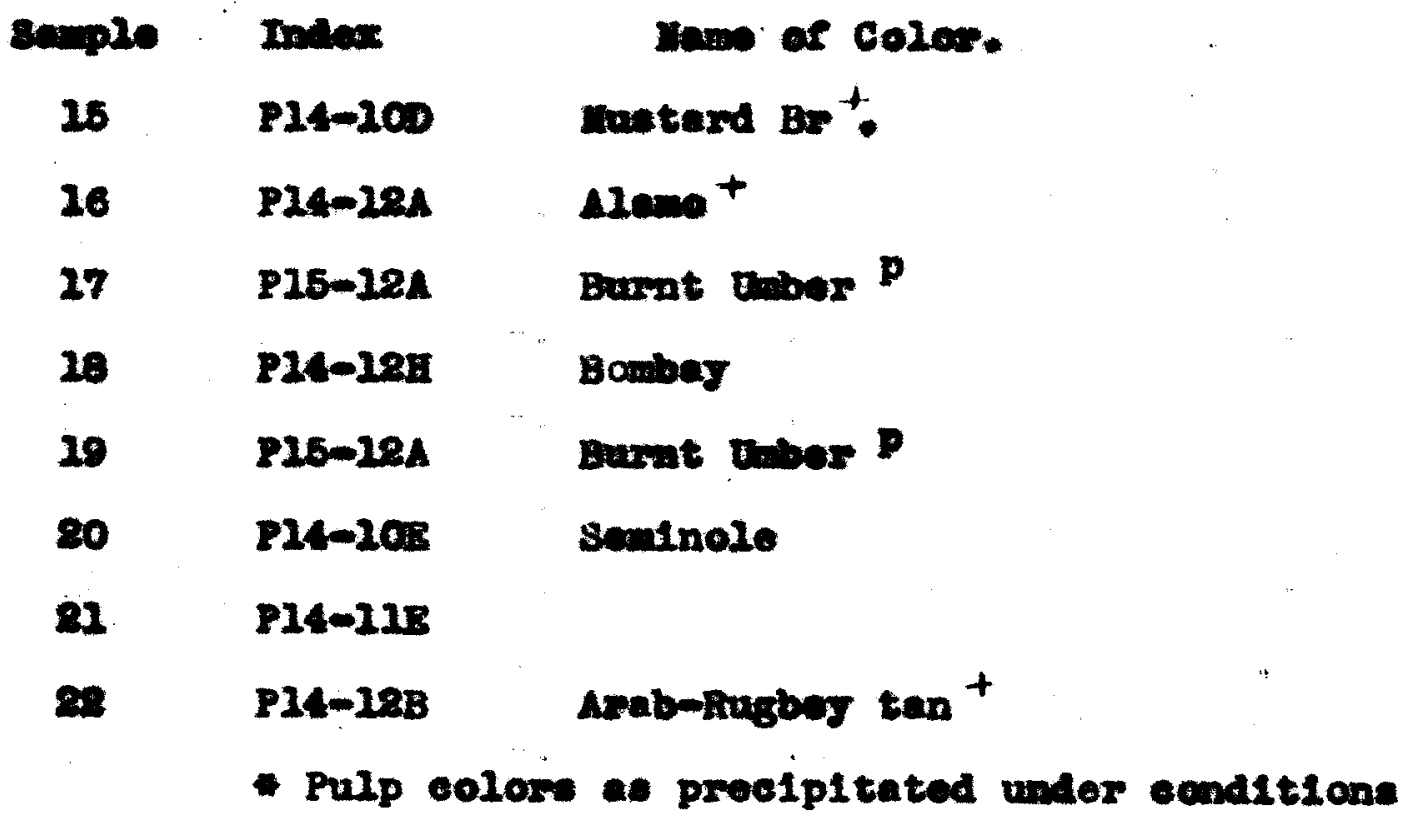

af rable IV.

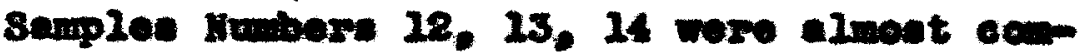
plotely weluble so wore not considernd in the colar ahart. Iumbers 18 and 20 wem arrahades. 141 the oclere excopt number 20 showed change of ooler whore In ecatest with tho supornatent ilquor continding

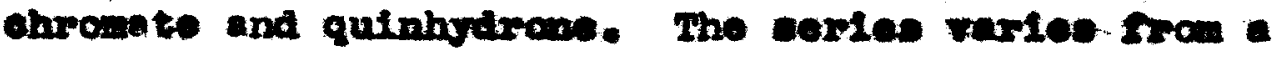
tan to a red-brom, all colore being a chade or two Carker then those listed in the ohart. Inowe wae no dofins to broak in color at any point croopt arrohadee. 
Tablo vi.

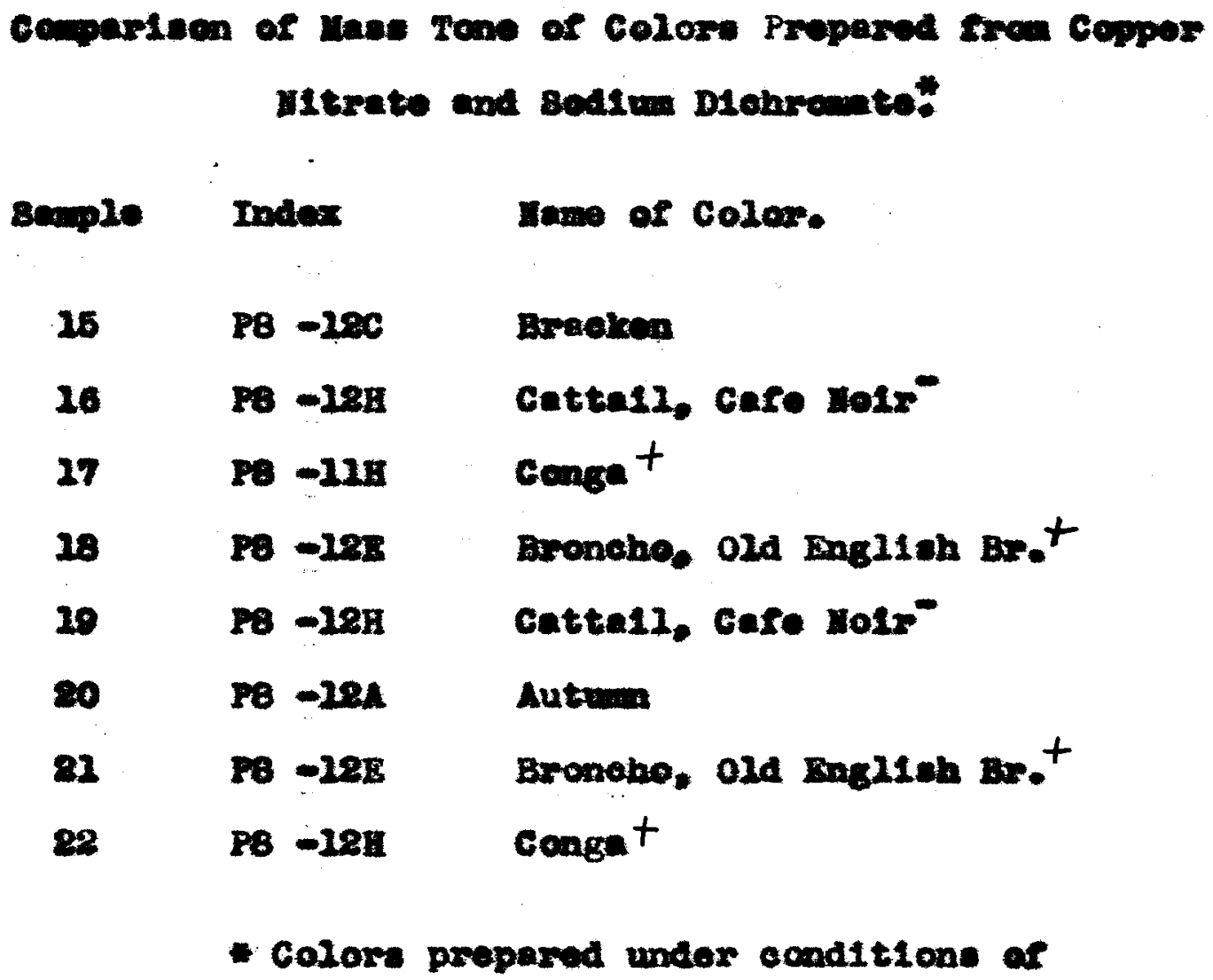

rable I.

This corien was very constant with no dofinite break at any polnt. 111 colore vore a difty greon-brom, with no partieular orfahades excopt Iumber 20 was a 11ttlo derber and llumbor 22 was a 11ttle 11ghter then othare. Huber 15 man a nore alstinot greon than any othor. Tho colore ware all alfrerint but not so dietinetis different as those in the preeoding group (Table III). 


\section{coler chers 8.}

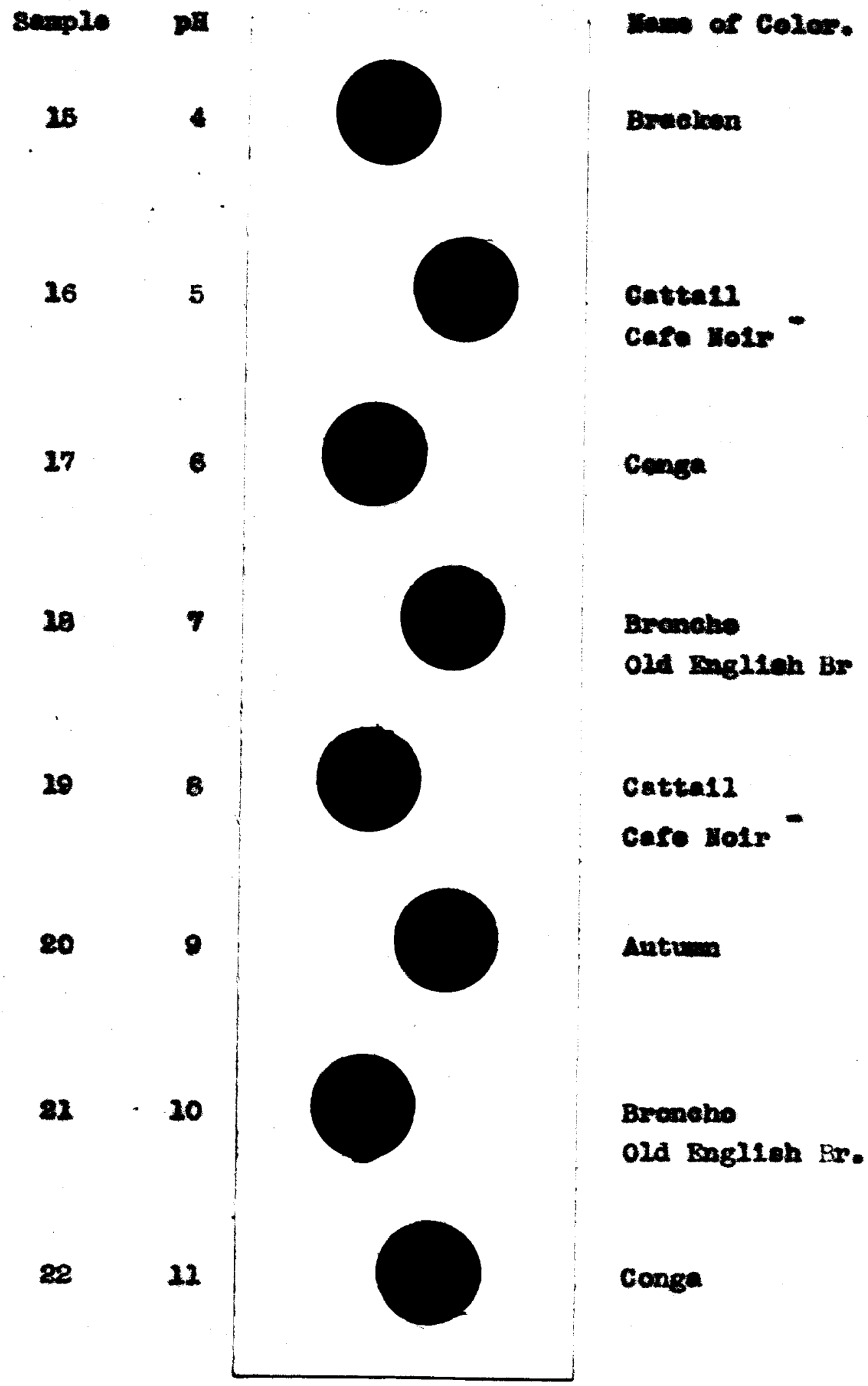


2abio vrx.

Effeet of Variation of Brdrogen Ion Ceneontration of Copper Mitrate Solntion with Hitrie Aold and sellin Brorolde. (Coppor nitrate added to modirm dichromato")

\begin{tabular}{|c|c|c|c|c|}
\hline ans & 28 & & & Remarico. \\
\hline 28 & $\mathbf{2}$ & -.490 & .5 & seluble \\
\hline 24 & 8 & $-.30 \% 8$ & 2.0 & s2leint ppt \\
\hline 25 & 3 & -.3710 & 2.4: & 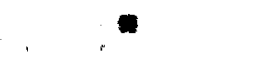 \\
\hline 80 & 4 & -.3540 & 1.7 & roalive ppt. \\
\hline 87 & 5 & -.3000 & 2.1 & Large ppt. \\
\hline 28 & 6 & -.3000 & 2.6 & $\bullet$ \\
\hline$\infty$ & 7 & -28045 & 8.0 & - \\
\hline 30 & 8 & -.2467 & 8.5 & $\bullet$ \\
\hline 81 & 9 & -.8297 & 4.0 & - \\
\hline 38 & 10 & -.2075 & 4.8 & - \\
\hline 38 & 11 & -.1108 & 5.7 & - \\
\hline
\end{tabular}

The pII of the cedive didhremate $\mathbf{8 . 6}$

This ceries is very comparable to the somies produeed in reble I. In quantity of proespitate and the pH of the solution oontaining the preelpitated color. 
rable vax.

Comparisen of Pulp Celore Propared from Ceppor Hitrite and sodie Dehromate.

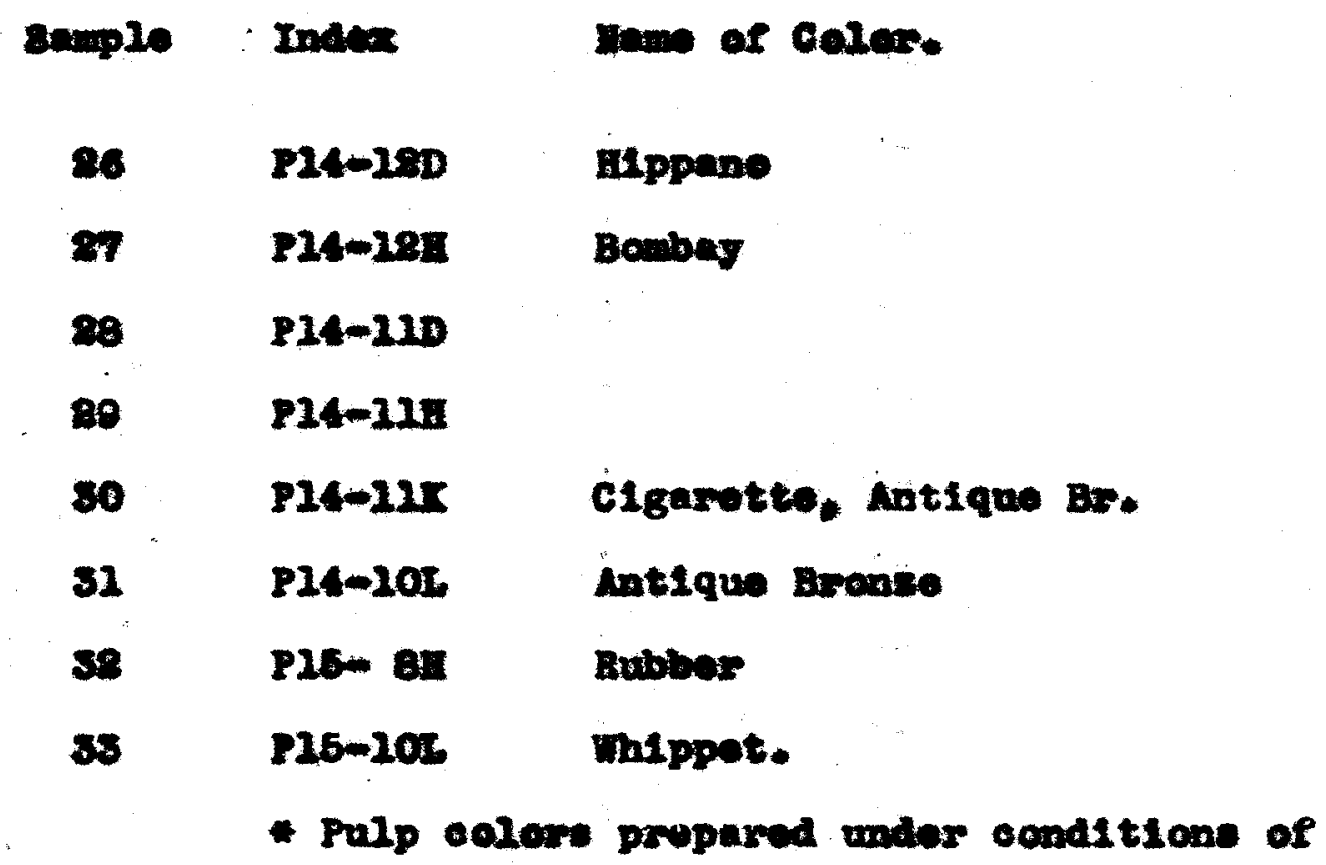

Toble VIr.

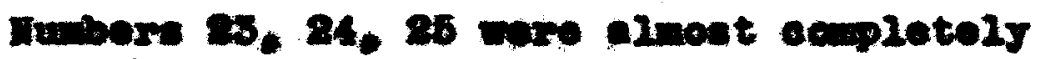
coluble so were not cenaldered in the color ohart. The comes runs from a zoddish brown (Ho, 26) to

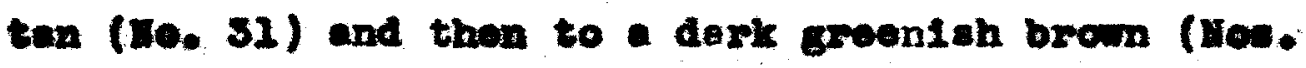
38 - 35). 8em colore were a ahnde or two darker than the corrosponding color in the chart. Thore is a derinite beak in the series at the pH of 9 (Ro, 31 ). ath no particular orfehades. The colors showed the chometerlet10 oolor ohenge whore in contact with the opporatent 12quid. 
Tabie I.

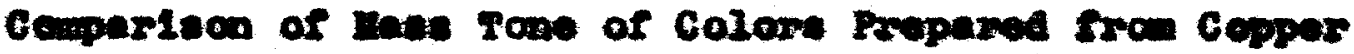
Mtrate and Solim Diahromete.

8ample Index Home celor.

2B PZO- an

26 P25- en

27 P25- 9H

$29 \quad P$ 8 $19:$

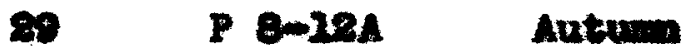

30 F25- 8L

32 P25- et

32 P15- 82.

33 P25- aL

* Colore propared under conditions of

Table VII.

The series of colere varien elightly $5 \mathrm{rem}$

- groen-brom (10. 25) to a Iight brom (Hos. 26me7)

then to a dark brom (100. 28 - 29) and tho last colore we ilght greeniah brown (How. $30-33$ ). A12 the ohanges wore distinot and rery pronounced. This nertes of colors are very comparable to thone disonsed under rable III. Tho ohenges wore at appreafmately the eam pl but the colore at any partioular pH did not mateh. 


\section{Co2or Ghart 3}

8ample pH Ham of Color.

25

3.

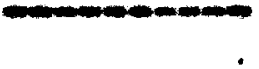

26

4

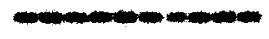

27

5

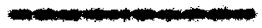

88

6

Cattall

care Hosr -

29

7

Autuma

30

B

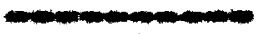

31

9

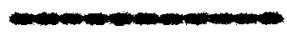

38

10

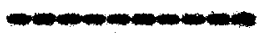

33

21

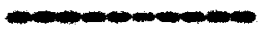




\section{Oanoral Comparisan of Colors Produoed}

Srow Coppor Hitrate.

The pulp colore of these proelpitates are

all brown or green-broms. The method of etriklng soemingly hed little effect on the color olnoe the two series of colore produced by soverse wothode of etriking (Tablos II and VIII) are very simliar. The colors compered in rables II and VIII ramed apprexImately the akmo from brom to a green-brom at the seme $p$ fl raluse. The pulp colore in the othar serles whor the pII of tho dichromate colution wes rarled were very different from the other two werlen. These wore mostly rede or red-browne with $11 t$ tie change at the various pH velues.

The wethod of atriking had little effoct on the wase tone of the difforent presipitated. The wase tones of Tables III and IX (roveree wethod of striking copper nitrate solutione) were rory comparable, although the individual colore at any parm tieular pll wero not ledentieal. The serles we whole rarled from a brown to groen-brown, belng nearly elmilar at $p H$ of $\theta$ end 20. The other serles of colore (Teble VI) was very constant with no definite breake at eny point, nor eny orfahodes. 


\section{srutra cenoung}




\section{8sirer Chromete.}

S1Lver ohremate hes been proparoa in ceveral waye. I. H. Vauguelin (3) formd that the whod of etrilding comeentrated solutions formod difforent oolowed preiopitates. When the ohromente colution was dropped into the aliver nitrate solution a reddioh brow prolepitate formod while tho mevoree wethod of atriking formod an arange red proelpitete whioh was conteminated with the potaselv selt. S12ver ohromate has almo boen propared from allver axide and potasalun ahromate, allver efrbonate and chroule axide. eliver actde and potas-

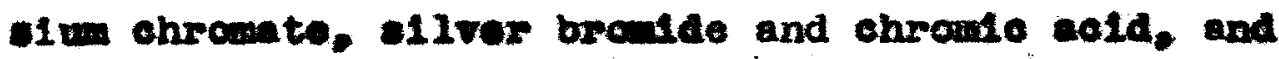
sliver diohromate. The normal silver dichrowate wae propared by H. Hoser (36) from obrople actd and oliver nitrate.

silver ohromate veries in colar with the way of proparation. R. Funt belloved thet diehrom wate solution exposed to sunlight caused the vamation of color. F. Bush (5) found the time of proolpitation of the color produced different colose. C. Frease (6) and othere found that if the 11ver salt was in excess whon the ohromete was produced 
Iren a Ilver salt and a chromate, the rod varlety was produesd, and the reoult wea not afreated by temperature. Oa the other hend when allver diahromate was decomposed by hot or cold water or when a colution of silver chromate or diolmonate wes ovaparwted severel observers heve found that groen oyratels waxe forwod. F. Kohler (7) found that the pure allver ehromete was greonlobmbleok but tho selld took in nitrates of elthor potaseive or andonivm. and In each oese the color was red. He therefore atchbuted the oolor to Imparition in the salld. It is Interesting that the opeolf1e grevity of the difforent oolored ellver onrewate varies bolng 5.656 for the green and 5.623 for the red rariety. 
Tablo $\mathrm{X}$.

Iffeat of Vametion of Hydrogen Ion Concentretion of Solim Diohrosato Solutions with Nitrie Aold and sodivm Hyarate. (S1iver nitrate" odded to sodiun dichtente.)

\begin{tabular}{|c|c|c|c|}
\hline Seaplo & pH & Ixaen: & Aonatios \\
\hline 34 & $\mathbf{z}$ & Orromate & s21gut ppt \\
\hline 35 & 2 & 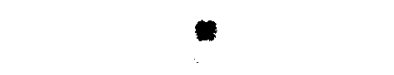 & ualtwe ppt \\
\hline 36 & 3 & $\bullet$ & $\mathbf{\bullet}$ \\
\hline 37 & 4 & 811ver I1trato & - \\
\hline 38 & 5 & 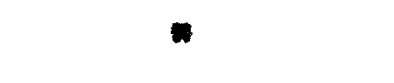 & Inve ppt. \\
\hline 50 & 6 & $\bullet$ & $=$ \\
\hline 40 & 7 & $\bullet$ & $\bullet$ \\
\hline 42 & 8 & - & $\bullet$ \\
\hline 49 & 9 & 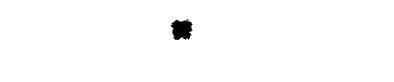 & 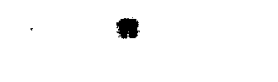 \\
\hline 48 & 10 & 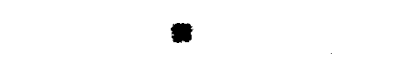 & $\bullet$ \\
\hline 4 & 21 & - & - \\
\hline
\end{tabular}

- It was Iound impossible to datermine tho pll of ollver nitrate eolutions with the quinhydrone eleotrode, se the $\mathrm{pH}$ of the diehromate was raried and the ellver nitrete beld conotent. The tim of atriking was 25 seconde. 
Tab10 XI*

Comparison of Pulp Colore Propared Irom SLIver Nitrato and Sedium DLomromte:

Sample Index name of Color.

\begin{tabular}{|c|c|c|}
\hline 34 & $P 7-7 L$ & Nerecen \\
\hline 35 & P6 - 101 & Cube , Halzezoner. \\
\hline 36 & $P 6-13 L$ & Bgrptien R* Alousar \\
\hline 37 & $P 6-12 L$ & Indien Red. \\
\hline 38 & $P 6-21 x$ & Kobo \\
\hline 30 & P7 - $10 \mathrm{~L}$ & Bottlodrum, Mansenite. \\
\hline 40 & $P 7-\boldsymbol{Q L}$ & Kosek, Capt10 \\
\hline 41 & $P B-4 L$ & Andon: \\
\hline 42 & $p q-117$ & Cordora, Castillon \\
\hline 43 & $p 7-\boldsymbol{\theta L}$ & Kosale, Gapt1e \\
\hline 4 & $F 7-2 L$ & Mazaye. \\
\hline
\end{tabular}

Tabie $\mathbf{x}$

The sertes of color:s runs from a reldishpurplo at 34 to rede. then to roddieh-broms. There 1. a definite brook at pH of 8 (No. 41) frem a to a redaloh-brown. The cerles is remible, heving a Iight peak at pl of 4 (No. 37 ) and pH 7 (10. 10). 
Table XII.

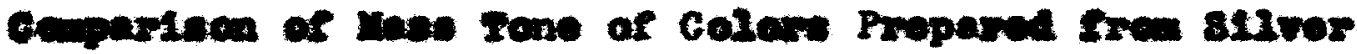
nitrate an sodiu mohrente:

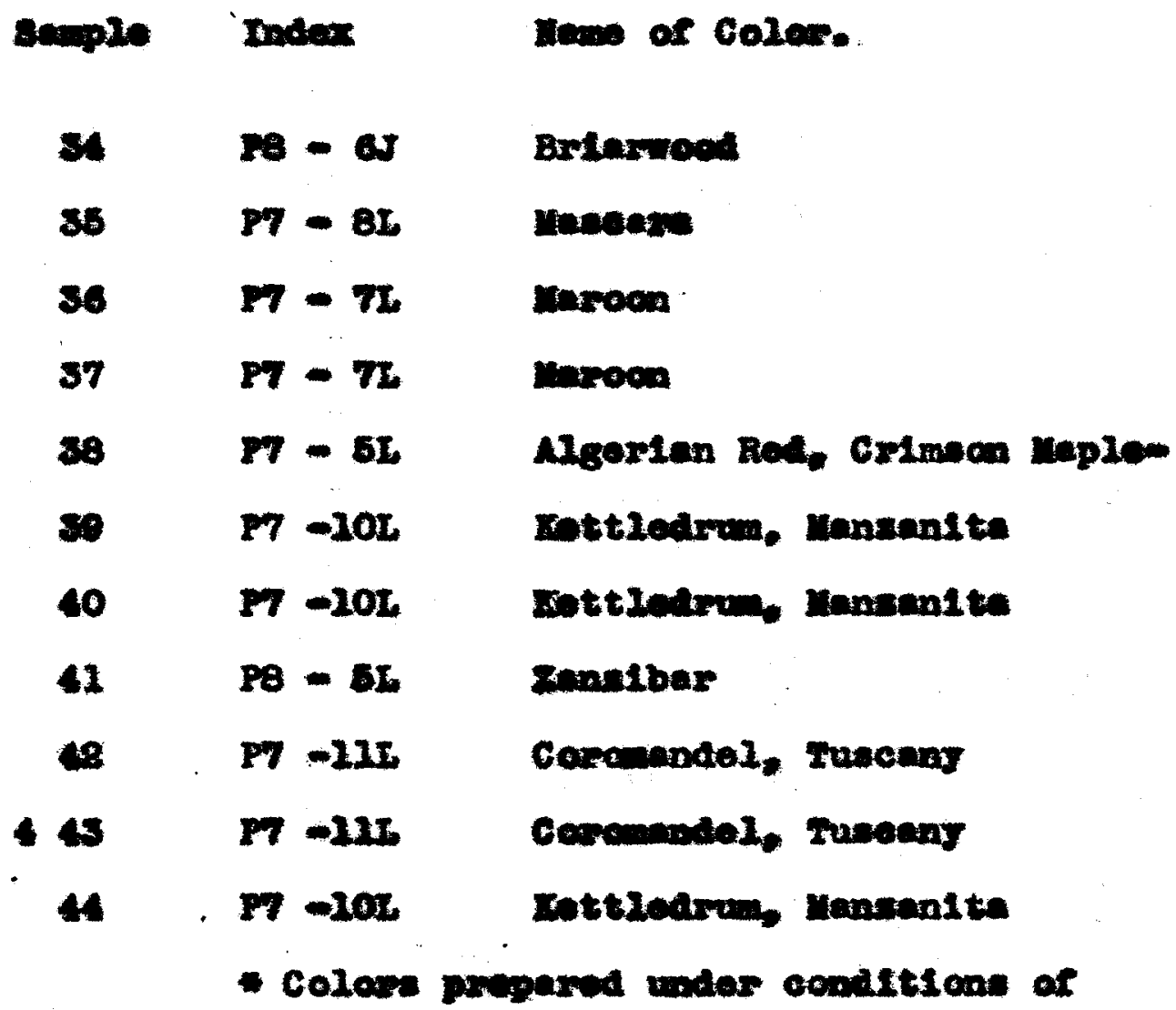

Table $x$.

This sorles of eolore wore all rede varying ond alight17. How. 4 and 41 wom offohndes wile ne. 38 wa a I1tt2 lighter then the other rede. 
Golor Ghast 4.

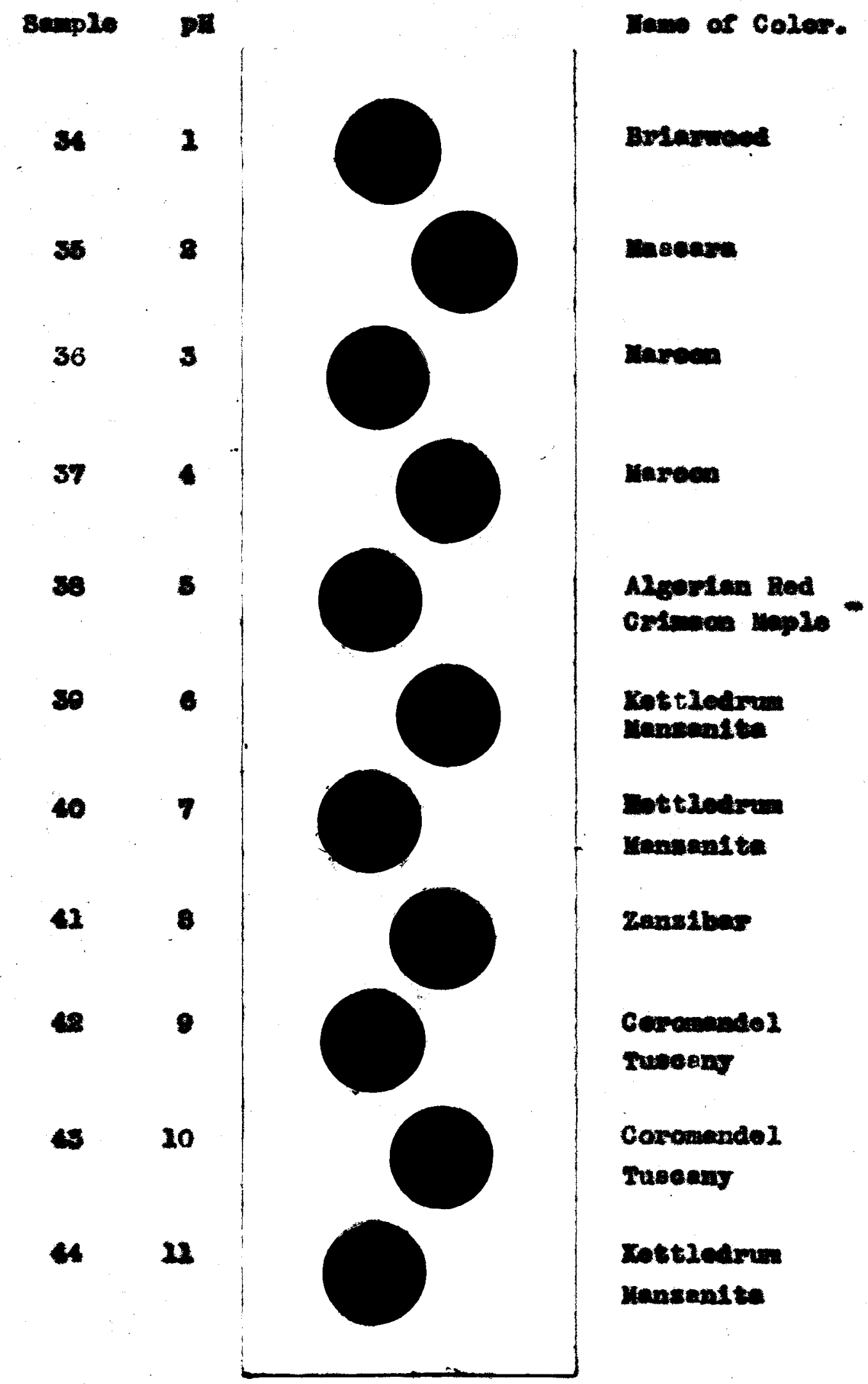


Tab2e XIII.

Exfest of Varlation of Hydrogen Ion Concentretion of Soliu Diohramate solutions with Mitrie leld and sedim tydromide. (Sedim Diohremate added te silver attrete:)

\begin{tabular}{|c|c|c|c|}
\hline anple & pA & Ixcoean & Remarice. \\
\hline 45 & 2 & Chromate & 811gut ppt. \\
\hline 46 & $\mathbf{2}$ & 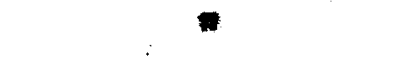 & redim ppt. \\
\hline 47 & 8 & 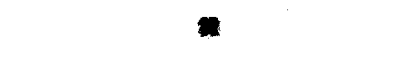 & $\bullet$ \\
\hline 48 & 4 & s11ver Mitrato & $*$ \\
\hline 49 & 5 & * & Large ppt. \\
\hline 50 & 6 & 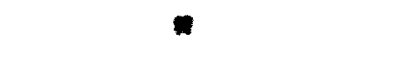 & $\bullet$ \\
\hline 52 & 7 & * & 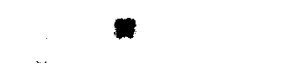 \\
\hline 68 & $\mathbf{8}$ & $=$ & $*$ \\
\hline 58 & 0 & - & 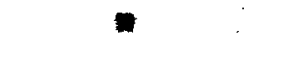 \\
\hline 54 & 10 & * & " \\
\hline 86 & 11 & 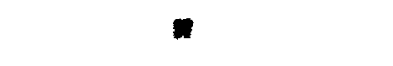 & $\bullet$ \\
\hline
\end{tabular}

the pH of aliver nitrate colution: with the quinurdrone eleotrode, the pH of the sodium diehromate we raried, and that of the eliver nitrate bold constant. 
sable XIV.

Coupariaon of Pulp Colore Prepared from Sliver Mitrate and Sodiug Dlobramate.

\begin{tabular}{|c|c|c|}
\hline Samp 20 & Index & Heme of Color. \\
\hline 45 & $P B-64$ & - \\
\hline 46 & $P B-68$ & Rowe Ebons \\
\hline 47 & $P B-6 J$ & Garnet . Spondeh the \\
\hline 48 & $P 6-221$ & Egrptien R.: Aleasax. \\
\hline 49 & $P \eta-O L$ & rasal, Coptie \\
\hline 60 & P7 - $20 \mathrm{x}$ & Kottledrux, Wancentta. \\
\hline 51 & $P 6-21 L$ & Egyptien Ro, Mleazar. \\
\hline 58 & $P 7-11$ & Inlagn \\
\hline 63 & $P 7-18 \pi$ & Chutas \\
\hline 54 & $P B-O r$ & Meraosibo, Demingo Brown \\
\hline 85 & $P 7=4 I$ & Albar- \\
\hline
\end{tabular}

rable XIII.

This series of colors zuns srom e derk purple (No, 45) to a ned (No. 5I) thon to a rod brown. Thase is a derinf te break at pH of 8 (No. 52) to a Ind brow. The weries is variable having a light pak ot pH of $4(10,48)$ and pH of 7 (no, 51). 
Iabie xv.

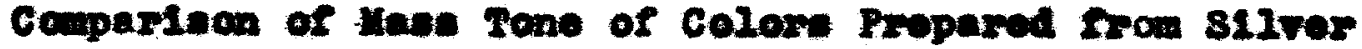
IItrete and sodium Diohromate.

\begin{tabular}{|c|c|c|}
\hline anple & Inter & Name of color \\
\hline 45 & $P B-6 J$ & Brierwood - \\
\hline 46 & $P 7-7 L$ & Unmeon \\
\hline 47 & $P 7-211$ & Corromandel, Tueceny \\
\hline 48 & $P 7-O L$ & Kosek. Captie \\
\hline 48 & $p 7-7 x$ & Eroon \\
\hline 50 & $P B-9 L$ & Larada1bo, Domingo Bromm- \\
\hline 51 & $P 8-7 L$ & Carbunsle \\
\hline 62 & $P B-7$ & Cerbunsie \\
\hline 55 & $P 7=22 L$ & Corcmendel, Tusouny \\
\hline 54 & $P B-7 L$ & Carbunc10 \\
\hline 55 & $\mathrm{PQ}-\boldsymbol{6}$ & Miredor, Art Brom \\
\hline
\end{tabular}

Table XII.

This serles of colore were $a l l$ mede. Hos. 46 and 46 mere a little darker than othere, whle How. 51 and 52 had alight brown tint. There were no definite breaks or arfshades. 
Coler Chart 5.

souple pl baw of color.

45

1 Brlarwoad -

46

$\mathbf{8}$

Iinxoen

47

3

Coxonandis 1

Tumeany

48

4

Sosuk

Ceptie

4

8

unoon

50

6

Eareetbe Doningo Brom -

52

7

Carbumale

58

B

Cexumezo

53

9

GercmandeI

rusoeng

54

20

Carbuncle

55

12. Mirador

Art Bxema 


\section{Genoral cempertion of Colore Produea frow si2ver Iltrate.}

The two corter prodused pulp eolore rery comparablo to enoh other. At pH of 6 (I0). 30 and 50 ) the oulore produed wero exaetly the came. The neries as a vole break at the eam pI value of 8 . with corrosponding 11 ght peake at pH of 4 and 7 . The

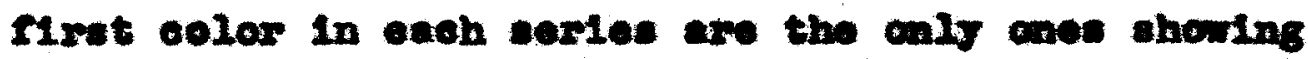
- distinet color differonoe. The wase tones were also very comparable. The mothod of atriking had 21ttie or no effect en the color produed. At pI of 1 the oolors wore creotly the same and at othor pI velwo the varietion wan alight. Ho 41 was tho only color that was dietinotiy different from the oomrenpending oolor in the other ser1en. 
-

1

MOTESTU GHROME 
Magnosive Chrenate.

Yagnenium ehromate is completely seluble

In water. (60 gram por 100 oe. $)$. The ergotale are orange-yellom six alded. Magnesivin ohrometo is propared. under a conedian patent (20). by troating - magnesiun seit with en alkall chromate. the - Irall mtal and the aeld radieal of the magnealum salt forming a more diffieulty soluble salt than the obromate. Many double ealts of mgnosive and obroming hore boen propared. 
Table XVI.

Effeet of Vartation or Hydrogen Ion Conoentration of Magnesim Hitrate solutions with Mitrie Aeld and Sodium Hydraxte. (Sodium diehremato "added to mognosibm aitrate)

Sample ${ }_{8}^{2}\left(\mathrm{mo}_{3}\right)_{8}$ (velte) $^{\text {Finad }}$

56

1

57

58

59

60

62

$\infty$

68

64

65

66

$\mathbf{2}$

3

4

5

$$
6
$$

$$
7
$$

8

9

10

11
- The pli of the sodium dichromete 2.5. Opon sotting for 12 hours Nas. 68 - 64
Romario.

Bolubie

$$
-.6200
$$

2.7

8.3

2.3

2.4

2.3

2.4

2.2

5.6

Iarge ppt.

5.4 is 


\section{carcro: Gragurs}




\section{Calelu Chromate.}

Galolu ohromet in complotely soluble

In weter (20.2 gram por 100 co.). T. Themaca (11) and $\mathrm{B}$. Wooer (36) found that a colution of calolum chloride and potaselum diohromte slowly formod a proolpitate which when analyzed by J. F. Bahr (12) was found to vary from $\mathrm{CaCrO}_{4}$ to $5 \mathrm{CaCrO} \mathrm{O}_{4} \cdot \mathrm{Z}_{2} \mathrm{CrO} \mathrm{O}_{4}$. When froe acet1e acld was present H. Tamberer (15) and F. T. Froriohe (14) observed no proolp1tato. Caloive ohromete is propared under a Canalan patent (25) by roasting an intimate mixture of finely ground forroehrom, Ilme and alkall motal saxbonate. The compound is easily converted into other ohromates and chromic seld. The besie salt he also boen propered whlch yellded lemon-yellow monoclinte priems. Lany double salts of calcium and chromium have been propared. 
Table XVII.

Bfreot of Veriation of Hyarogen Ion Conoontration of Caleiv Mitrate Solutione with Mitele sold and Sodium Hyarate. (sodiun dichromate" added to aulolum nitrate.)

sauplo

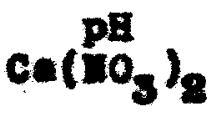

Pinal Rolin: (volte)

67

6

6

70

$\mathbf{7}$

$\boldsymbol{r}$

73

74

76

76

77
1

8

3

4

6

6

7

6

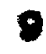

20

II

$-.2650$

$-.7200$

$-.5325$

. .4800

$-.3550$

. .3775

$-.3005$

$-.3016$

$-.2950$

$-.2950$

$-.2850$

Romarre.

pa

soluble

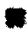

0.6

1.7

1.3

2.6

2.6

8.7

2.7

2.8

3.2

- The pll of the sedive diebromate 2.5 .

The time of atriking was 30 seconds.

Wo further Investigetion was made of this group elnce all proved to bé soluble. 
82

STROArIU Chouate 
Strontiu chronate.

Strantive obremate is proclpitated from coneentrated solution or strontio chiecile and a ohrounte. bet 3. D. Sint th (26) oboorved that no proolpitate formed in illute solutian. strontin chromte 1. not proalpitated from atrontium hrirencide. nel thar w111 it proolpltate from an ecetio esid colutica. I. Bourgools (27) obtained the eryataline selt by fusing etrontlum chloride with sodium and potesefum ohrematos. Strontium ohromate ha been uned as a plonent, and to comonit lonom as lemonjeLlon. and strontiun gellow. 
Iable XIII.

Exreat of variation of Hrirogen Ion Concentuntion of strontive Chloride Solutions wth solive

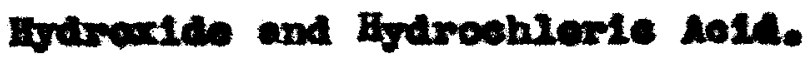
(Sedium DLohromte" added to etrantive eblecilo)

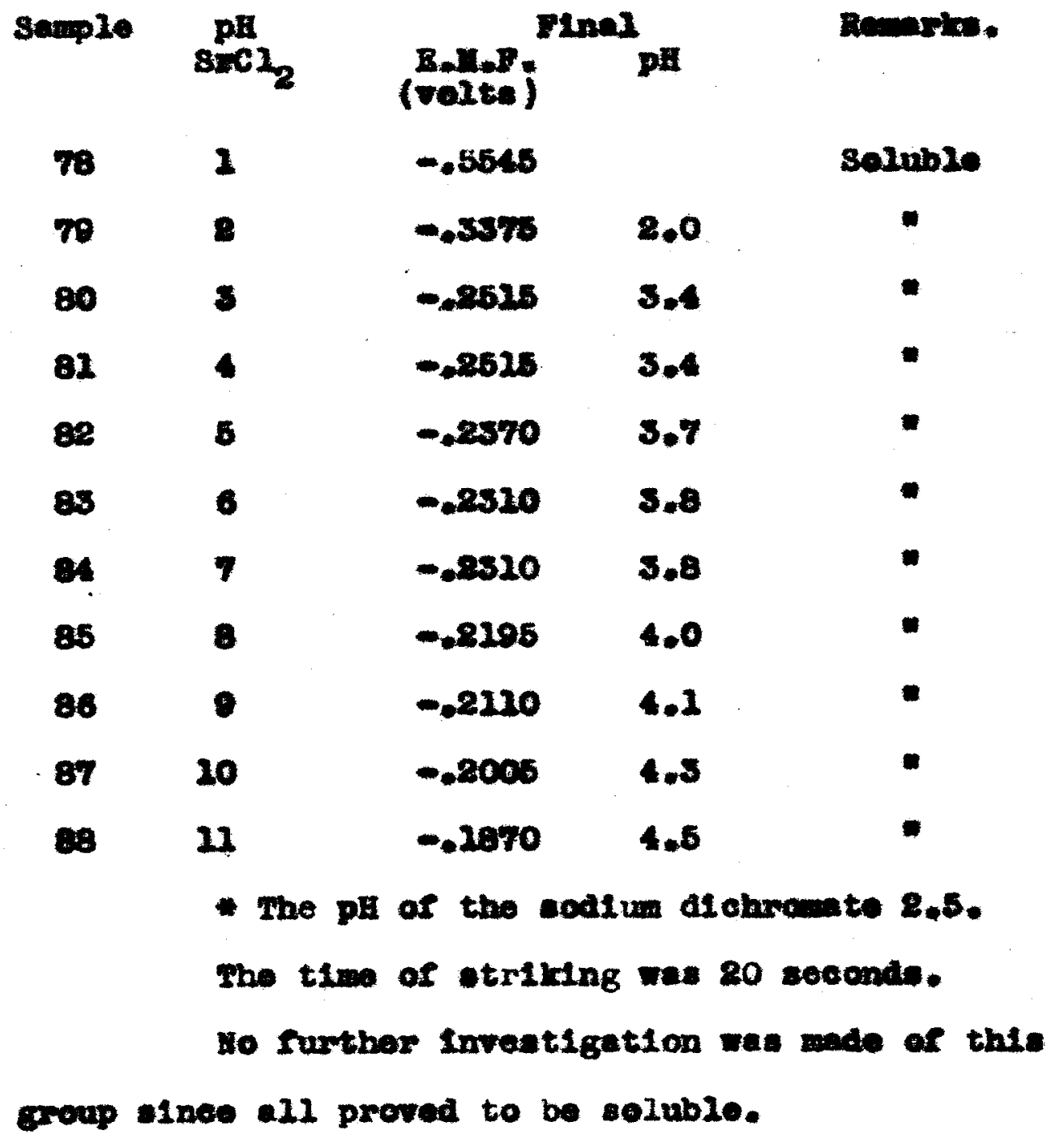




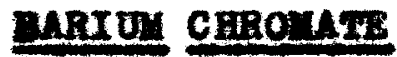




\section{Barium Chromate.}

Bartum obromate has been prepared by mony oxporimenters in many difforent prososses. When an aquous solution of a barium salt is treated Wth an elkall ohromate or alohromete, pale yellow proolpitete of barium ehromate is romod. Barium diohromate can be propered of ther from barlum chloride or barlum ohromate and concentrated chromis 101d. The dichromate decompeses to the monoehromate In oold water. Barive obrowate and berium sulphate are about equally soluble, both belng more insoluble than the carbonate. H. Yoser (36) found the pale jellow barlum ohromate changed to a dark yellon upon hoating. Barium ohromate has been used as plgmont beling commonly knom al ultramarino yeliew. lemon yellow, and permanent yellow. Severel double ealte of baxium and ohromium have been formod. 


\section{Table $x x$}

Efrest of variation of Hudrogen Ion Coneentretion of Bariv Chlories selution at solin

Hyareside and fydroohionte seld. (Sodium dichromte added to bartum ohloride)

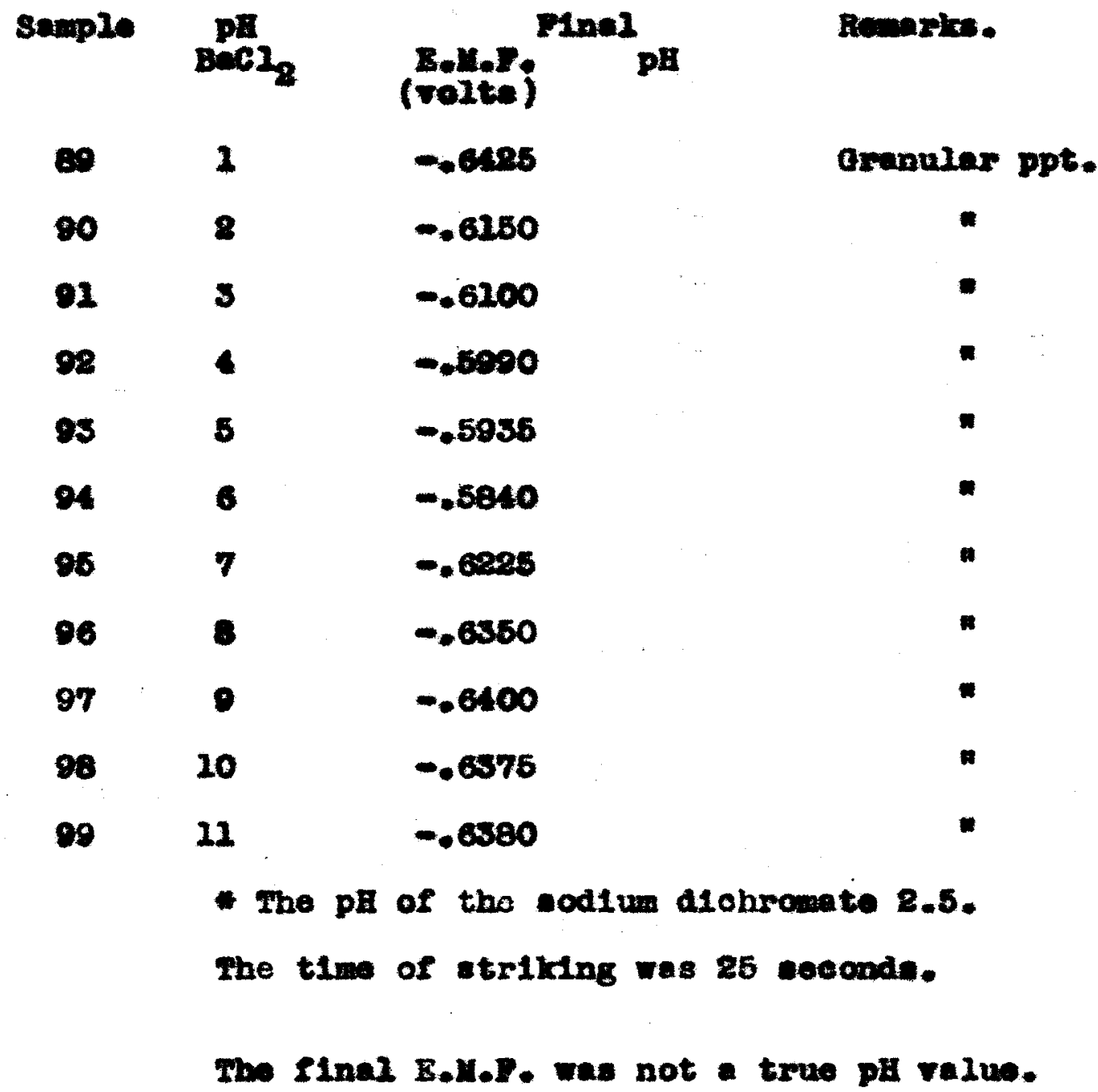


$\operatorname{son} x$

Cemparison of Pulp Colors Prepared from Barive Chloride and Bedive Dohecmate.

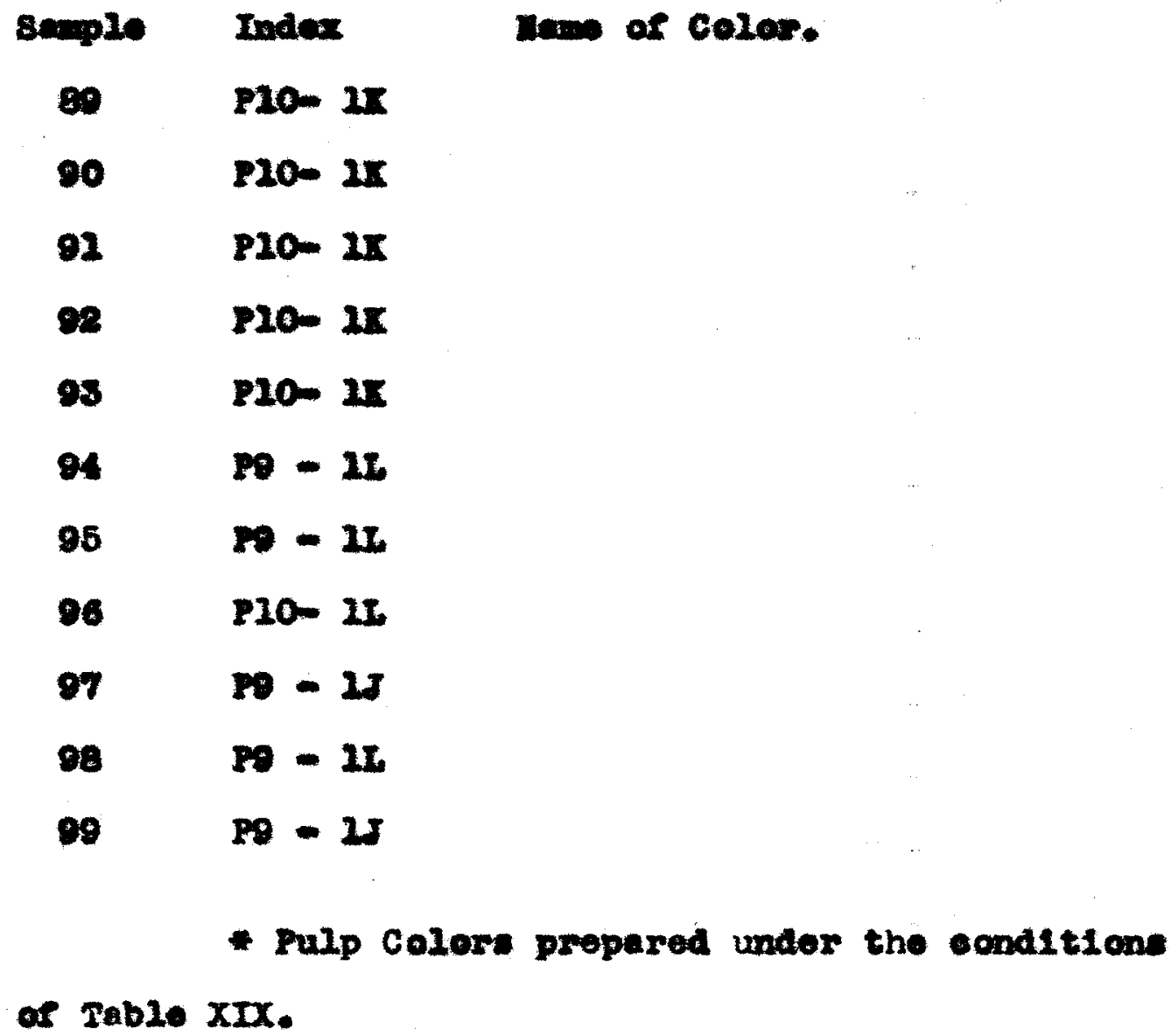

The eorles of colore variod slghtly from

- Light jellen to a darker yellom at pH of 8 (Ho. Ob) then to a 11ghter yellow. The caly brokk in the group was at the pH of 8 . 


\section{zobie xx.}

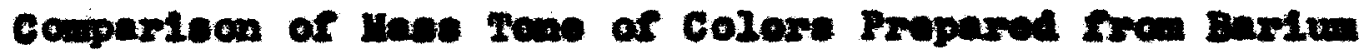

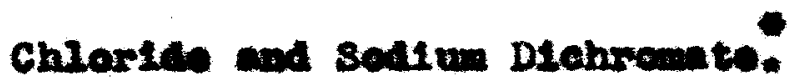

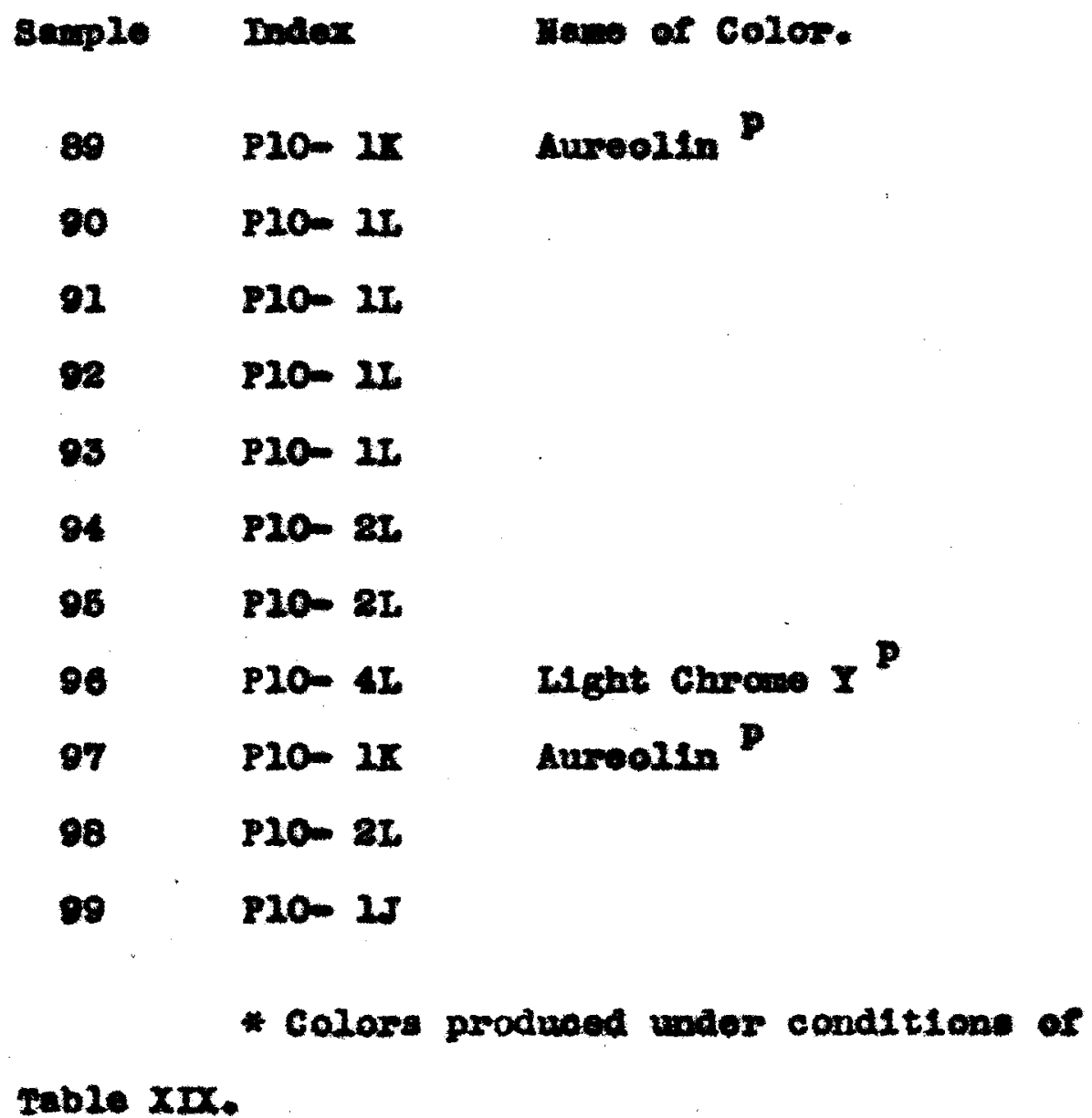

121 colare were elther yellom or aream. wos. 96 and 98 wore rellown, Hoe. 97 and 99 more a aroan, while Hos. 89 - 95 varied from a eroan to a malim rollon. 
Color chart 6.

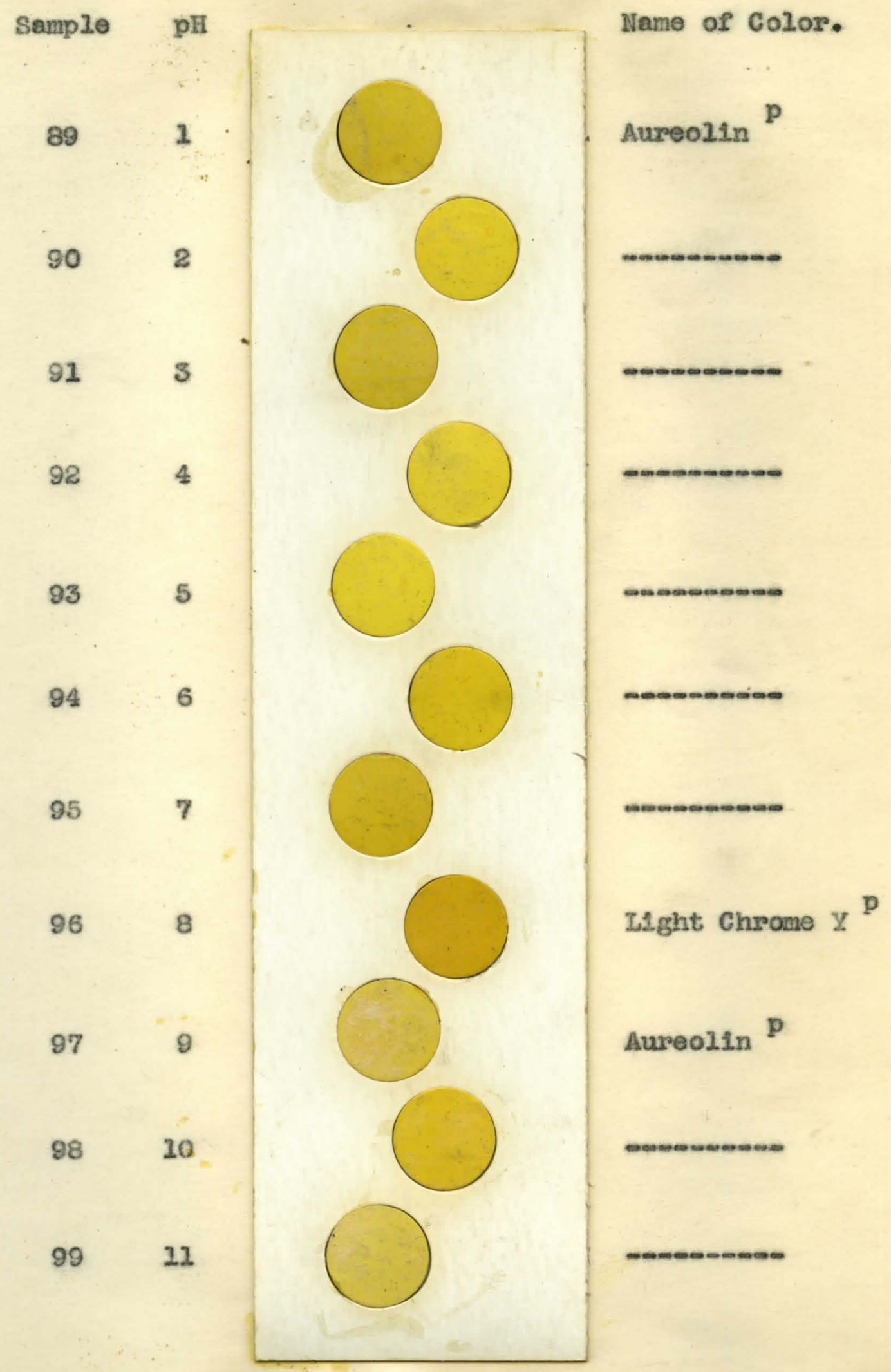


Table 2xII.

Effoet of Variation of Hrdrogen Ion Concentration of Sodiun DLehromate Solutione with Sodtu Hytroxide and Harechlorie lold. (Sodiu Alohrcuate added to barim ohlowide.)

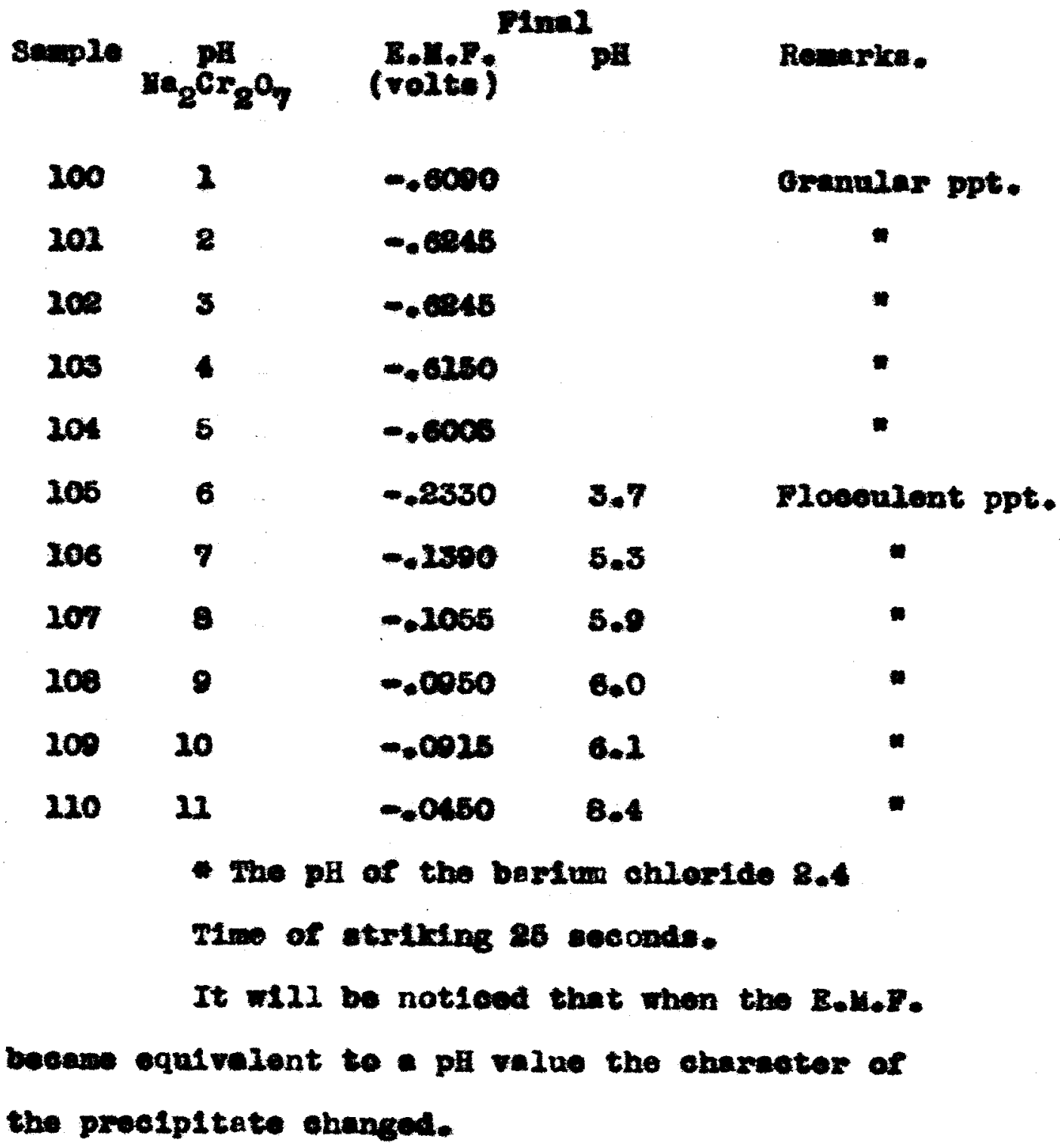




\section{Tablo XXIIT.}

Ceaparison of Pulp Colors Proparad from Barlum Chloride , and sodivi Dlohwomate.

sauple Indax Ines of color.

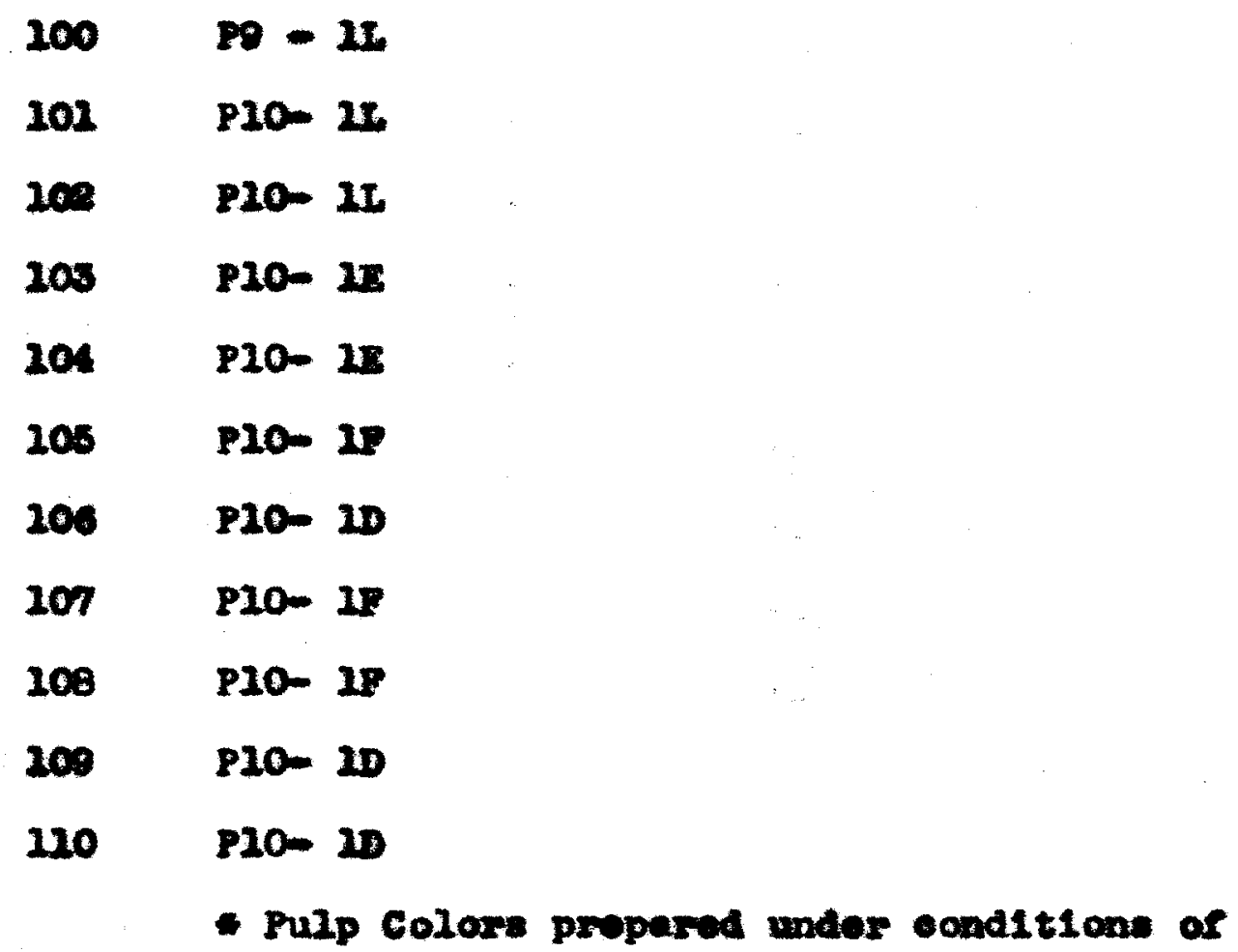
rable XXII.

Newe of the ebove colore were named in the Dictionary of color. The cerles of celors rune

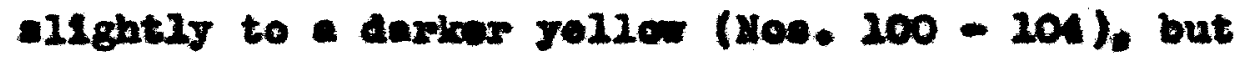
wth the ahange in the charecter of the proelpitete thow is a comrespending ohange In the color, to 
- Ilght croaz gradually beocming whter. with the riec in $p E_{\text {. }}$

\section{rab2e $20 x$}

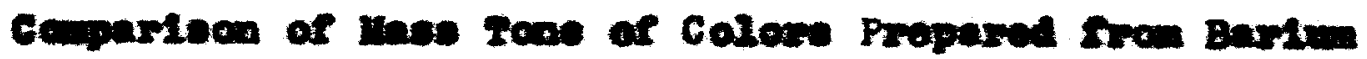

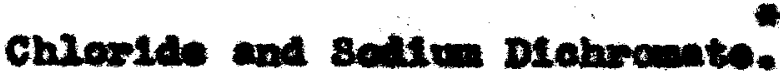

\begin{tabular}{|c|c|c|}
\hline Somple & Inder & Inme of Colar \\
\hline 200 & P10- $1 x$ & \\
\hline 108 & $220-82$ & Aureaken \\
\hline 208 & P10- 2L & Ampodsn \\
\hline 205 & $P 10-21$ & \\
\hline 204 & P1O- II & \\
\hline 185 & P10 28 & \\
\hline 106 & $810-10$ & \\
\hline 207 & $P 10=10$ & \\
\hline 108 & P10- 20 & \\
\hline 109 & $210-20$ & \\
\hline 110 & $820-10$. & \\
\hline
\end{tabular}

rable $\mathbf{x x I}$.

This sorles of colors were all jollewe or 0xoen. Hos. 100 - 102 were yellowe with 100 a l1ttie 11ghtar shede, while Hoe. 103 - 210 ware all oreans. varying only sight2y. 


\section{Color Chart 7}

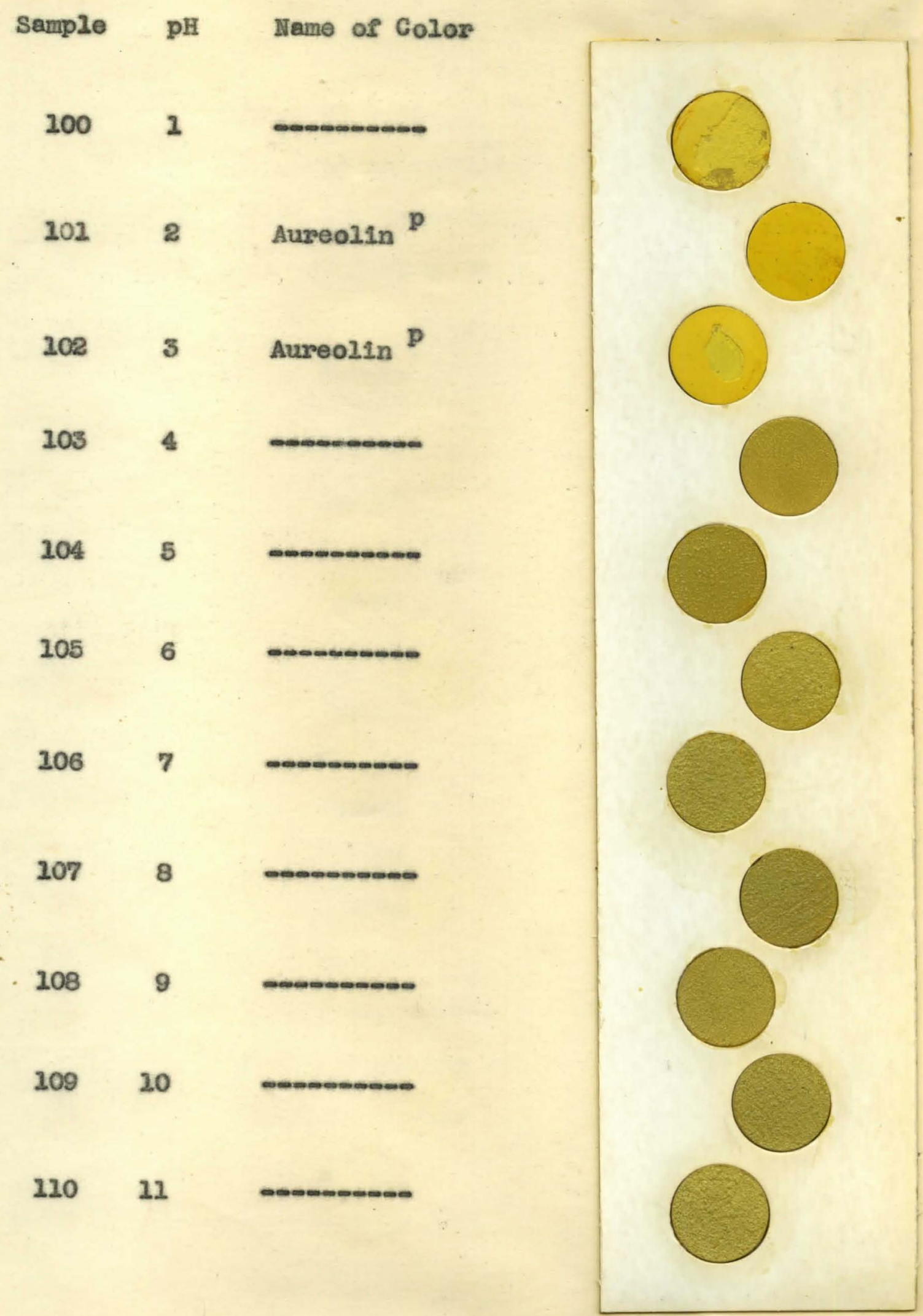


Table XxV.

Erfoet of Variation of Hydrogen Ion Concentration or Barium Chlaride Solutione with sodim

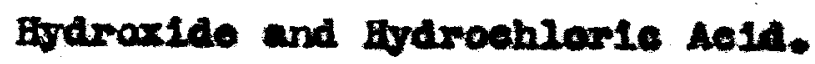
(Bartum ohloride sdad to sodium diekrometo:)

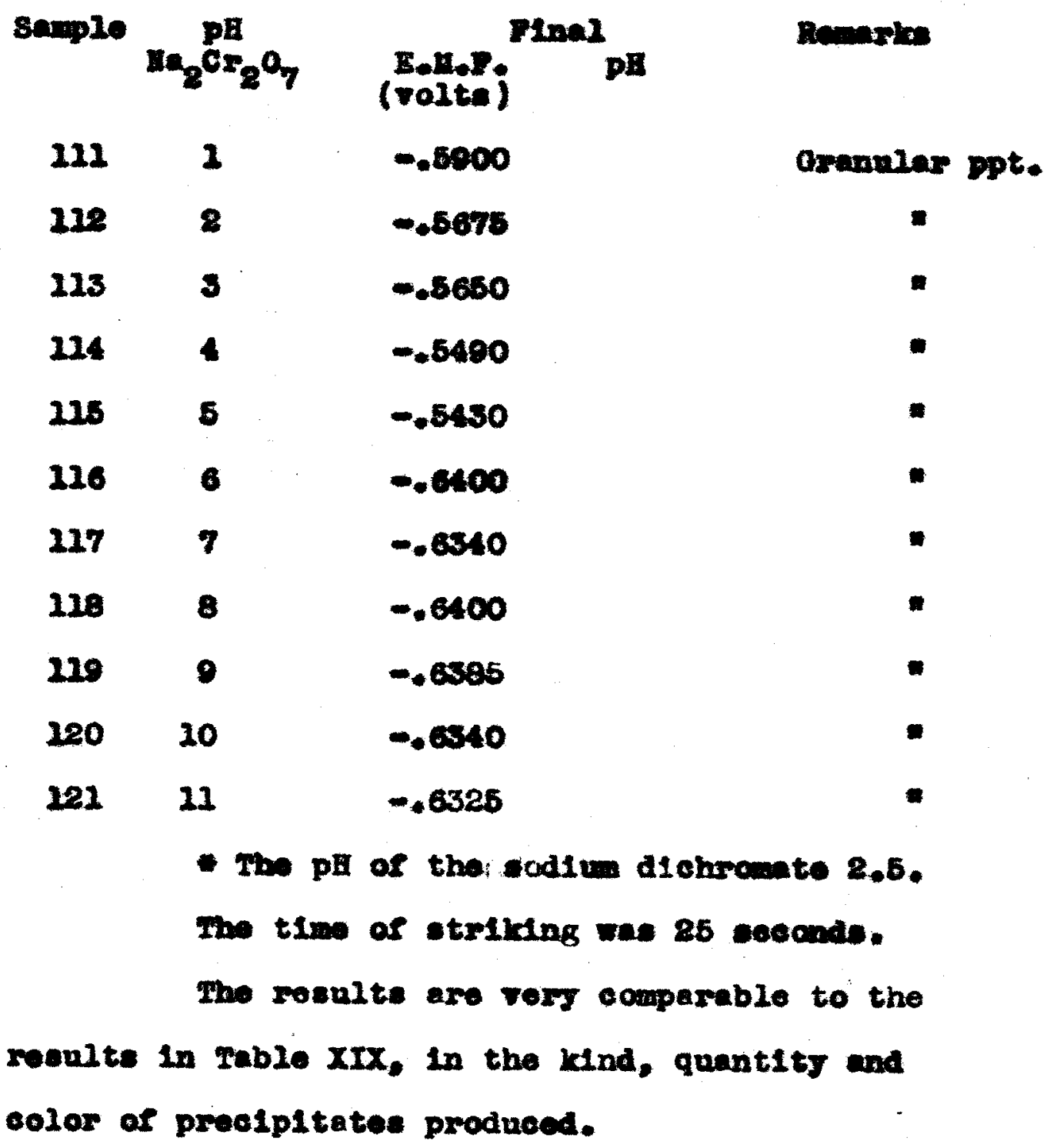




\section{Table XXVI.}

Cemparisen of Pulp Colors prepared from Bartun Chloride and Sodivin Dlohromate.

Sample Index bamo of color.

211 PIO- IR

122 P10- ir

125 P10- 21

214 P10- 21

215 P1O- 21

$126 P-2 L$

$217 \quad$ PO $-5 I$

$218 \quad \mathrm{PQ}-32$

210 PO - IX

$280 \quad P O-2 L$

$121 \quad P Q-1 \mathrm{I}$

- Pulp colore propared undor conditlons of

Table XxV.

Howe of the above colors were named in the

DLetlonery of Color. There wae very 11ttie ohange in the sories, How. 121 - 216 being precticel2y the sam. Now. 137 and 218 changed sightly to a derlor Jellow while Hos. 210 - 281 gradually ohanged to a 
arean. muber 120 (pH 10) wee on orfahnde. Tha breok in the serles wae at 118 (pH 8). Numbers 216 and 217 showed ahnge in colar whore in oontact with the oupernetent 21 quid.

\section{Table XXVII.}

Comparieon of has Tone of Colors Prepared from Barlum Chloride and sodium Diohromate.

\begin{tabular}{|c|c|c|}
\hline $\operatorname{senple}$ & Index & Rame of color \\
\hline 212 & P10- 2x & \\
\hline 112 & $810-21$ & . \\
\hline 123 & P10- 21 & \\
\hline 124 & P10- 2L & \\
\hline 125 & P10- 21 & \\
\hline 116 & $P 9-2 L$ & \\
\hline 227 & $P Q-2 I$ & \\
\hline 118 & P20- iI & Light Chrome I \\
\hline 210 & P10- $2 x$ & \\
\hline 220 & P1O- 2L & \\
\hline 281 & $210-21$ & Sulphur $Y_{\text {, C1true. }}$ \\
\hline
\end{tabular}

Table XXV.

All colors are ye lows or creams. Hos. 118 and 200 were a deopes yellow then othere whlle Hoe. 219 and 121 were areans. Hoe. 211 - 127 varied gradually from exern to a light yellow. 
Color Chart 8.

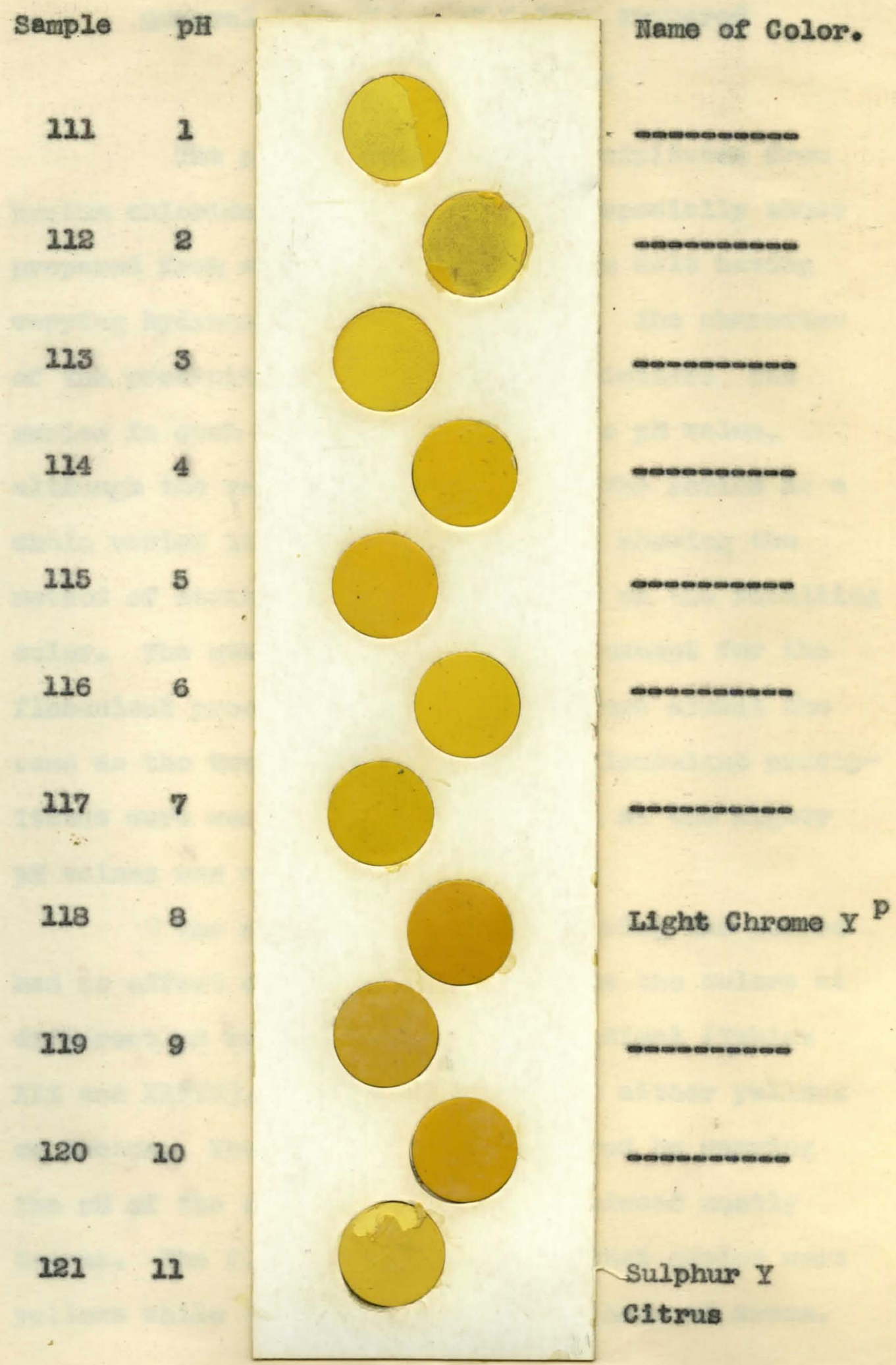




\section{Gonoral Compariten af colorw Propared Tron Barive Chrowide.}

The pulp colore of the preelpitates from

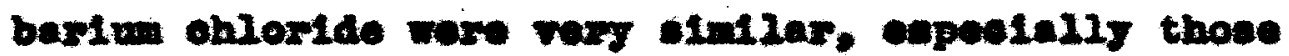
prepared from colutions of the barium esit having varying hydrogen ion ceneentrations. The charaeter of the proelpitete in each is aleo almilar. tho eorles in each sase broke at the samp pll valus. al though the variation wa allght. Ime sesied es a

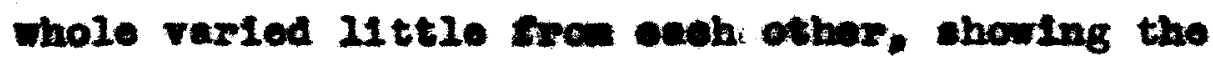
mothod of striking had 11 ttio erfoct on the rowdting coler. The othor eceice of ealors, exeopt for the Roovulent proelpitate, produon eolors alnost the sowe es the two othor eories. The rloseulent proelp1tates wow moh 11 ghter jellown and at the highor pII velvos wai alwowt whito.

The rweres mothod of strilling the colore bad no arrect on the nace tomes sinee the colore at different ph valuos were slmost lientioel (Tables XXI and XXVII). MII the colow vase alther yellew or oxeans. The other somes, propared by varying the pH of the codium dichromate, produced nootly croams. The flrst threo colors in that cerles were Jellows while the othere wore som shede of erean. 
TTA GRROUT: 


\section{Zine Chromate.}

Mermal sine chromate is not easily prepared since in concentrated solntions at high temperatures axygen is given off and in more dilute solutione the basce salt is formod. (38) soreral experimonters have howeror obtalned the normal ealt. J. Sohulse (8) doscribed it as belng lomon-yellow micracoplo oryetale, which are insolublo in water. The basie sine ohromates that form are of inderinite composition and have boen used as pigments in paints. They are commoniy called sine yellem, sine ohrowe, or yellow ultremerine. Four besic aelte of definite compostion heve been prepared by difforent exporm imenters. They ere sine triexychromate, (4Rno.CrOs"

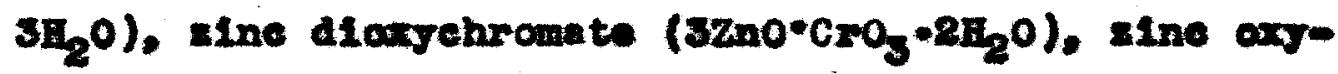
chrounte $\left(22 \mathrm{nO} \cdot \mathrm{CrO}_{3} \cdot 1+\mathrm{Z}_{2} \mathrm{O}\right)$, and zine wrolsehromate $\left(32 n 0 \cdot 2 \mathrm{CrO}_{5} \cdot \mathrm{H}_{2} \mathrm{O}\right)$. Zine obloride in on aquous solution or I. or 31. potaselum dlohromate fromed a gollow granular precipitate $\left(42 n O \cdot \mathrm{K}_{2} \mathrm{O} \cdot 4 \mathrm{CrO}_{3} \cdot 3 \mathrm{~K}_{2} \mathrm{O}\right)$ which when washed with hot wator several time was converted into a dark jellem proelp1tete $\left(\mathrm{ZnCrO}_{4} \cdot 3 \mathrm{Zn}(\mathrm{OH})_{8}\right)$. A darker preelpm 1tate 1s formod whon in excose of potaselum dichromate 1. woed than when an excess of the sine salt. 
rable XVIII.

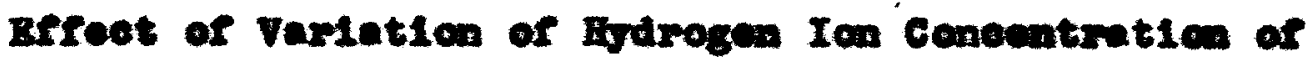
2ine Mitrate Solutione with Iitrie sald and sodiu Hrimoride. (Bodium dichromate" added to sine nitrate)

\begin{tabular}{|c|c|c|c|c|}
\hline anple & $p \mathrm{~PB}$ & & & Remarks \\
\hline 108 & 1 & -.6406 & 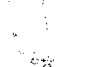 & solvible \\
\hline 123 & 8 & -.3560 & 2.7 & $\bullet$ \\
\hline 224 & 3 & -.3000 & 8.6 & $\bullet$ \\
\hline 125 & 4 & -.8500 & 3.4 & $\bullet$ \\
\hline 186 & 5 & -.2550 & 3.7 & - \\
\hline 227 & 6 & -.0000 & 4.3 & $\bullet$ \\
\hline 228 & 7 & -.1525 & 5.2 & Haty ppt. \\
\hline 129 & 8 & -.2160 & 5.7 & $\bullet$ \\
\hline 2301 & 9 & -00045 & 6.1 & $\bullet$ \\
\hline 232 & 20 & -.0045 & 6.2 & - \\
\hline 138 & 12 & -.0050 & 6.1 & - \\
\hline
\end{tabular}

All proolpitates were formed from eolution In whioh a lergo amount or basio salt was procipitated, before the addition of the sodium dichromate. 
Table XxD.

Comparieca of Pulp Colore Propared from zine HItrute and Sodive DLahromate.

\begin{tabular}{|c|c|c|}
\hline 8amplo & Index & Lome of Color \\
\hline 288 & $P 14-12 x$ & Butan Bx \\
\hline 189 & P23- 0L & Ohtpment: \\
\hline 130 & $P 14-212$ & out. Brias \\
\hline 231 & P14-10x & perin \\
\hline 132 & PL-19L & Suden Br \\
\hline
\end{tabular}

* Colore propared under conditione or Table xxIII.

Phis series of colore wore all brome. Samp 208 H08. 129 - 130 ahowed alght jollow proelpitate which wes heterogenoouels wixed in with the ark brom precipitate. 121 the preelpitate wero very rloceulent and about the same shade of brown. Io prealpitate frowed srose solutione that were not bale enough to preolpitate the hydrexide, before edding the chromate. 
Table 20.

Cemparisen of une tone of Colore Propared from 21 o ILtrete and sodiu Diobramato.

8auple Index Haw of Color.

227 PB -20J Jave . Honad Brown

228 P15-121 Burrale

129 P2s os.

230 P13-121 Burfelo

232 P23- 9L

232 P13-10R whippet

- Colore propared under conditions of

Table XXYII.

This eroup of colore were 11 soms shale of brow, varying slightiy from a groenmbrown to - modiug brom. 


\section{coler chare 9.}

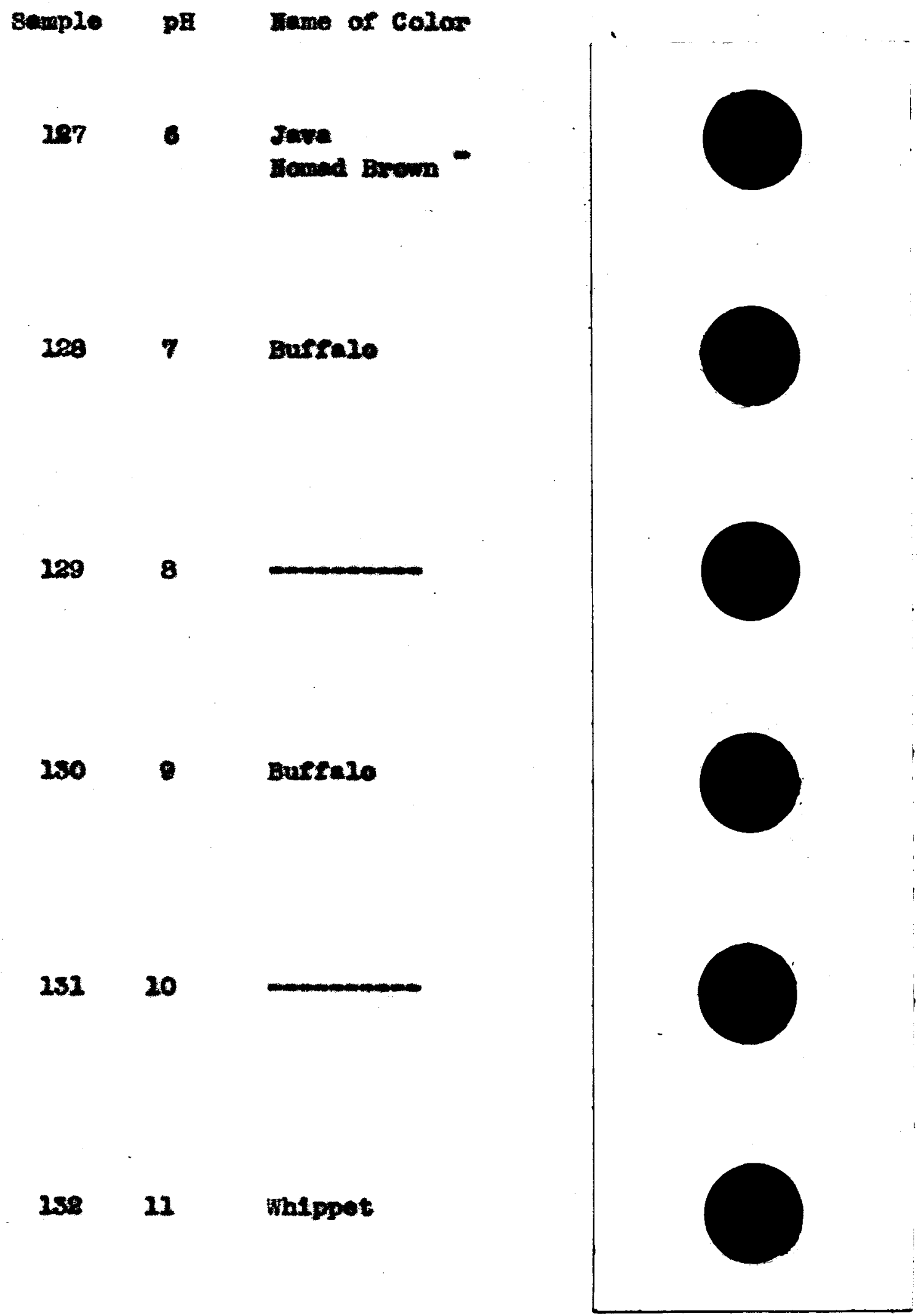


2able xex.

Effeot of Variation of Ererogen Ion Ceneontaratien of Bodiu Diebremete Seluticas with Ittole sold and sodiun prareille. (sodiun dienremte added to sine nitrate.)

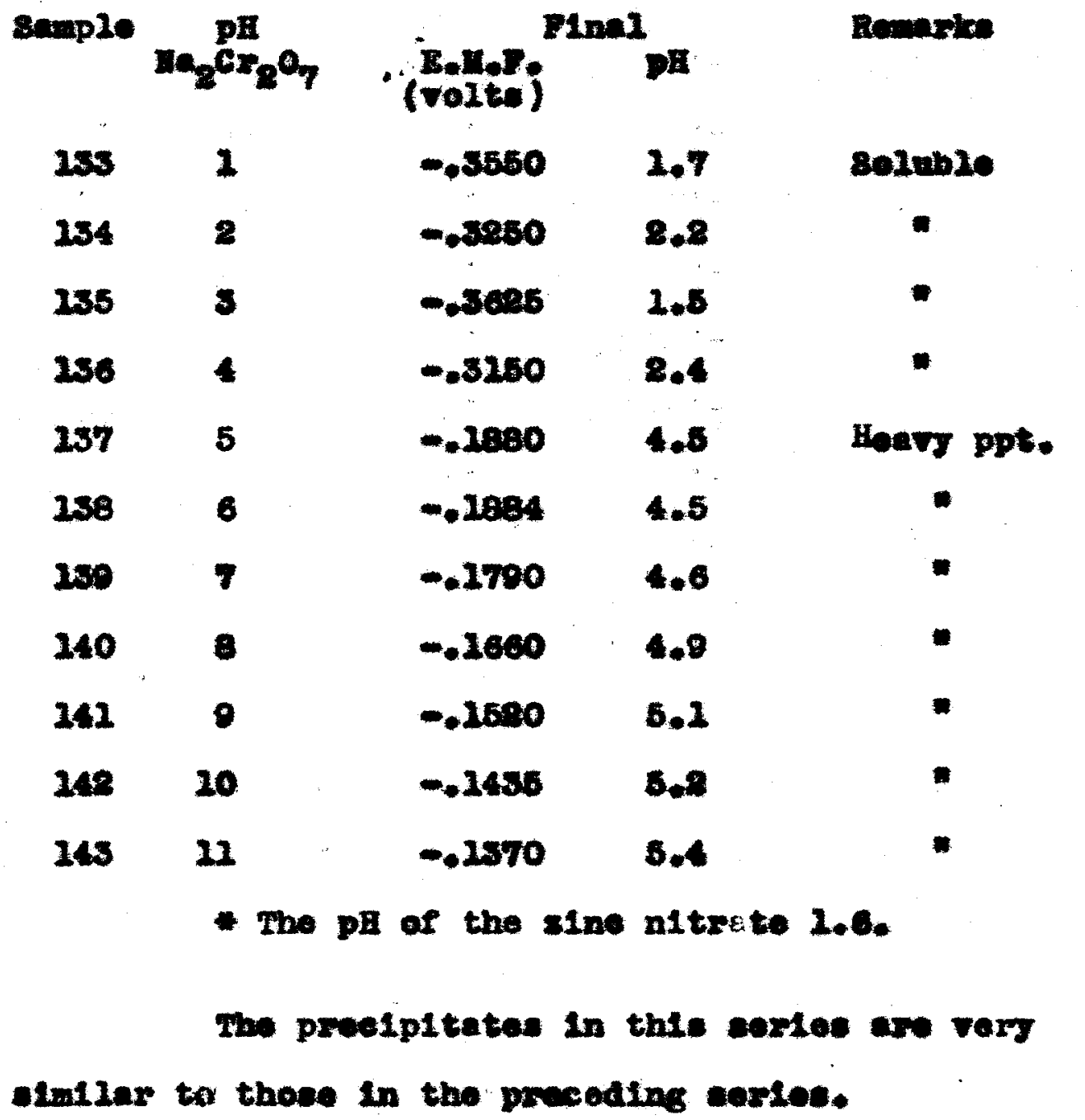




\section{0 $00 \mathrm{xI}$}

Comparison of Pulp Colore Proparod from zine mitrato and sodim DAobromate.

\begin{tabular}{|c|c|c|}
\hline $\operatorname{ang} 20$ & Index & Inm of celco \\
\hline 237 & P23- at. & Duolrthore Bx. \\
\hline 230 & P23- 8x. & Buarthora Br. \\
\hline 200 & $P 13-21 x$ & Porratan Be \\
\hline 200 & $P 28-11 x$ & Pourustan Br \\
\hline 141 & $223-100$ & Ran stomat \\
\hline 148 & P13-10L & Rur steme ? \\
\hline 216 & P23-102 & Raw sicane \\
\hline
\end{tabular}

- Pulp eolori propared under conditiono of Table xwa.

This ceries of colore we very constent,

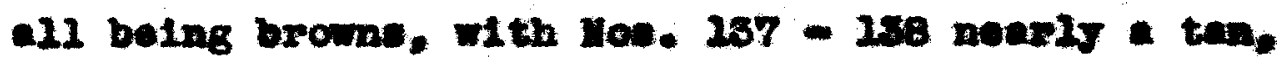
and 100.230 - 140 dark brome while ves. $142-143$

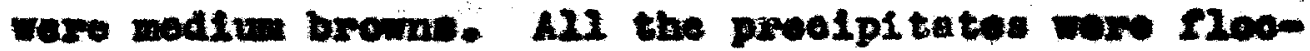
oulent imilar to those in rable xx. 
Tabie xaIII.

Comparisca of lase Tone of Colors Preperwa from zino Hitrate and Sodium Diobromate.

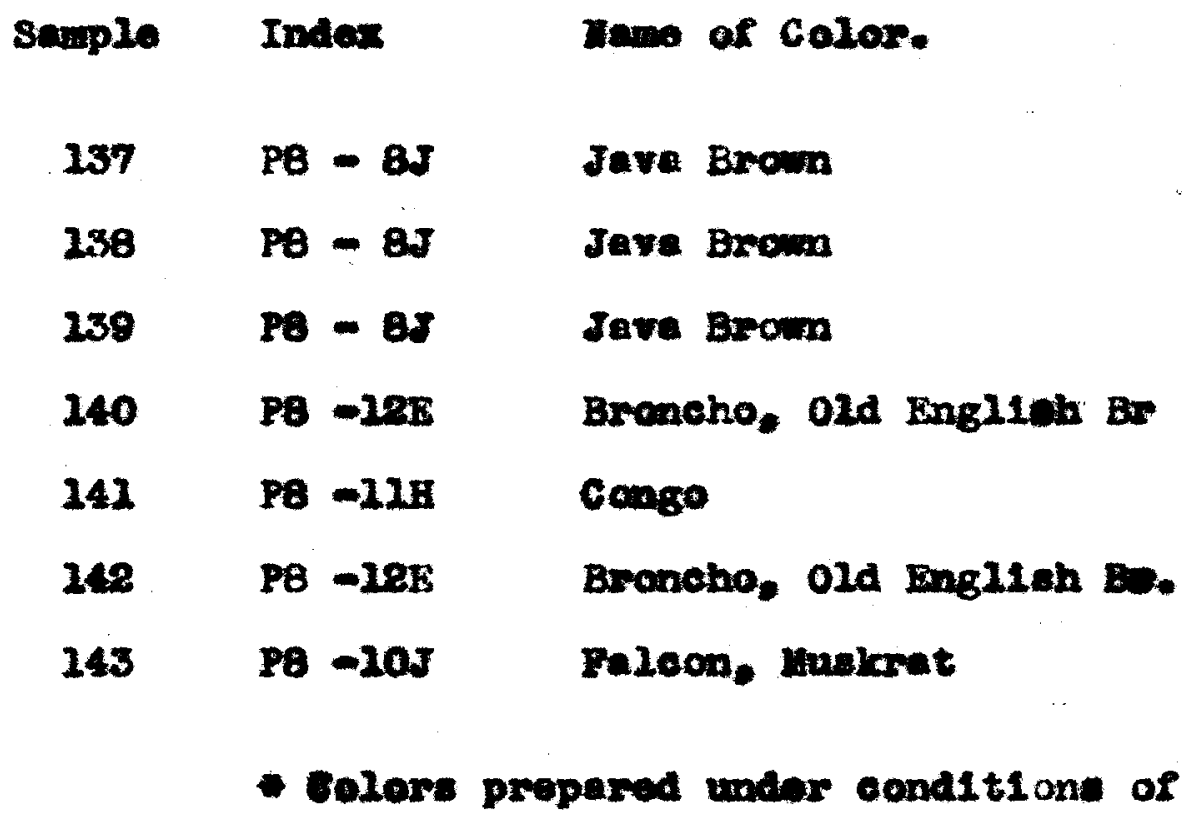

Table xxx.

This group of colore varied only olightly. 11 colore belng a modium brown. 


\section{Coler chart 10.}

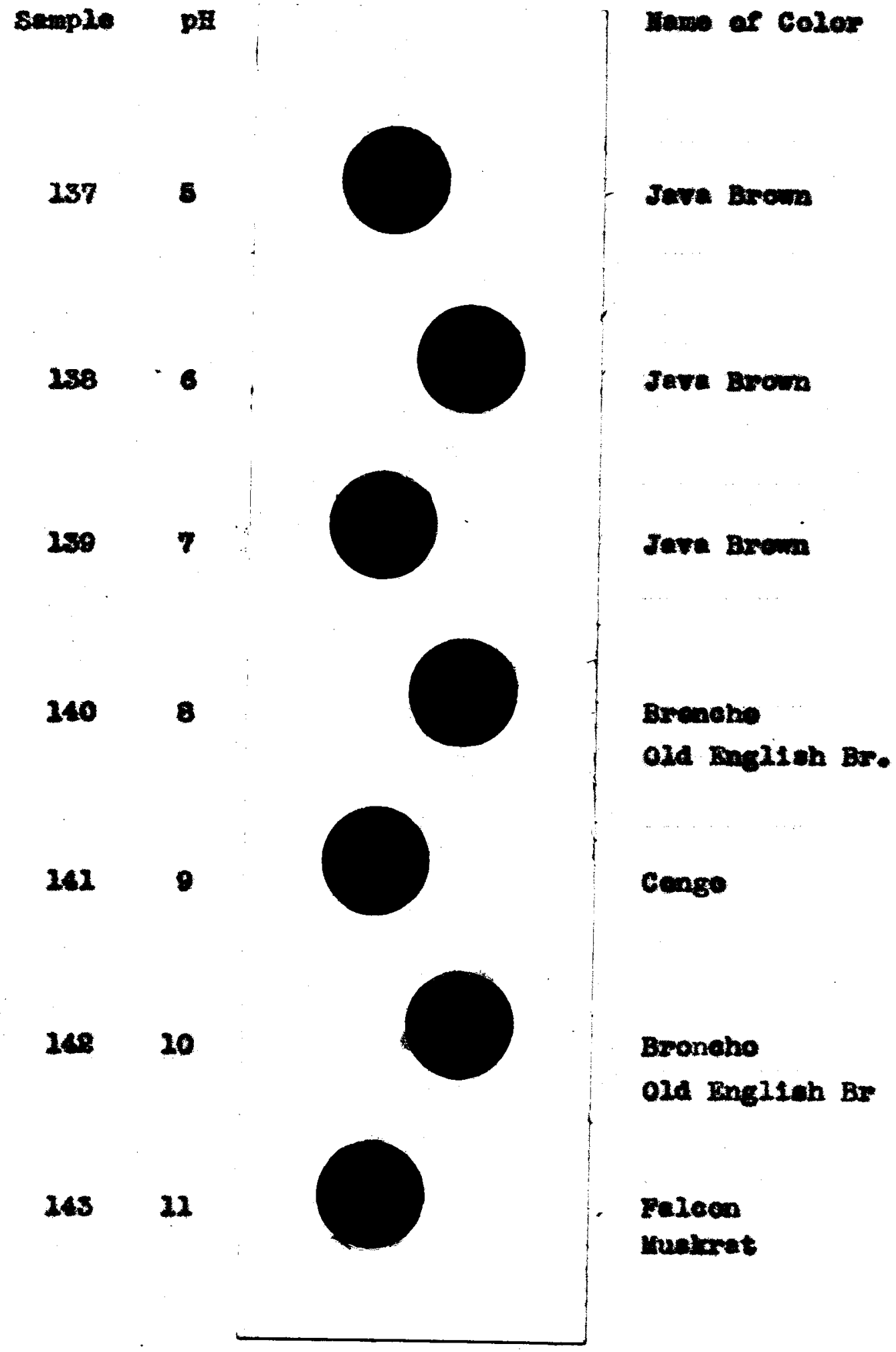


rable xoxin.

Erfeot of variation of Apdrogen Ion concentration of Zine Itrate 8elutions with Mitrie sold and sediu Harentie.

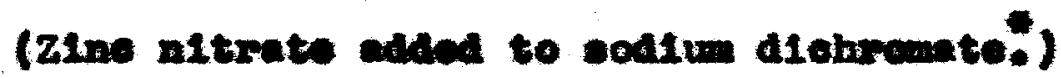

souple

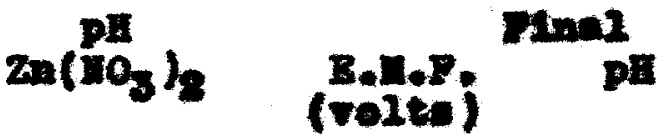

24

$\mathbf{2}$

145

146

$\mathbf{1 4 7}$

249

249

150

161

268

253

164

\section{8}

3

4

5

6

7

-

-

10

11

$-.0050$

$-0.3009$

$-.3225$

$-.2500$

$-6000$

$-.2815$

$-.0080$

- mos
Solub20

2.6

2.6

2.0

8.4

3.8

40

6.6

6.2

7.5

6.2

Romarios.

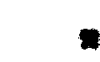

$\bullet$

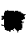

-

$\bullet$

sught ppt.

Eaw ppt.

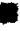

-

- Tpe pI or the sedium Alobromate 8.5 . This cortes is very comperable to the corles produced in Fablo JxVIII, which is the roveree mothod of striking. 


\section{Tabie xov}

Comparieon of Pulp Colore Propared srou zino nitrato and sodlum biohranate.

\begin{tabular}{|c|c|c|}
\hline Semplo & Index & Nowe of Calor \\
\hline 20 & $P 28-8$ & Buolithern Br. Bumec \\
\hline 250 & $P 15-8 \pi$ & Ohtpanenik \\
\hline 252 & P23- 8L & Backthors Br, Sumpe \\
\hline 158 & 223- ox & Ohtyainls \\
\hline 253 & R13-a & \\
\hline 164 & P23- or & Cheswant \\
\hline
\end{tabular}
Table $\mathbf{x x I V}$.

All the preespitates, excopt Ho. 150, had a Light yellow color hotrogeneoukly mined in with the brom prealpitate, whioh wode up the bril of the color. The cextes of colors, axeept for the yollow procipitete, wes constant with no definite broak in color and no partioular offohodes. 
a

\title{
Table x000x.
}

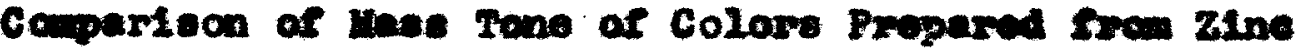

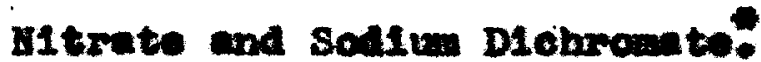

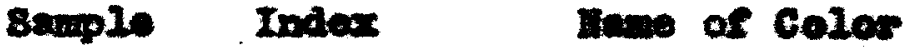 \\ $190 \quad$ P25-10R \\ 151 P25- QL \\ $269 \quad$ P25 $9 \mathrm{x}$ \\ 253 P24- TL O2A Bromso \\ 254 P26- OE \\ - Colore preparod under ecadltian of
}

Table xoxr.

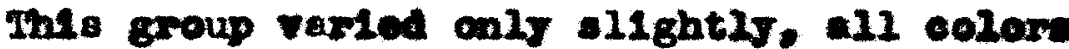
wore a mediun brown or a grean brown. 


\section{Color chart 11.}

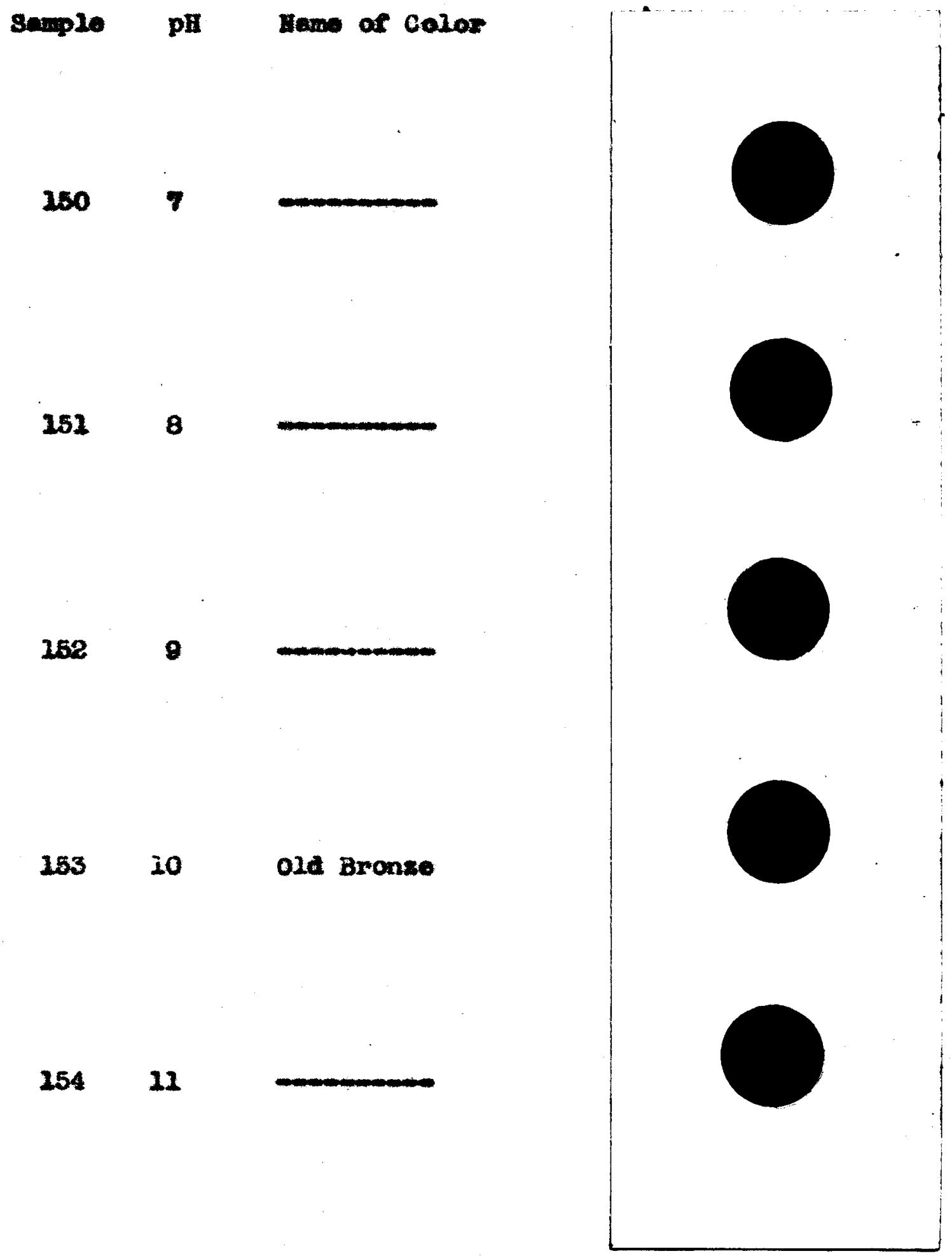




\section{Coneral Comparison of Colare Propared}

trom Z1no Iltrate.

Twe procipitates from sine nitrate and eodiun diohromete were sromed only whon the basie aelt of sine kydroxide was preoent before atriking. All the colore wore brom excopt wore the prealpite te was intermingled with ight yellew oolor. The wothod of striking had littlo erfeot on the var1ation of the pulp coler. atinos the two corted of eolow propered by wovere mothode of otmking (Tnbles XXVIII and XXXI) wase practLealiy the same. Tw other series of odlore (mable XXCI) was wore constant and the colerv apre distinet brown than the other colore prodused from sine nitrate.

The waen sones were all brome or croenbromn. The mothod of atriking hed 1ittie efroet on the mase tones, as it bad on the pulp solors. Nost of the colers more a dirty color and not a geod color es those produped from other motals. 
$\infty$

CAnuru cERomss 


\section{Ceduliu Chromate.}

Iormal eachan chrounte bas been propared by 8. H. C. Brigge (28) by heating a mixture of eadsiv axide and ohroming trioxide in a sealod tube fos three houre at 200 degreos Centegrade. It was aleo prepared by J. Sehules (8) Irom cadmin diahromate and cadnitu hydroxide undor preotienly the sam comaltions. The normal salt is e jellow aryetalilno ponder. Banle salte have been formed that have orango-yellow color varying alightly with difforent compositione. The basto ohremate, locording to $F$. Rose (20), has been used as yellew pltment but Ite cost 2 imite it to fine art work. 


\section{rable $\mathbf{0 x v I x}$}

refeet of veriation of Hydrogen Ion conoentration of Cadnive Ittrate Bolutions with Mitrie Aold and selliw Hyaraide. (sodium dichromato aded to oedmium nitrate)

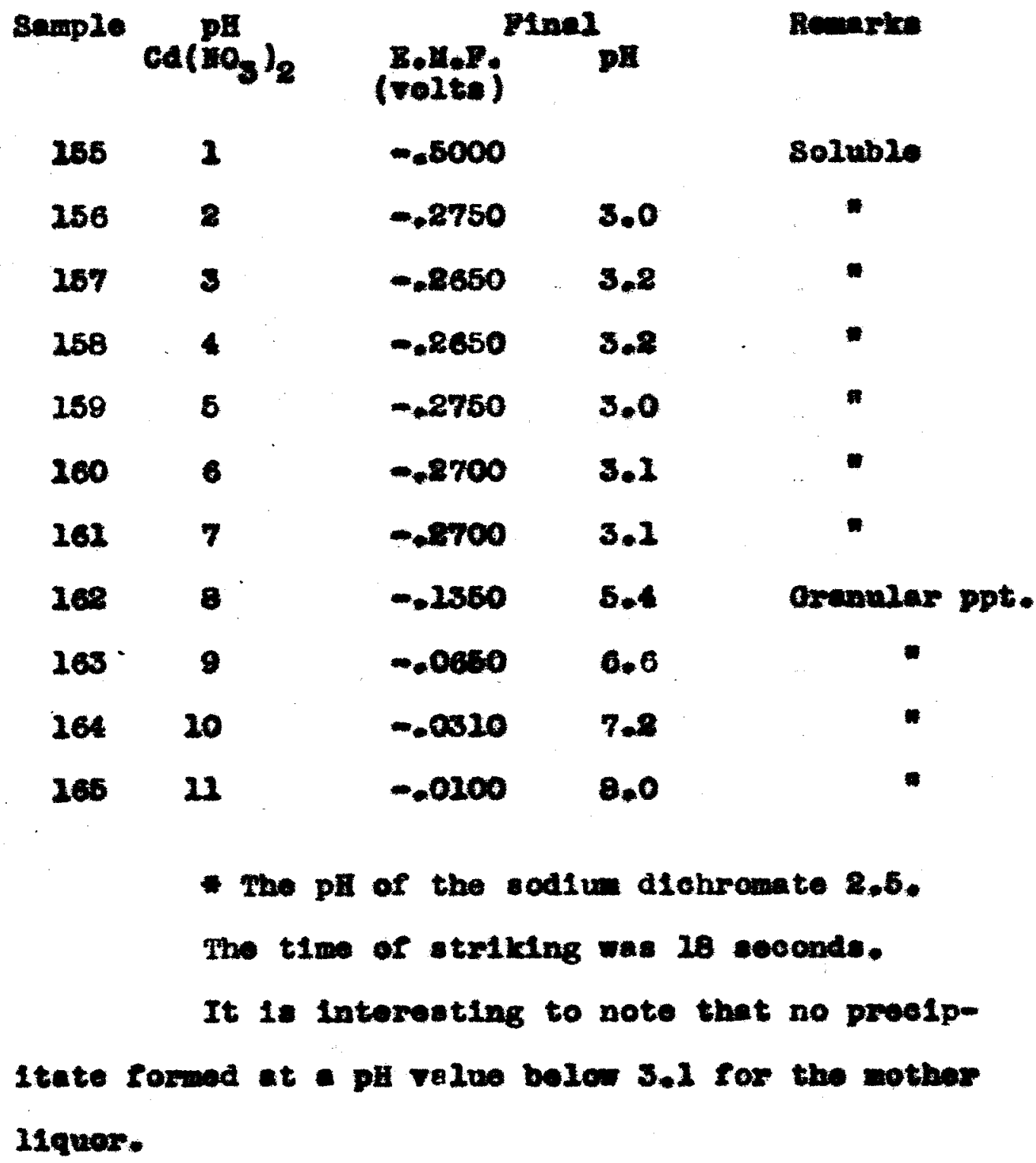


rable xorvIII.

Cemparison of Pulp Celore Preparod from Cednim Mitrate and sollu Dlehromate*

Sample Index ramo of colos

$168 P-2 J$

$265 P 9-2 x$

$264 \quad P 9-2 x$

$166 \mathrm{P}-\mathrm{IL}$

- Colore propared undor senditiens or

Table XXXVII.

mis cories of colore veried little, ell

were yellowe characteriatio of insoluble cadulum

chromete. Ho broak or affebudes wore notied.

Table $\operatorname{xax}$

Ceaparteen of thas Tone of Colore Propared from Gadaim Iltwate and sodim Diehremato.

samp20 Index low of colar.

202 P18- II Sulphine $Y$

165 P10- 81

264 P2R-3r. Clouty Ambor

265 P12- 52 Pyot te $Y$

* colore proparea in Table XxarI.

All the color were yellows with allght

variations srom a exen to modium rollew. 
Color Chart 12.

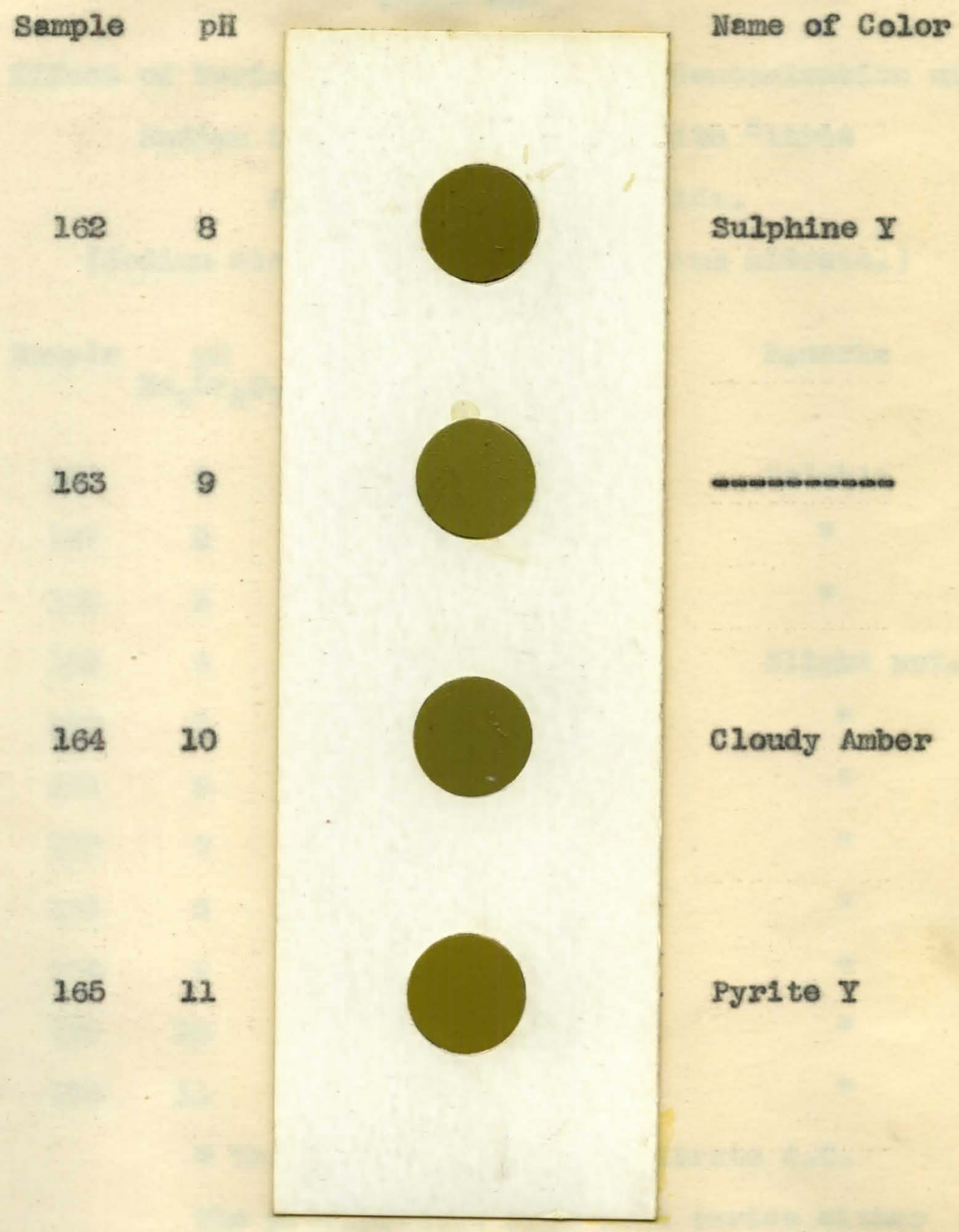




\section{rable $x$}

Exeot of Variation of Herogen Ion ceneentzation af

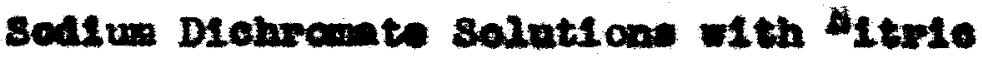
Moid and Sedim Driromide.

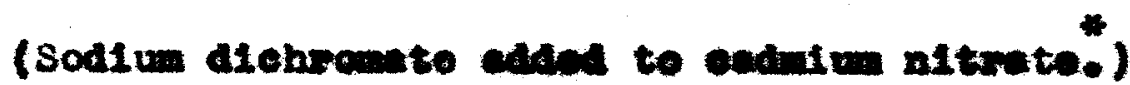

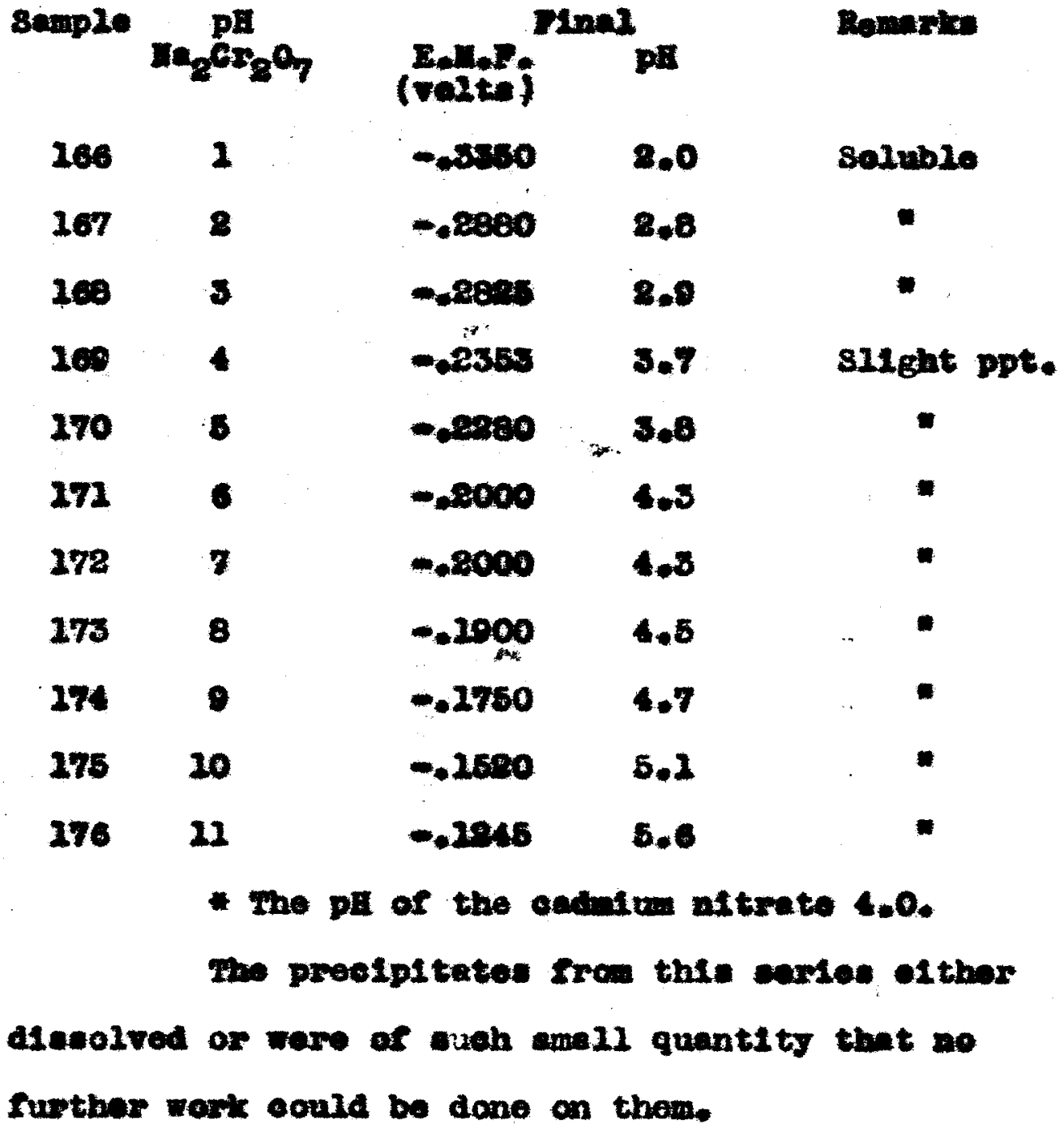




\section{2nolo xit.}

Effeot of Variation of hydrogen Ion concentration of Cadmium ultrate Solutions with Mitrie letd and Sodium bydroxide. (Cednim nitrate added to tho adivm denriante")

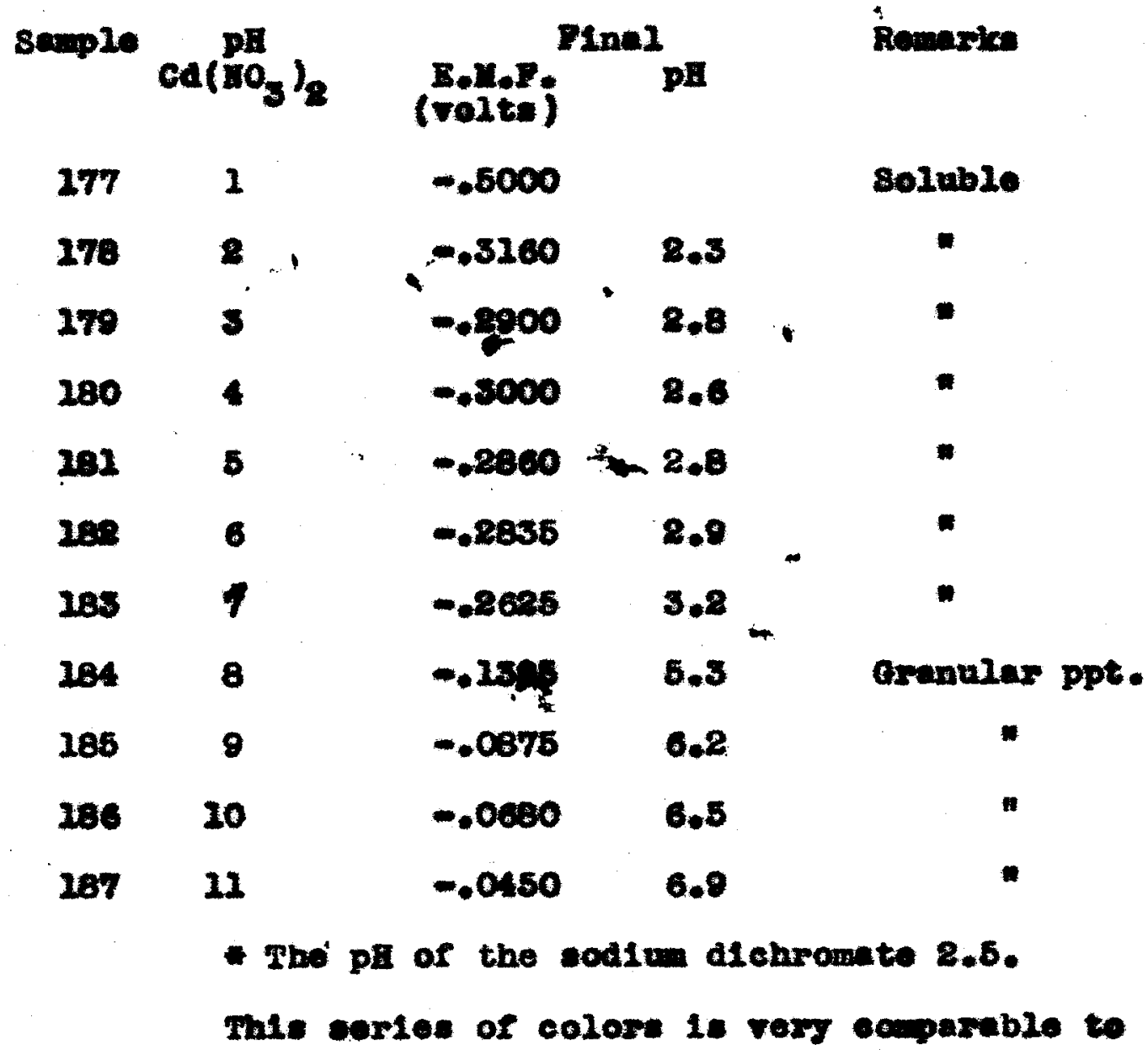
rable JoxvI, in the quantity of preelpitate, the pII at which preolpitetes formod and the color. 


\section{Table xhI.}

Comparizon of Pulp Colore Propared Irom Cadilum Iltrate and soliu Diohrometo:

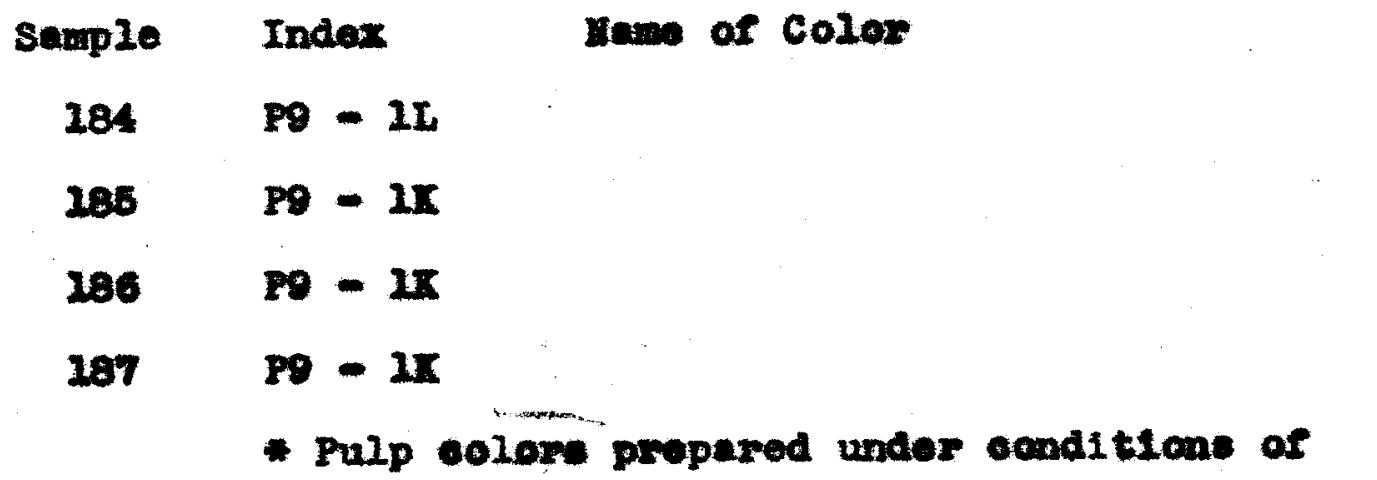

Tabie XII.

12 the calow were the characterietie yollow af cadnive ehremate, with Ho. 184 elighth daricer then othore.

\section{Table xIII.}

Comparison of uas rane of Colore Prepared from Cedulu Mtrate and Sodim Diobromete.

$$
\begin{aligned}
& \text { 8ouple Index Hewe of Color } \\
& 184 \quad p 9-21 \\
& 185 P 9-2 x \\
& 186 \text { P9 }-2 x \\
& 187 \text { PQ }-2 x \\
& \text { * Color prepered from Tablo XIT. } \\
& \text { All the celor were jellews. }
\end{aligned}
$$


Color Chart 23.

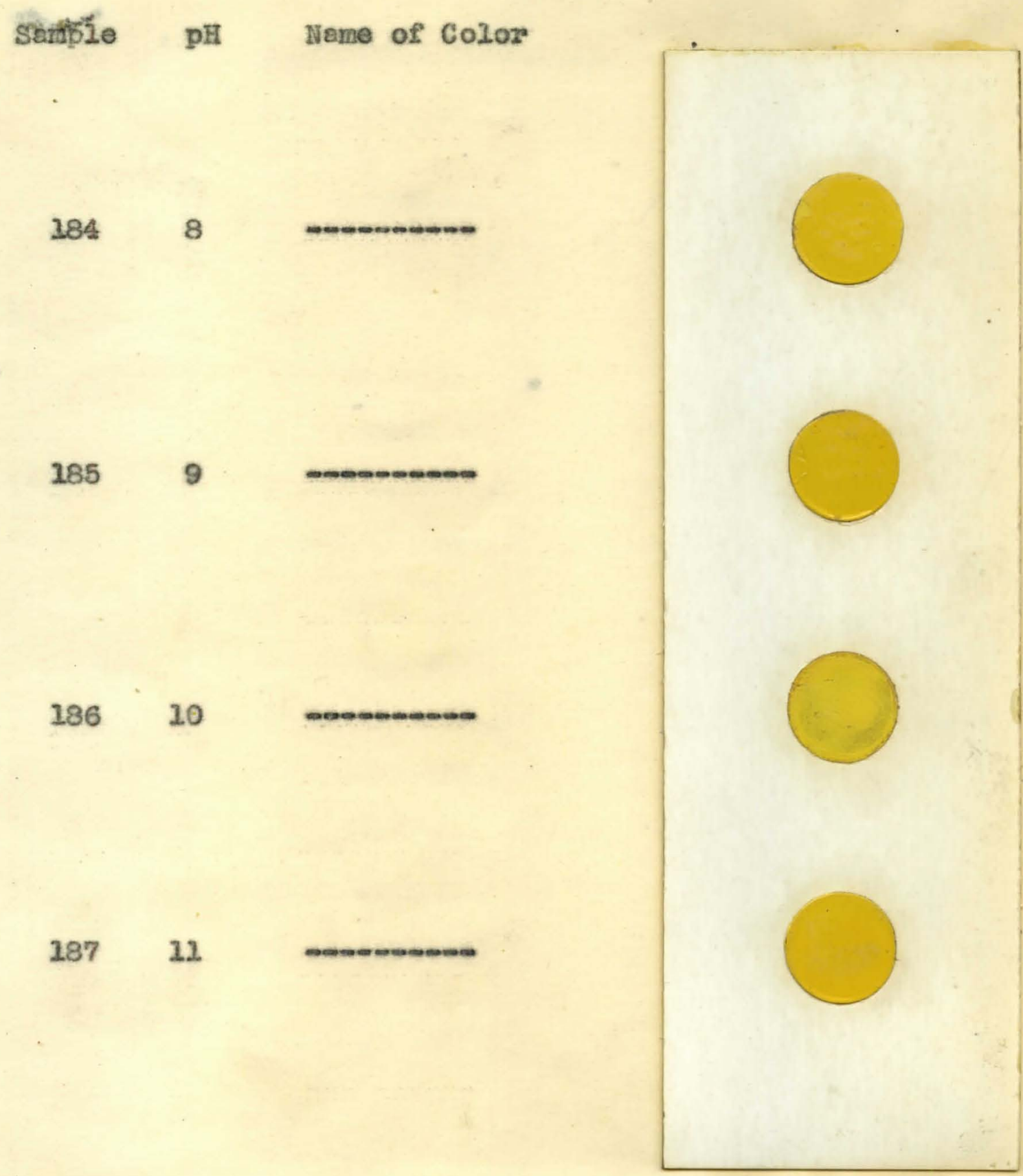


Goneral comparisca of Colore Propared from cabini Mitrato.

It 111 be notieed that only fow oolors in osoh Gromp wore compared, and that each color was forwod from aclution with e finel pfl groator than :5.0. In Table XI the slight procipitate wee not the color of cedmin ohresate until the einal pll of the volution was groeter than 5.0. The proclpitated that formed in solutione of lemer finul pH ralues alseolved

- whon washed, and a very amell quantity of preelpitate formed in the solutions of pH value of 5.0 or grester. The quantity of prosipitate in this group did not verrant furthor considoration. The pulp colore and the mass tones were almost lanticel in ench onee. They were all yellow varying only alightly olther to aresm or a modium jel10m. 
、

yomounc choung 


\section{We: die Chrometo.

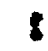

Morwal morourte chrowate was propared by

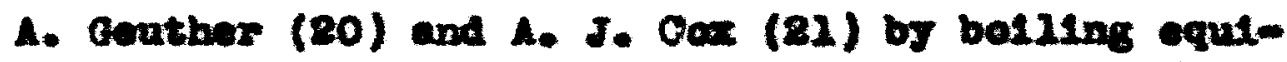
wolar parte of ehroule oride and yellew mexourle oxide with water. The nownel ealt hydrolisen in

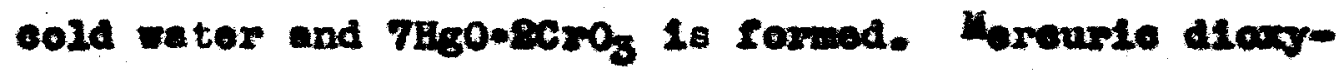
ohrowe te has boen propared by ceveral experimentere.

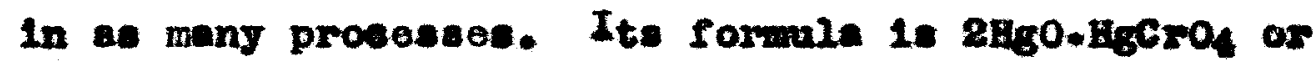
$3 H_{g O}-\mathrm{CrO}_{8}$ - Many other basio slate have been propard. and wany complex ealte form with woroury and obromium. The bas10 salte have been secoonding to $\mathrm{F}$. Rose (10). uped en plgments, undar the common names of purplo rod or chrome red. F. Flehter (22) and 6 . Oesterneld (2e) elaim the colox of the proolpitate depends upon the temperature. a jellem or golden brown prealpitat sooulte from a cold solution with an arsene of chrom mate; while, anker prealpitates rooulte from a hot colution. Basie moreurie ehromate $\left(\mathrm{Hg}_{8} \mathrm{Cr}_{3} \mathrm{O}_{23}\right)$ sosult. from hydrolyeis of moraurle ohromate in cold solutiene. A brick nod worourle chromete $\left(\mathrm{Hg}_{6} \mathrm{Cr}_{8} \mathrm{O}_{9}\right)$ forwod slowly in cold but rapldiy in hot solutgion. when an excees of wereurle nitrate was present. 
mable 2.r. $\pi$

Efreot of Variation of Ardrogen Ion Conoentration of Solium Diohroante Solution with IItric

Lold and sediva Haroxide.

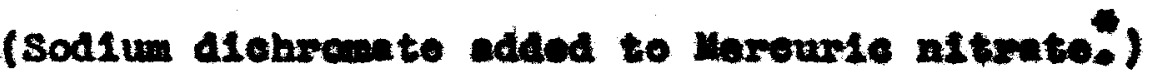

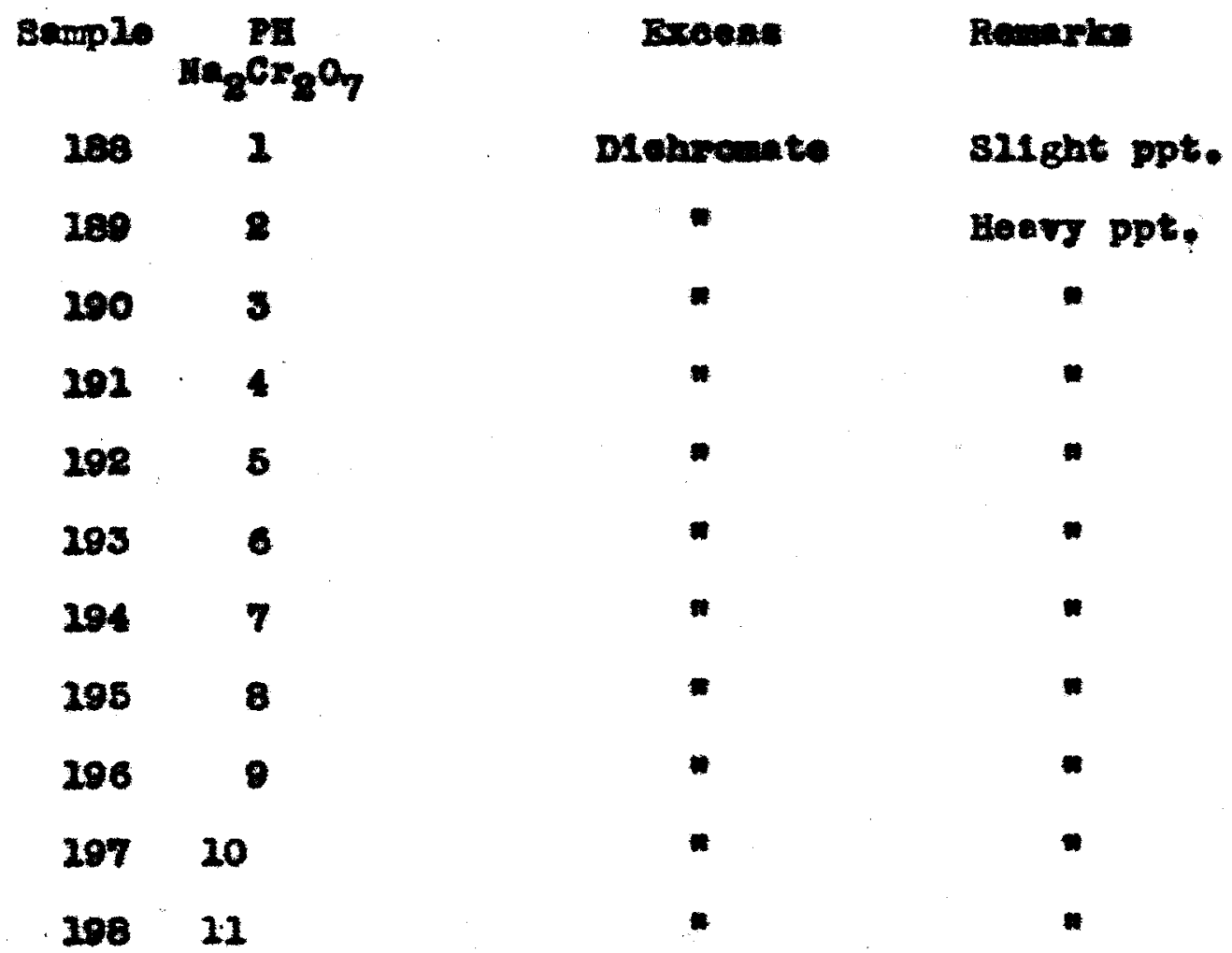

- It was found inposelblo to obtain the pH of mercuric nitrate solutions with the quinhydrone - loetrede, so the pB of the sodium dichromete was reried and added to the morenrie nitrate solution, whoh wat a near noutral as could be ebtalnod without hydrolrais. 
nobse xro

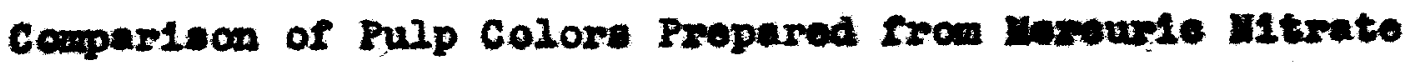
and sodium Diohronate.

\begin{tabular}{|c|c|c|}
\hline Sample & Index: & Now of Coler. \\
\hline 280 & $P 4-212$ & Redroather. Buidhe \\
\hline 200 & $P 4-28 x$ & Brast2 $R$ \\
\hline 201 & $P 3-221$ & Tomento $\mathrm{R}$. Mhive \\
\hline 202 & P4 -18x & Brast12 R \\
\hline 203 & $P 4-20 x$ & Bpast1 $\mathrm{R}$ \\
\hline 104 & Ps $-12 \pi$ & \\
\hline 106 & Ps $-12 J$ & Better smeet \\
\hline 196 & $15-28 d$ & Bltter sweot \\
\hline 187 & $28-20 x$ & Bittex smet \\
\hline 108 & P3 -18X & \\
\hline
\end{tabular}

rable XLIV.

the colose of this sortes varted frem a aop sed to a deep redulab orange, with no extahodes. Io. 201 (pH 4) wa ellghtly 11ghter chowing a reddiah orange oomparable to Noe. $205-298$ (pH $8-21)$. There wae the yellowion brom proolpltate on top or the sottled color almllar to that already menticned. 
Table xwe.

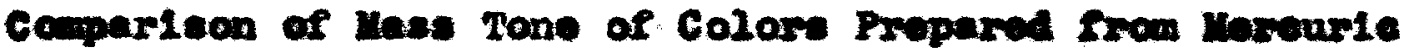
ILtrate and sedivm DLahromate:

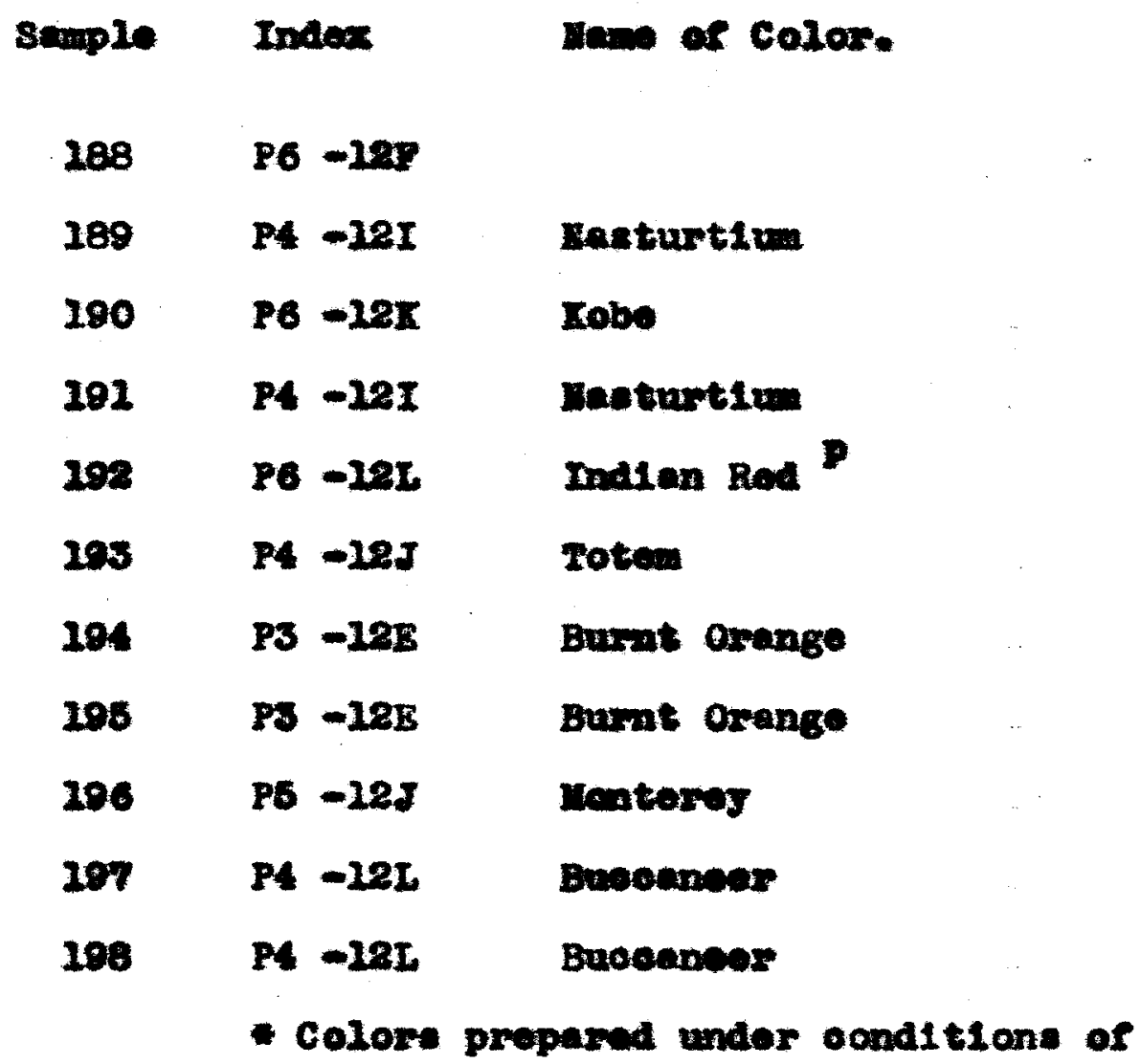

rable XIIV.

The nertes of celors varted from brom to a rod orange. Ho, 188 wa brom, Nos, 189 - 291 wero a medium orange, Hoe. 298 - 193 were zod brome, Hoa. 104 - 198 were good orange. and Hoe. 296 - 198 wore a rod brom. 
color chart 24.

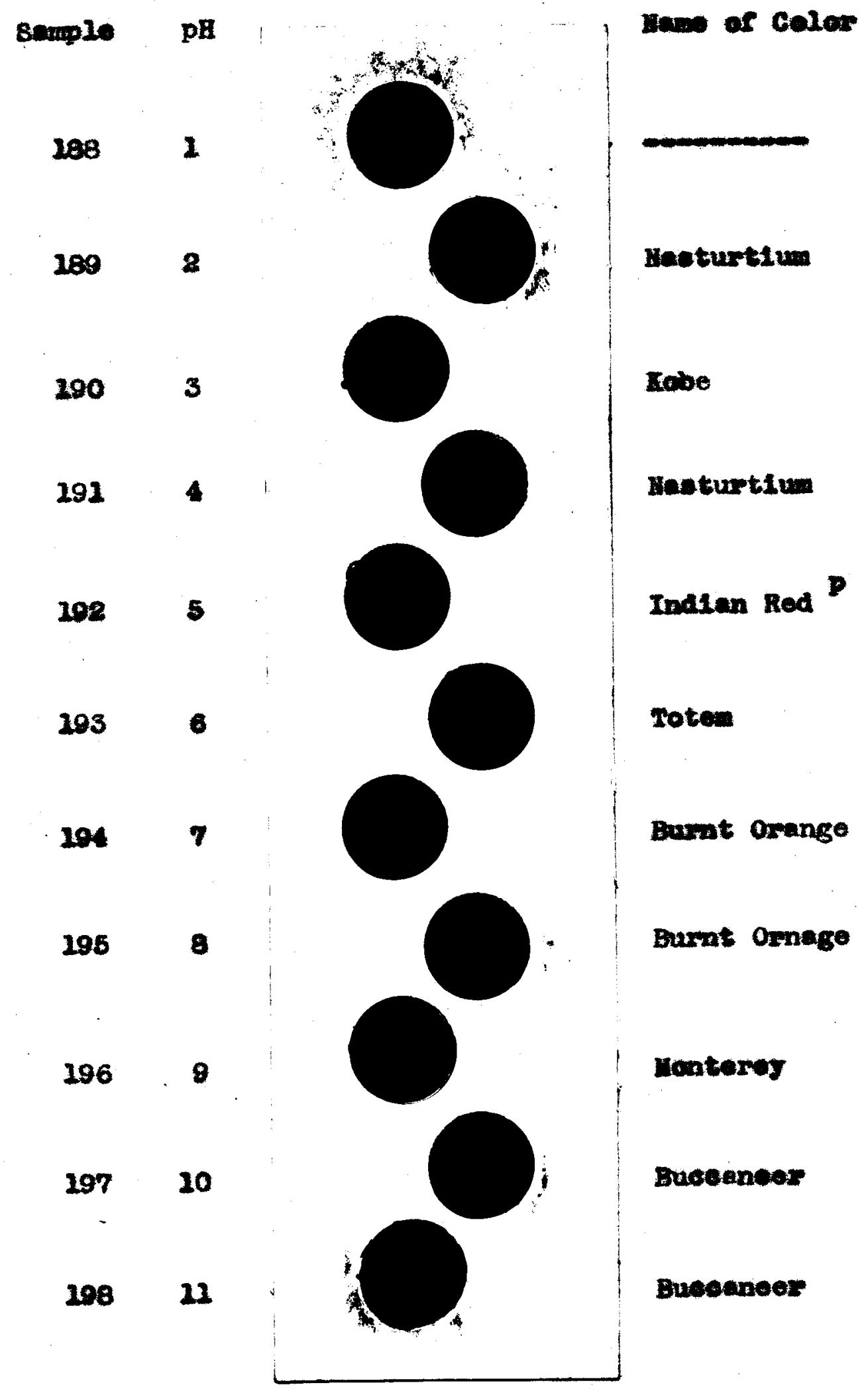




\section{2abio xrx.}

Effeot of variation of Hodrogen Ion Cosoentintion of

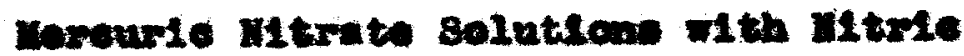

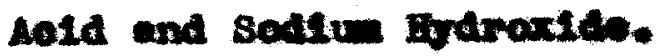
(woreurie IItrate" aded to sodiun diehromito.)

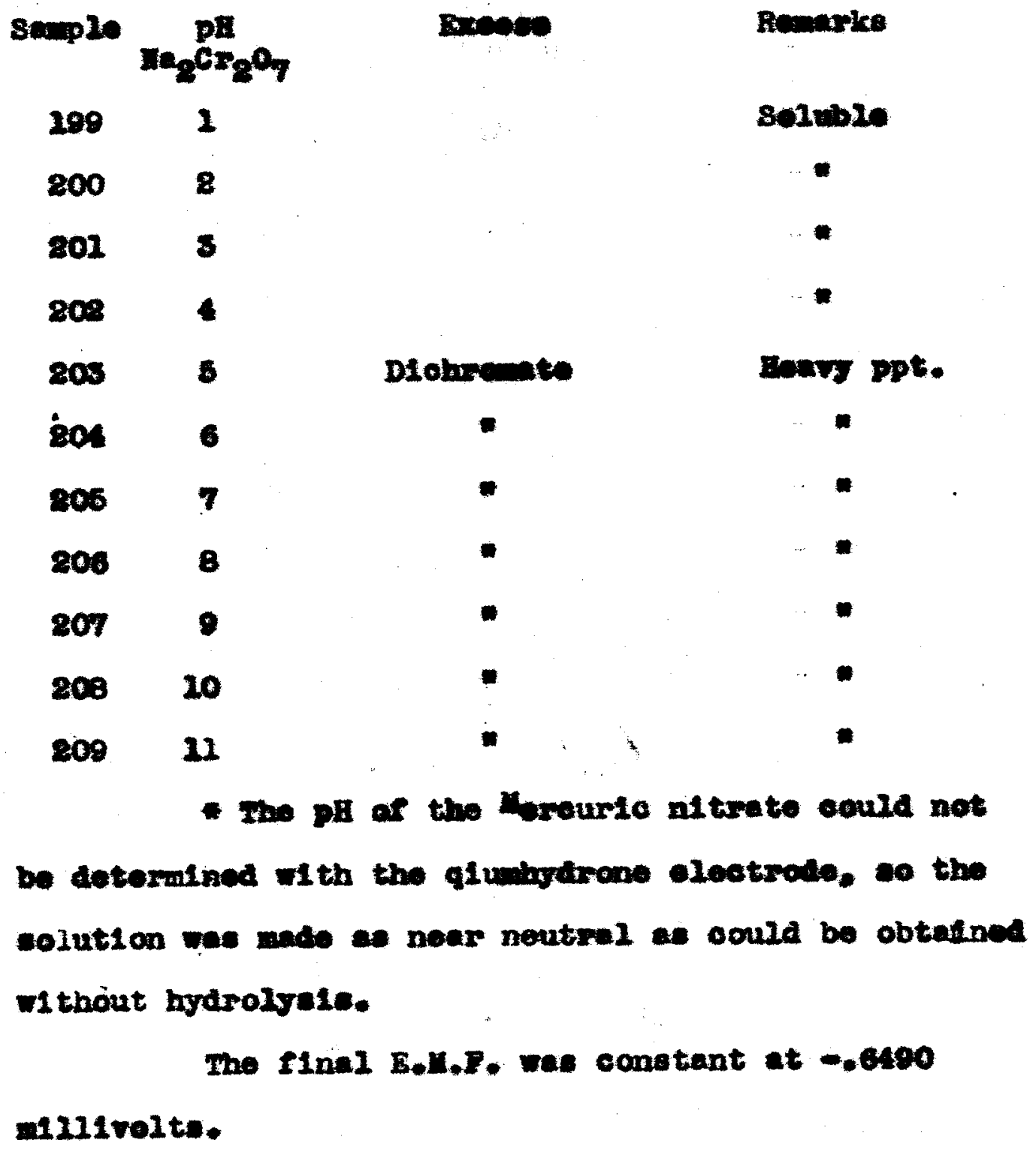




\section{2able xHrII.}

Comparisen of Pulp Celore Propared Srom unpourle Iltanto and Sodiv Dehroesto.

\begin{tabular}{|c|c|c|}
\hline Somple & Index & Ino a colas \\
\hline 208 & $p-12 x$ & udalght su \\
\hline 204 & PR - 19 & $\operatorname{man} a x_{10} \mathrm{~B}$ \\
\hline 205 & $P 8-12 t$ & Oxange Vorwallad \\
\hline 206 & $x-190$ & Orange vormi21da \\
\hline 207 & $P 2-120$ & orange Verailion \\
\hline 800 & $P E=120$ & Orange Vexwilion \\
\hline 20 & $12-180$ & orenge Vermilion \\
\hline
\end{tabular}

- Pwip colore proparod under condittone

of Tabie Xuvr.

The series varien littie with no errohedes. Hos. $206-200$ were the sewe, while the othere were endy allght shede IIghter orange. 121 the colar were a good orange. 
rable xux.

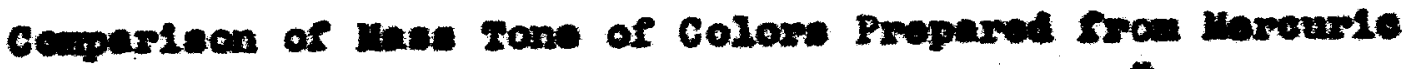
Iitrate and sodivn Diohromete.

Semplo Index

Hawe of Calar.

\begin{tabular}{|c|c|c|}
\hline 805 & PS -120 & T2le $R_{0}$ Charolues \\
\hline 804 & $p 3-19 c$ & \\
\hline 205 & P3 $-28 I$ & 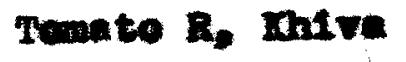 \\
\hline 208 & $P 3-19 \pi$ & \\
\hline 207 & P3 - 121 & \\
\hline 200 & Ps - 221 & \\
\hline & $P 3-28 E$ & \\
\hline
\end{tabular}

- Color prepared under conditions of rable XLVII.

This series veried $11 t$ te all belng orango.

10. 203 - 204 wore a light shade of ormabe. Ho. 204 - more roddith ornnge, and the othere (Hea. $206-200$ ) wore typleal oranges. 
Color Chart 15.

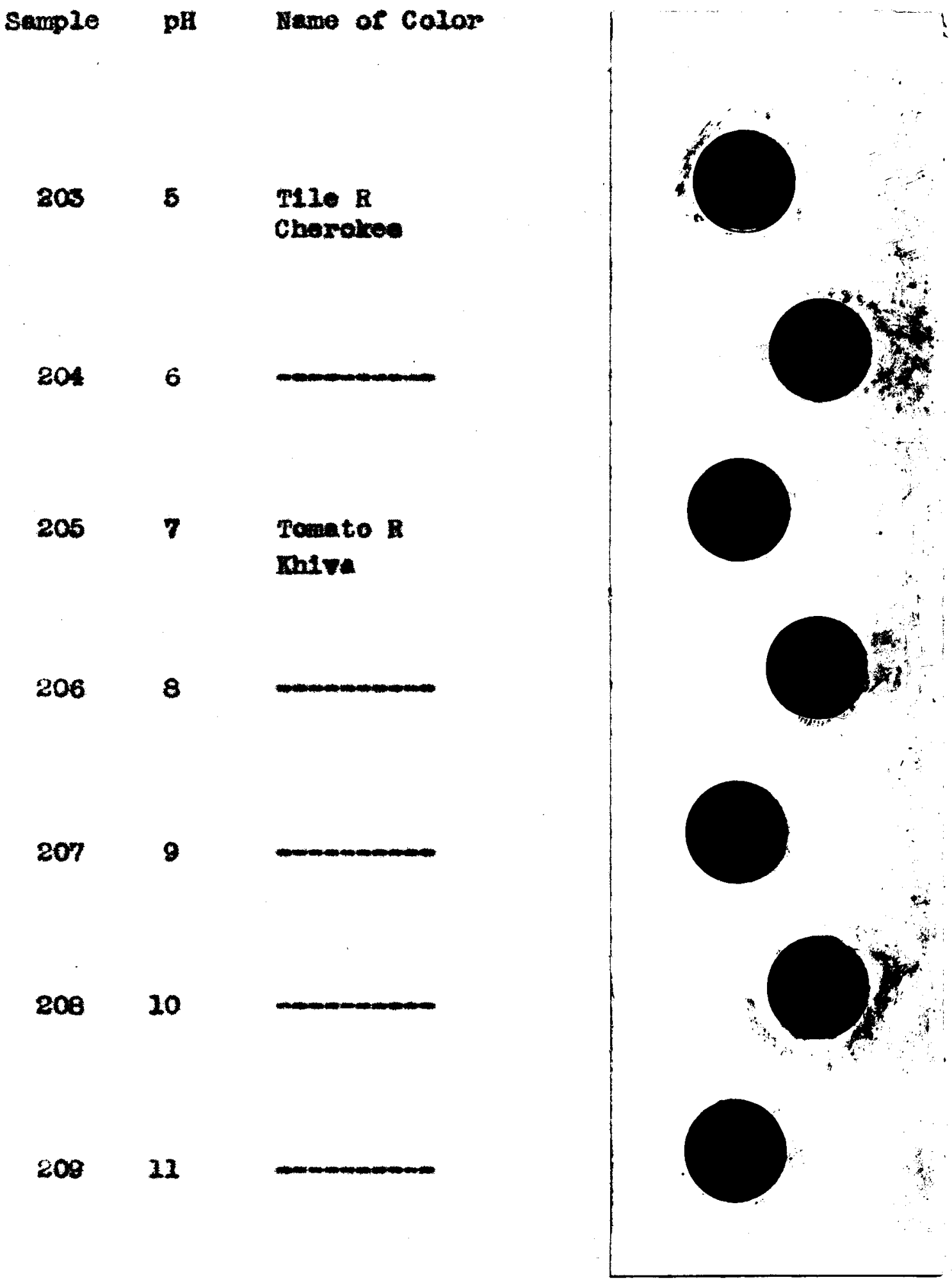




\section{Gonoral Couparison of Color Propared Iron Horcurie nitrete.}

8inoe it was found to be imponsible to obtain the pH of noreury 100 solution with the Quinm

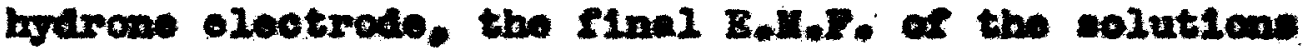
were undoubtedis not true pI velues. The guntity of procipitate in eeoh eeries was almost the samo. The pulp solore of the proctpltates from the two groupe of colowe wore very different, beving onis - ellght resemblenes in 22 boing seme bhade of rea ar orange.

The wases tones of the twe seried of colere wro rery different. The firet group of colors was very variable (free arown to a red), while the weond group was very conotent. Ho colore were the save in the two sorros. 



\section{Aluninu Chromte.}

\section{Nocording to HoLler (23) no entlaratory}

oridenos has been obtainod that wluminum ehremate existe as normal selt, but all evidence proves soveral basio wolte have been leentifled. Sem

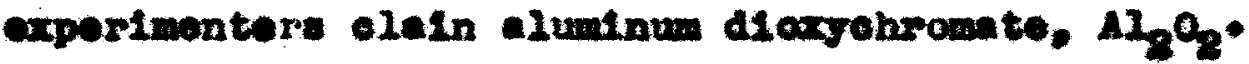

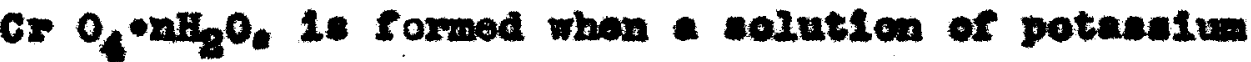
slun and poteselum ohromate were ared. othore elain it is imporeible to obtain ouoh a prosipltate from thoee solut1ons. H. arbger (24) obtained a yellow precipitate from eluminu chloride and potagalum ohromate. Mon the ratio of aluninum ohlowida end potessium ohroate was an mole to three moles the proelpitation was eomplete. S.H.C.Brigge (25) obtained, by experimonts almilar to those alroady discused, lewon jollew, Insoluble product which

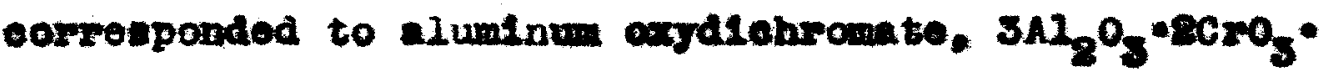
$\theta{ }_{8}{ }^{0 .}$ 


\section{Tabie to}

Effeet of Variation of Hydrogon Ien Conpontration of Aluane mitrate Solution with mitrie sold and sodium Hyaroside. (Sodiu Alobrometo edded to alwainu nitrate)

Sample

$$
2\left(\mathrm{PO}_{3}\right)_{3}
$$$$
3
$$

$\mathbf{2 1 0}$

821

219

2234

2145

215

216

217

828

210

280

$$
8
$$$$
3
$$

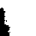

$-.3485$

2.8

3.4

5.2

5.4

6.8

$-.0000$

6.8

$-.0520$

6.8

$+.0630$

8.6
Remarke

solublo

a

-

811ght ppt. Hoav ppt.

a

N.

$\theta$

a.

*

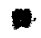

- The pll or the odilun dichromate 8.5

At $\mathrm{pH}$ of 4 (Wb. 213) $\mathrm{MIOH}_{3}$ we prespltated. and at pH of 11 (Ile. 220) sodium aluminate was formad. MII the ohronate eolor wes wanhd frem the prodpltate loaving onls alwainu byiraxide. 
IXNIIT GROMAS

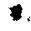




\section{Mtaniun Chromate.}

H. Blondel (26) found that a conocntrated equous solution of chromic acld diseolved titanie cold in mounts dopending on the coneentration and temperature of the colution and the previous hiatery of the titanic eold. He obtained severni basie selta of titenium chromate from the above solutions. 800 of the ealte he propared are lieted bolow. Mtanlum

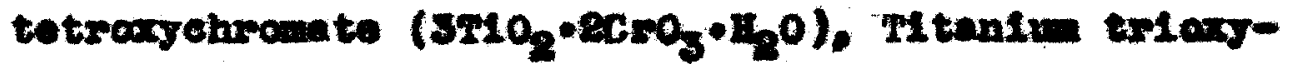

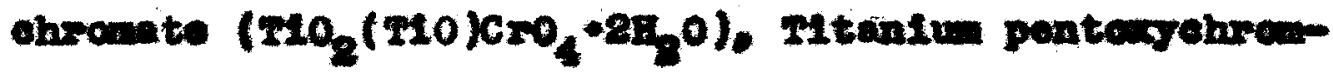
ate $\left(2 \mathrm{MO} \mathrm{O}_{2}(\mathrm{T1O}) \mathrm{CrO}_{4} \cdot 3 \mathrm{H}_{\mathrm{g}} \mathrm{O}\right)$. These compounde bave not yot been voriried.

In this inventigation titanim triehloride and sodiu dichromate was neod. It was found imposable to obtain the pll of the titanime solution with the quinhrarone eledtrode so samples werv tried from aeld and basic solution to dotermine what effect suoh brarogen ion coneontrations would heve on the solution whon wixa.

From tho acld solutions no preolpitate formed, but from the baslo elutione where hoavy preelpltate of the besic titanlum alt had been formed - groeniob grey proelpitate formod which whon thoreughly washed loft only the bavie titaninm axit. 


\section{Staneou Chromate.}

J. J. Berrollue (20) found that whon stomeus

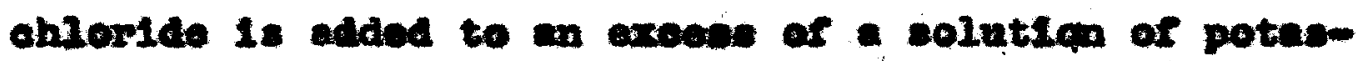
Alu chromato, and the liguid agitated, railion, ourdy rlooks of stannow chromate are preolpitatich Ho

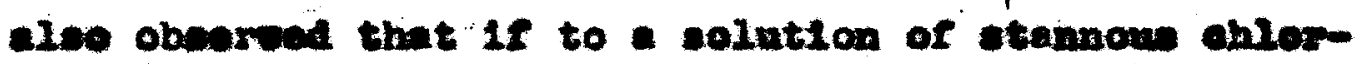
Ide a difte solution of potemelum chromate is aded

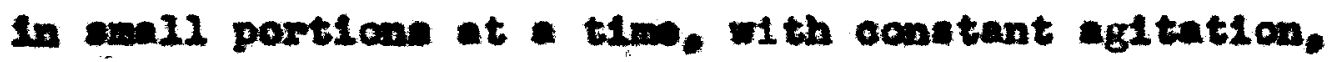
- greenioh proelpitate of ohromie atannate in formed. If the colntion of the tin pelt contalne froe asid. no proolpitete is formed and the selution is groon.

In the imrestigation stannow ohloride was ned. It wa found to be Impoesible to obteln the pI of atannous ohleride solutions with the quinhodreno eleatrode. Sexplos were tried with an acld solution of atannous chlorids which contaned no hodrolised salt. In owh case the solutien whon dichroute was added formed no presipitate. Whon wore beste volutions were uned the basio malt was formed, and colored preolpitate wa obtalned whioh howerer loot all its color whon thoroughy waobed, and the white hydrolized stennowe proelpitete remined. 
When the eclium alchromate wa aded to the more sold solutions the solutione turned green. shoming the formation of ohroutm etennate. Whon the colvition contained only a mall abut of prew elpitated stannow alt before striling the grejen colution formed, but whore lerge mounts of the precipitate was provent no green formed. All the colution showing the green ohromium stannate form mation were very acid to 14 tans. 
Anstro ongerats 


\section{Areonle Chromate.}

A rovien of the literature rovealed no imformation on the compoumel of arwente and obrontur. efthor as ohremetes or ohreadtes.

\section{rable is.}

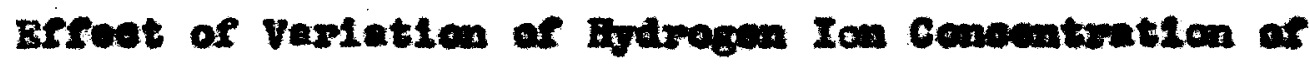

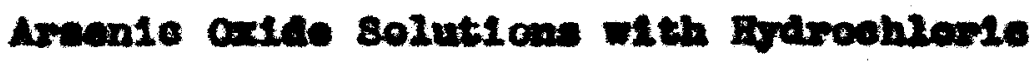

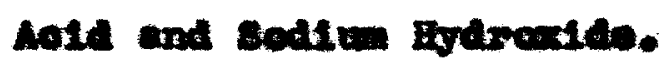

(Sedium diohramate" aded to axwente culde.)

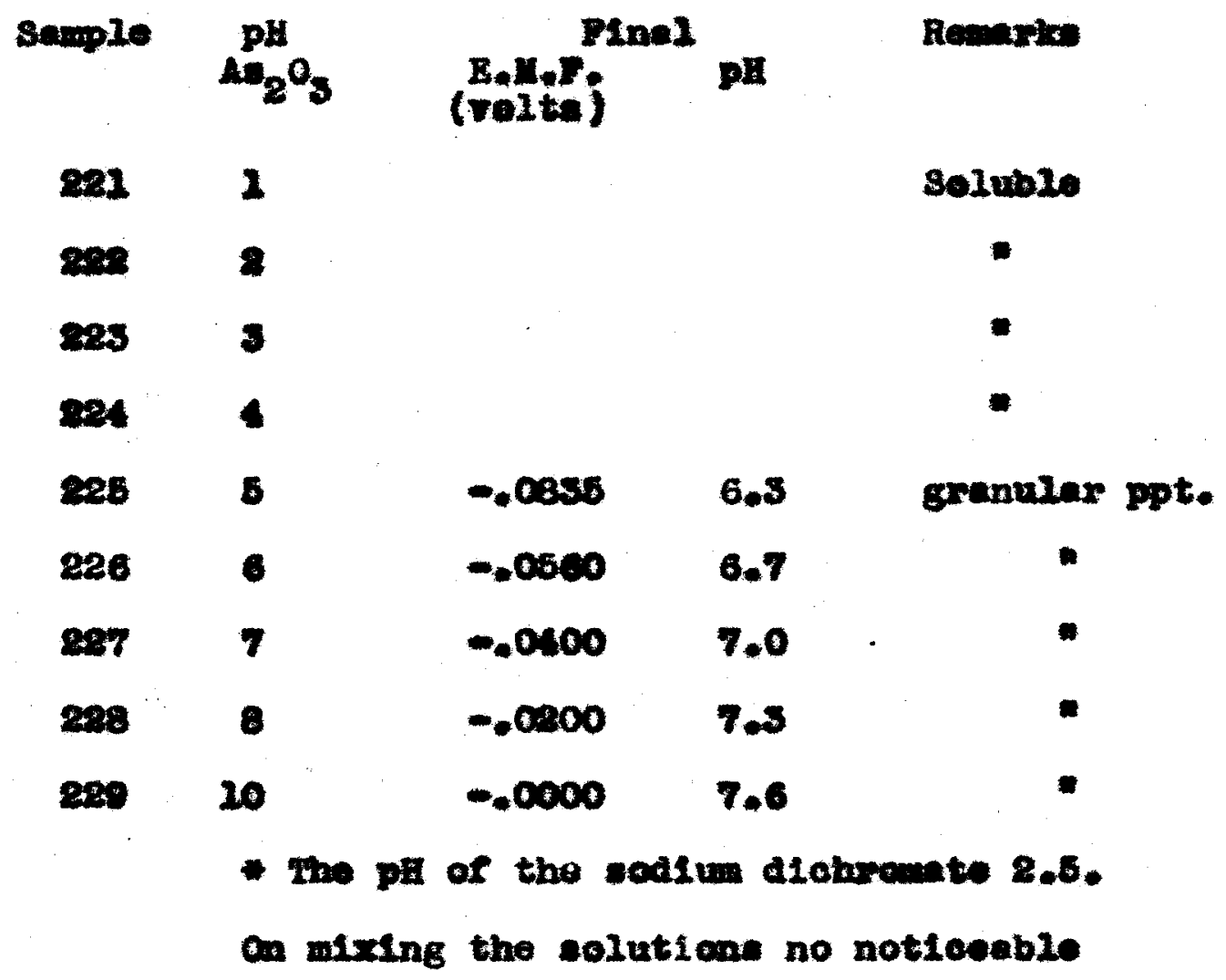


reaction took pleoe but upon egitation for approsimately twe or three minutes a greenioh precipitate formed. It soquired a large anount of callum hourem 1de to obtaln the pll velwe Iren whioh the prodipltate rowned.

-

$$
\text { moble III. }
$$

Comparison of Pulp Colore Propered rrom Areente oride and sodive DLebromate.s

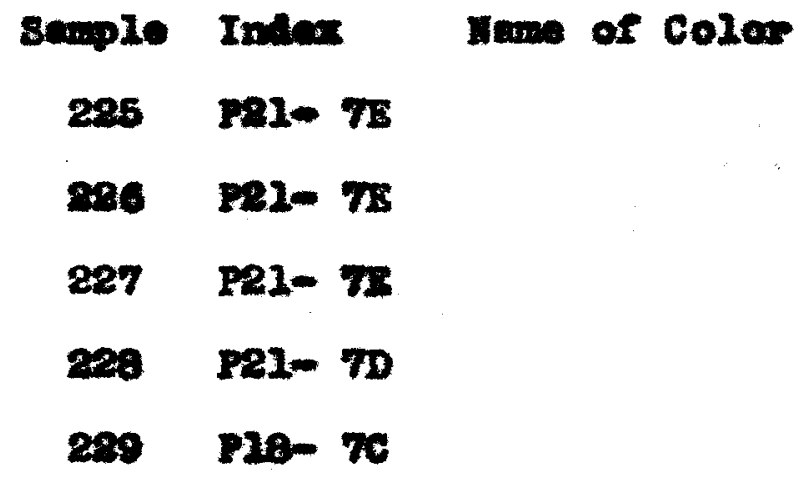

- Pulp colore propaned undor conditions ar rable LI.

Al the celoke were proetioally the sam ahede of groen. Ho. 225 was wore Rloceulent than the othore and had aoverel shades of celor boteregeneoweig mixed in 1t. The higher the pll the more homogenoous the celer. 
Table LIII.

Cemparison of lase Trene of Colors Prepared frem Axpento acide and socliu Diohromate.

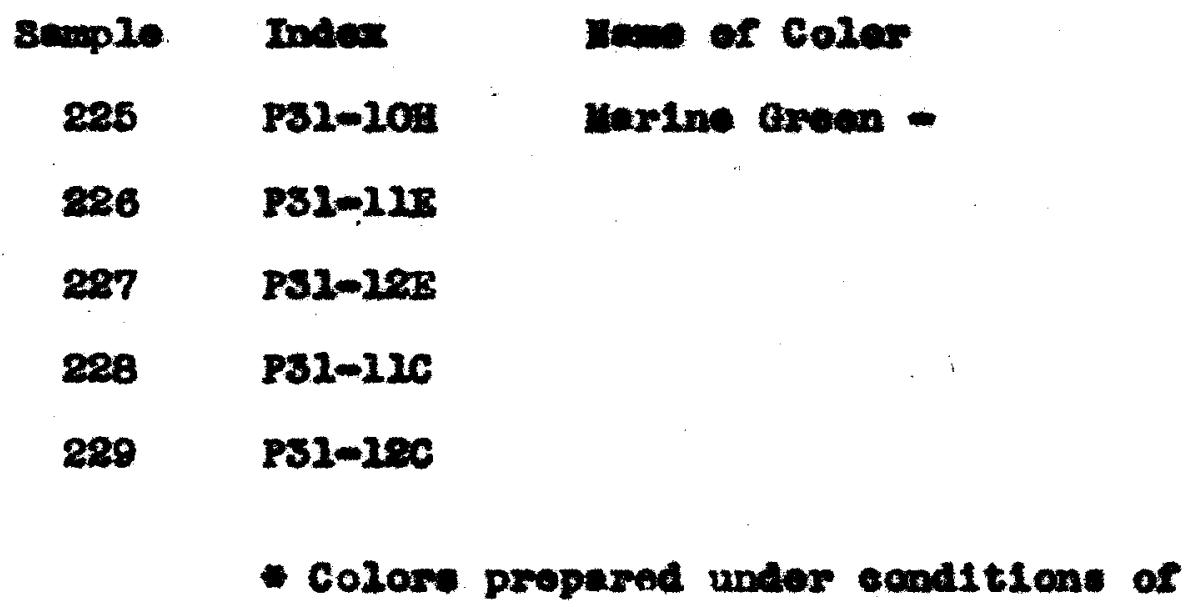
Table IX.

This group of colere wore 021 prectionlly the sowe. Hoo. 226 - 200 wore modium groens whlle Hoe. 225 and 229 were elightly darkex. 
Color chart 16.

Semple $\mathrm{pH}$ Name of Color

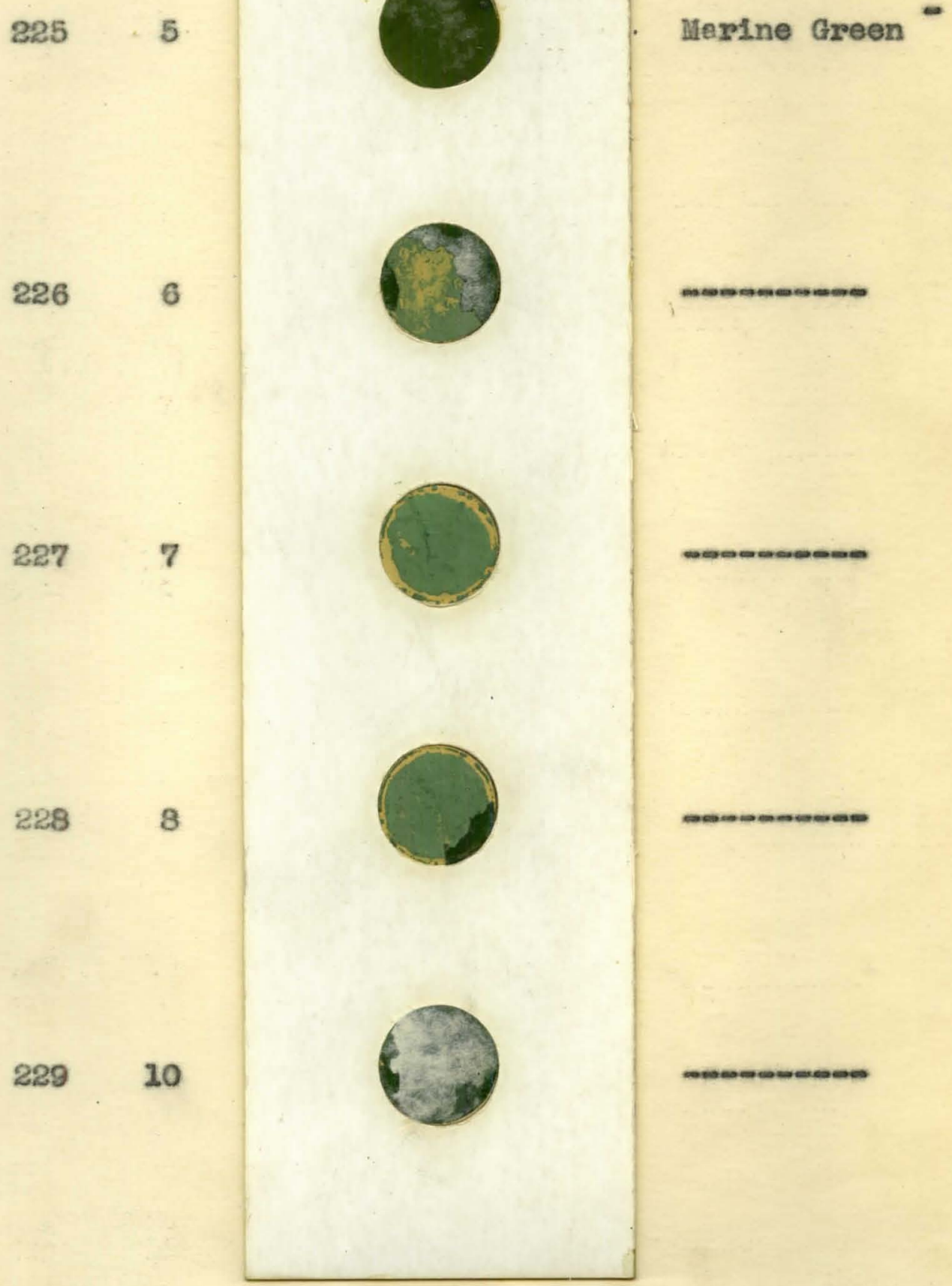




\section{Antimon Chremte.}

Do evidenee has been produced to shom that entimony forme noxwal chromate. 8.H.G.Brigge (25) In experimante elnilar to those in which ho Sormed many nownel obromates produced, by varying

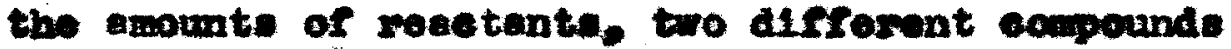
of derinite composition. Dew we entimony exyehrantito

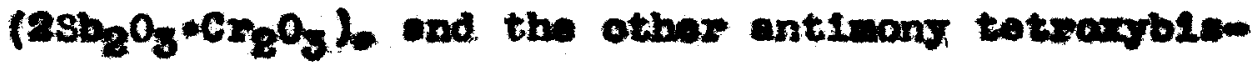

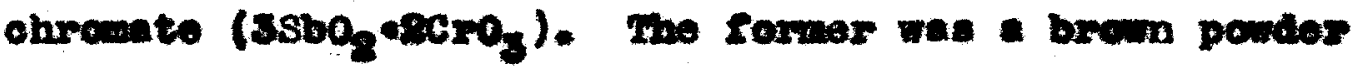

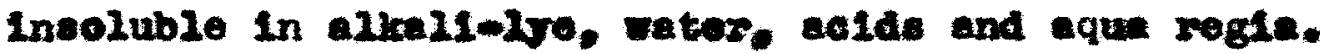
The 2atter was orangeryellem, inacluble in water, and

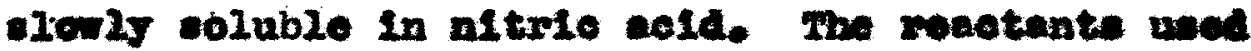
wore antimony axide, obremie axide, and water. Tho Intter two reactents ware varled in the axporimonts. In this investigation antimon trichlaride solution wero uned. severel semples at difforent py relues were otruek with sodilu diehrome solution. In eah oase any proelpitate thet formed renbed completely free of enrowate after one or two wablngs. Ho furthor study was made of this group. 
BISWUTA GIROMATE 


\section{Btemath Chromate.}

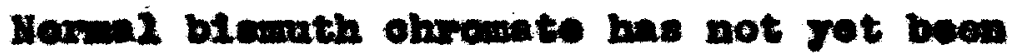
propared but severel acmplex and bale selte have boon. Hout of these basie and oomplex alte wore prepered from bot coneentrated solutione of biswath Atre te and potenelum chremate or diohromate. J. Ifwe (30) prepared a abstance. probebly biamuthrl pexedichromate, by pouring a solution of biamuth nitrate. costulning as 21ttio Iroe nitrio aeld as poosible. Into an excese of a solution of potaselum shremate. The produet was a Iemon yellow. Heroexyetaline pomder, whioh fosmed a red besle onlt when bolled with seda-1ye. H. H. P. Mre (s2) obtalned blemuthol obramete ((BIO) $\left.)_{2} \mathrm{CrO}_{4}\right)_{0}$ a rad pomion. Srom a mixture of solutions of blawath nitirate an potanelve ohromate or dichromate and a fer drops of nitrie cold, when the solutione wero bellod for

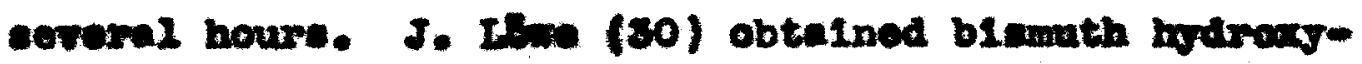
ohromete srom nearly noutoral solutions of the nitrate and in excese of potaselum dishremate by bolling the solution. for some time. 
Tabze IrV.

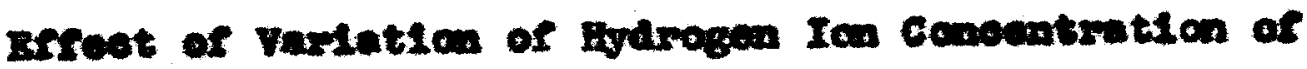

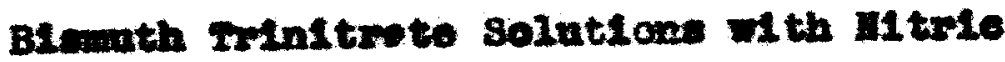
seld and sodin tydroxide. (Sodiv alohremate" aded to blemith trinitrate)

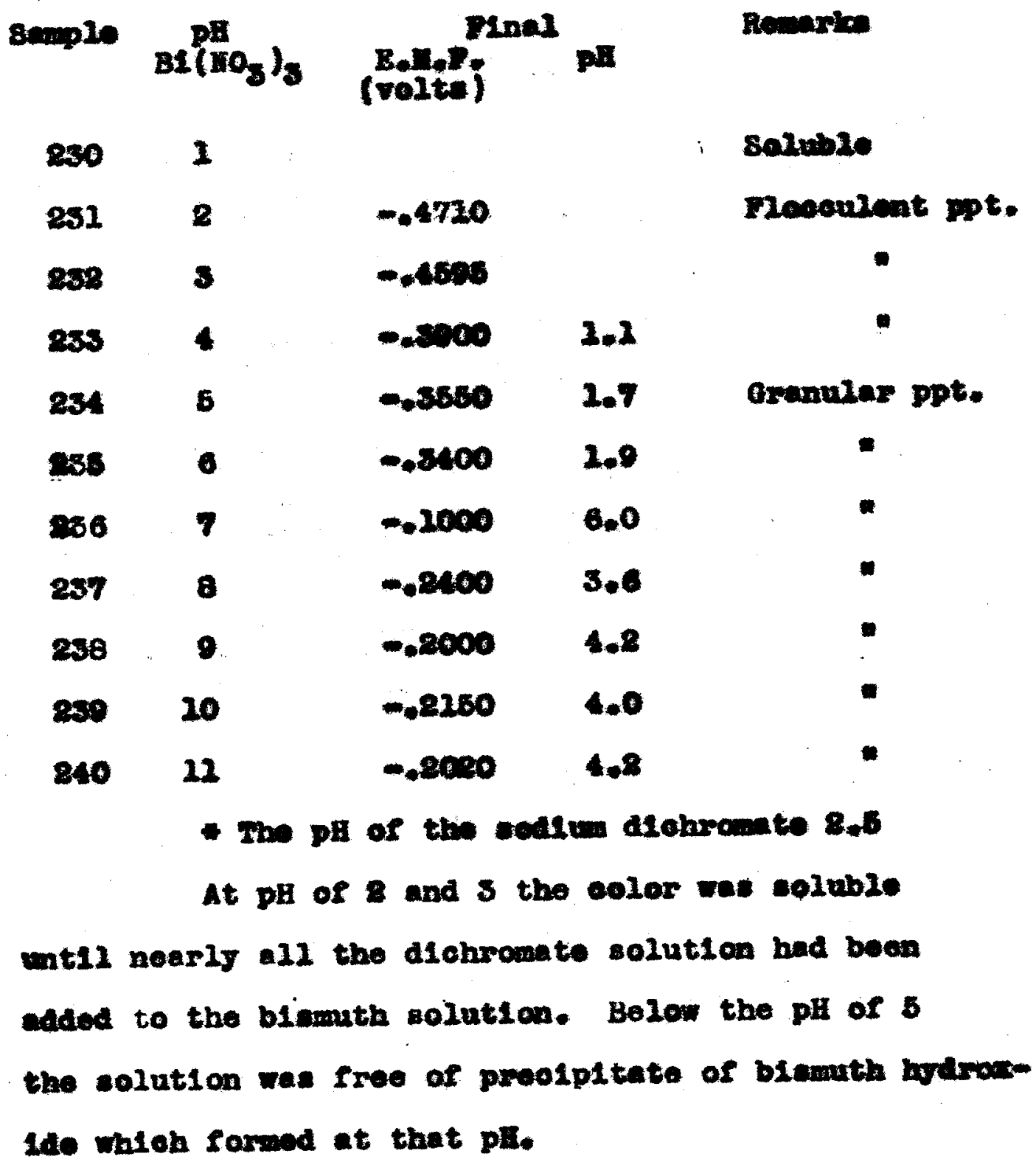


rable w.

Camparieon of Pulp Colore Propared from Bledath Iltrate and sodiw Diehromate

Somplo Indax

Itwe of color

$231 \quad$ PO -52

238 $P=5 I$

233 P20-5L Primeriln $y_{\text {, Golden Rod }}$

234 PIO- II Ifght Chrowe $Y_{i}{ }^{P}$

236 P2O- IL Ifght Chrome $I^{P}$

836 PL- $\pi$ Toneel, Deep stone

257 P10. $6 \mathrm{~J}$ Coin

238 P1O- 55 Carm

289 P10m $5 \mathrm{~J} \quad$ Godx

240 P20-5J Corra

- Colore propared undor conditione or

Table LrV.

Thte group of colore varied from a light

arange to a yellow at lo. 233, then to a slightly deriver yellom at 10. 235. 100. $236-240$ - $11 \mathrm{had}$ about the and oolor with a definlte wotallie lwoter. 
2ab2 $27 x$

Gemparisca of uase Tone of Colors Propared Srom Blamth Bltrate and Sodiu Diehromato.

8ouple Index Haw of celer

$232 \quad$ P24- 92

238 P25-12L Buffe20

235 P16-122 Partridge, Raw amber

234 PIO- $4 J$ Primrose $X_{0}$ snapdragen

236 P12- 72 Buraishod cold

236 PII- 25 Plnepple

237 PL1- 53 Buttoroup

258 PLI- $4 J$ Mastara

230 PL1- $4 J$ Mustara

840 P18-4L, Sulphine $I$

* Celore propared under conditions of

Table hrV.

Thle group of colore wes very variablo. 100. 231 - 233 were broms, No. 234 wae a mollw gollon Ho. 235 a tan, and yos. 236 - 840 ware 1 11ght tan or a croan. The break was et PE of 4 (10. 235) Irem a brom to a jellem. 


\section{Color Chaxt 27.}

Sample pH Niame of color.

2312

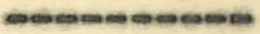

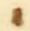

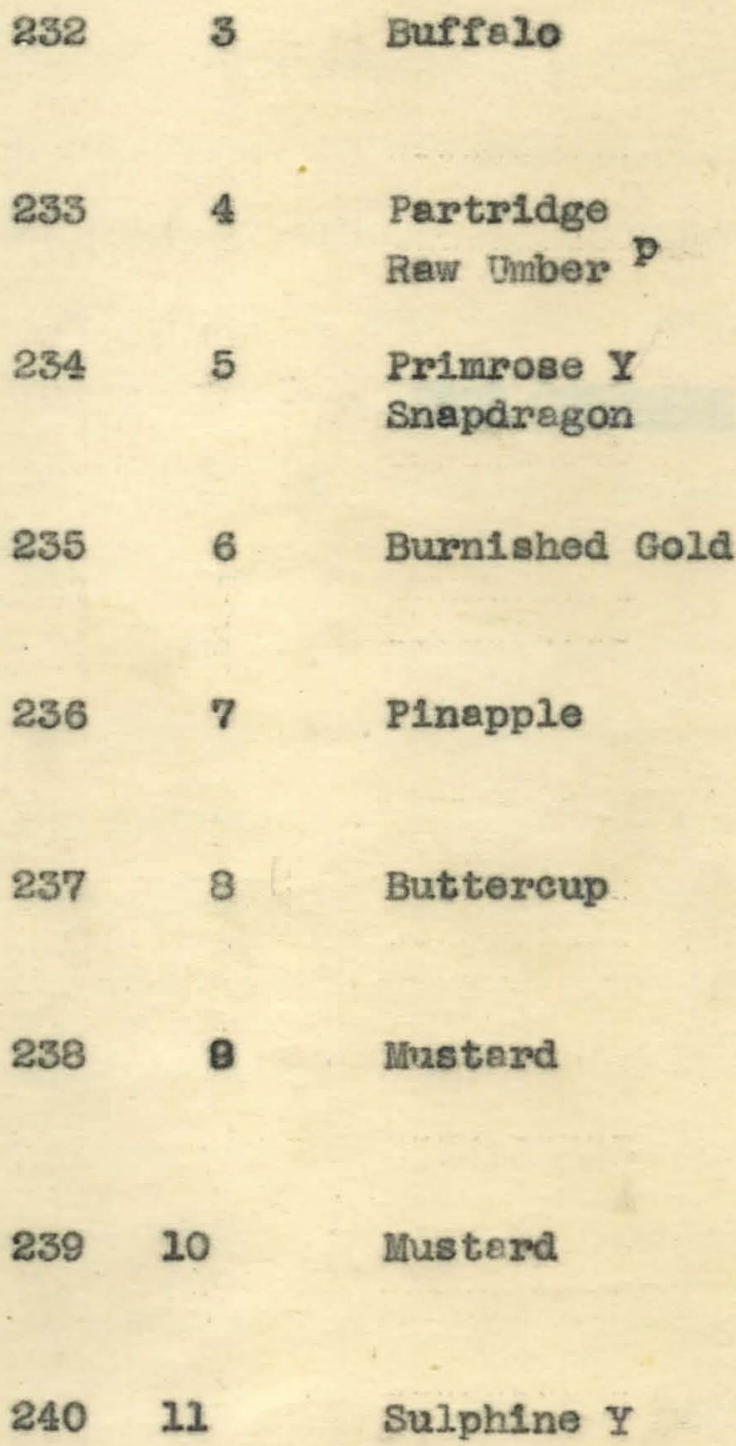

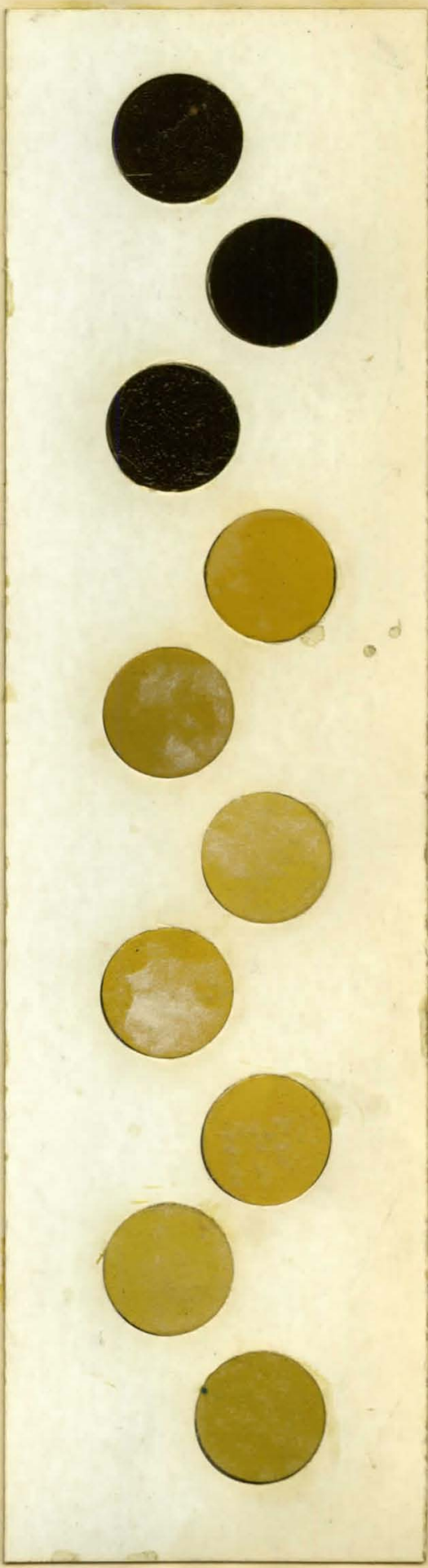


Inom Ginomins 
Dren Chromate.

It is ecareely to be expoeted that noxmi

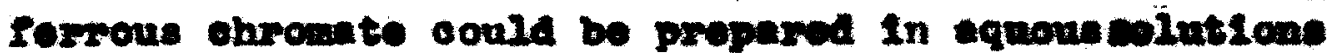
boeawe of the cridiling power of the chromates and ohremis aeld. I.ll.Vauquelin (s) obtalned geliem1ab-brown proelpitate from forrous oulphate and potanolwa shromate, whioh upon analjel: wae found to be a basio conplex formio salt. Several experimentere falied to obtain the normal formis chromato. Ferryl obromate $\left((\mathrm{FeO})_{\mathrm{g}} \mathrm{CrO}_{4}\right)$ a brom procipitate is prepared by the action of potaselum ohromate on solution of - remrie solt.

In this Investigation both the serroue and the forrite chloride solutions were used. It the sodium bydroxide was sded to the rerroue ealt, cerrous hydroxide was proolpitated whioh soon obenged to the forrie hydroxide. The proelpitite that formed, when the wolutlone of varying hydrogen Ion eonocntretione were etruak with the dichromate solution, had the charesterlet1e appearance and oolor of forrie bripocide, so vere not studied rurthor.

When the $p$ H of the forris selt wes rarled and the colution struok with dichromate selutica, the 


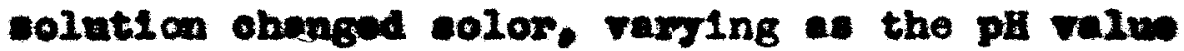
Inexoased. Whon the solution was basts cnough to

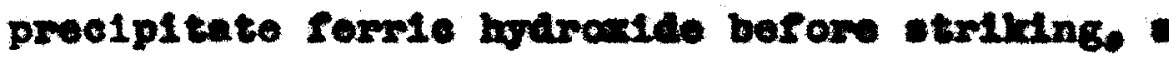
brown preolpitate formed thet wa a little darlor than those proviousif formed. Each wabhting removed scino of the obromate from the proelpitate, wats only the forrle bydroxide wes left. 
$\checkmark$

CoBnLF chomars 


\section{Cobalt Chremate.}

Poteneiven ohromate $\mathbf{1}$ th solutions of cobalt selt: gives rodelobmrom prostpitates whioh are probably a basie anit. Belges (18) obtalned the

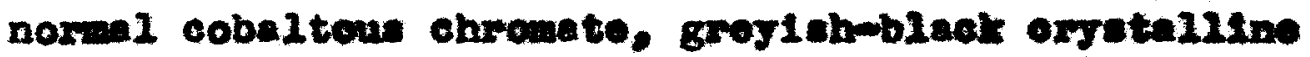
abutinee, by a method almilar to those bo weed for the preparation of othor ohromates, by boating the earbonete in ohronie sold at hlgh temporationes in a sealed tube. C. Frwese (6) prealpitated the eobeltous axyohromate from bolilng solutions of potaselum ohrowate and a cobeltous enlt. More oomplex salts of cobalt and ohromilum heve boen propared thon posalbly any othor elemont and ohrominn. 
Tabie ITrI.

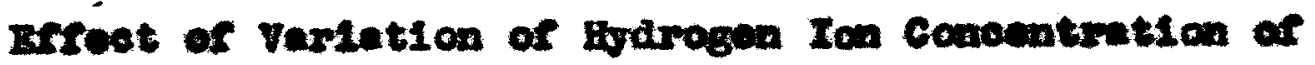
Cobltore Chieride solutioni with seditu

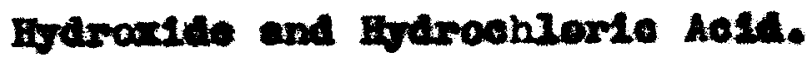
(Sodiu Dlohrenate" added to cobaltons ohloride.)

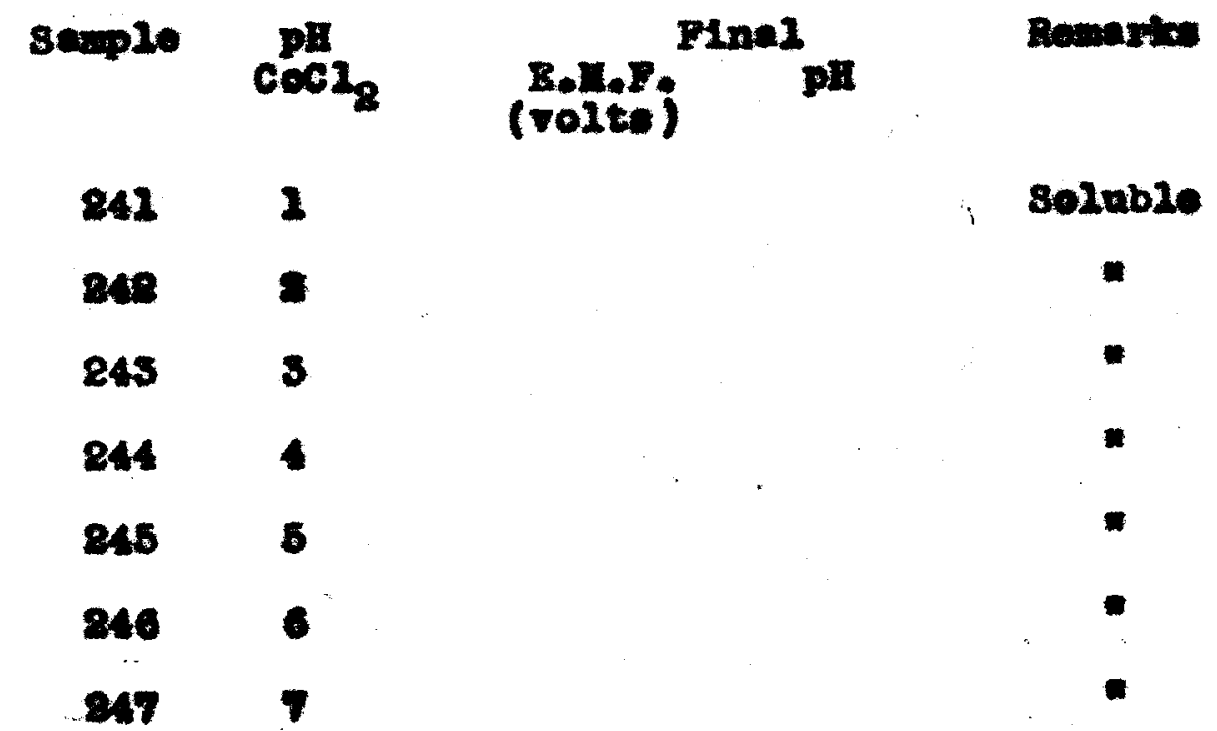

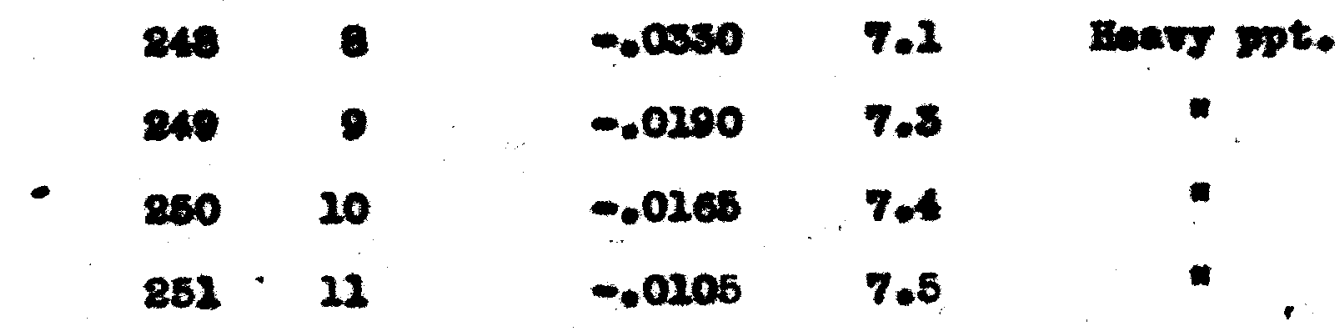

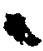

- the Ph of the sodiv diohremate 2.5. Tho proelpitates wase formed fren the besle selt which was ofthor a 21ght blue or almont a puple. 
Teble IVIII.

Cemparison of Pulp Colers Propared from Cobaltou Chloride and Sodiv Diehremato.

8atople Indax Iame of Color

Tame.

240 Fo -215 Iont Hold, Weathored onk"

250 Po -12L Handingy. Friar

251 P8 -1X, Ioar vold, weathored oak"

- Colore propared under conditions as

Table IVII.

A11 the colore wore a doep brom, and all prect10e117 the sane. I0s. 848 - 249 were slightly roder than othore.

\section{rable s.x.}

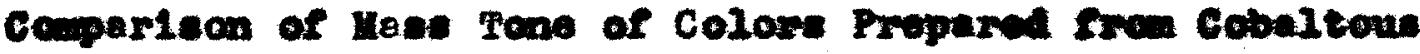
Chloxide and Sodiun Diohremete.

sample Inter " naw ar colos

24s, romilod chosolete

$249 \quad \mathrm{~F}-10 \mathrm{H} \quad$ Chosolato

$280 \quad P 8-20 R$ Chosolate

251. Pe-101 Chosolete

colore prepared undor conditione of

Table IVII.

A12 the oolore wore 1dent1ond, belng a enelelate brom. 
Table Ix.

Bffect of Variation of Hurogen Ion Concontmation of Sodive Dlohromate solution at th sellum

Hydrextde and Horochlorte Aold. (sodiu diehromte adad to cobaltow ebrorieb:)

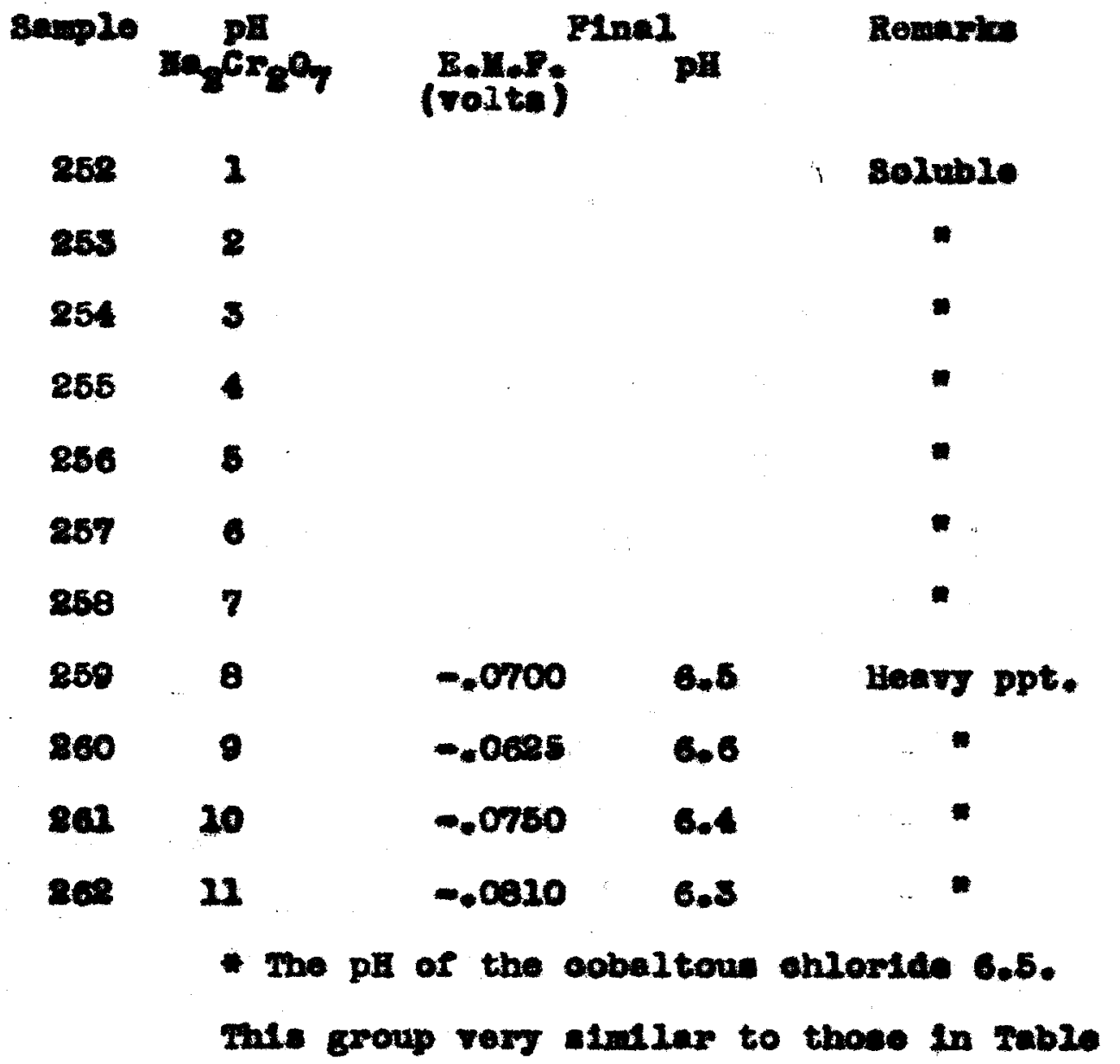

LVII. 
Tablo IxI.

Compariaon of Pulp Colore Propared Irom Cobalteut enloride and Soline Dióhromate.

\begin{tabular}{|c|c|c|}
\hline $\begin{array}{c}\text { 8ample } \\
000\end{array}$ & $\begin{array}{l}\text { Indox } \\
\text { Pn - igE }\end{array}$ & $\begin{array}{l}\text { Jome or Color } \\
\text { cosen. Turtio }\end{array}$ \\
\hline 260 & $P 7-128$ & Coose. TurtIo \\
\hline 261 & P7 - 2nn & Nolnawk, Noced \\
\hline 200 & $77-212 \mathrm{~B}$ & Holbuix, Heooa \\
\hline
\end{tabular}

Tabie Ix.

A12 oolore were modium brown.

Table IXIx.

Comperison of rias Tone of Colore Propared frem Cobsltows Chloride and Sodium Dichromato.

\begin{tabular}{|c|c|c|}
\hline Samplo & Index & Now of Coles. \\
\hline 259 & $P \theta-12 L$ & Manda 2ay. Helas \\
\hline 200 & $P a-12 x$ & Nande Iay. Friar \\
\hline 261 & $P B-12 L$ & Manda 1ay. Friar \\
\hline 262 & $P 8-12 L$ & Handajay. Friar \\
\hline
\end{tabular}

rable IX.

S11 colors were a modiun brewn. 
Color Chart 18.

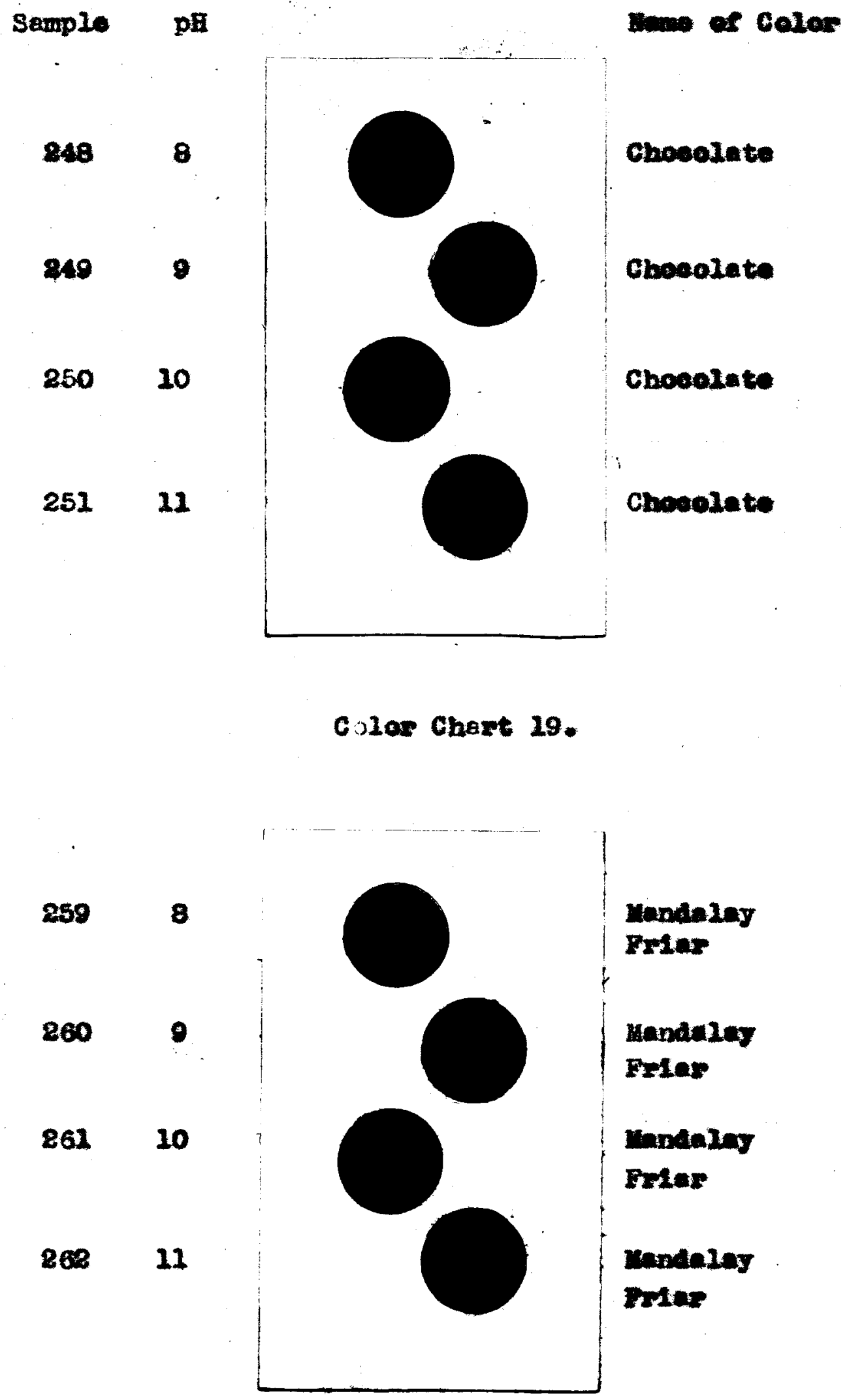




\section{MICKEL CHROZATES}




\section{Itekel Ehromate.}

Briggs (28) obtalned tho nomal ebrowate by mothods elmiler to those elwondy alsouned in the proparation of other chrowetos. Ho said that eltho nfokel ehromato 1 insoluble immater it will not proolpitate from niokel selt oolutions ond it must thorem" for be polymentred. The nownel nlokel ealt he pro-

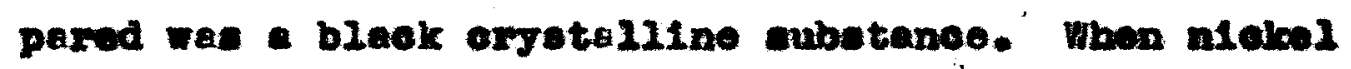

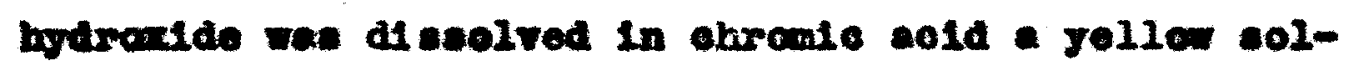
ution was formod, whloh deposited nondeleguoseont red oryatale. R. Puppute (3e) obeowed thet if the colution wee treeted with nickel earbonate or an

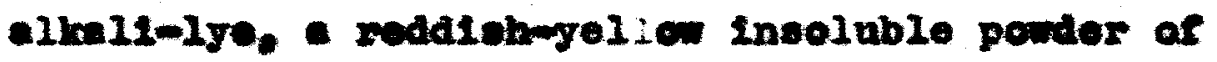
nlekel exychrowate was deposited. H. Greger (35) obteined brown amorphou preelpitate from a mixturo of 3 normal sodirm ohromate and nomal niolend olwowate, which was probably basto godlum nieled burowte. Ho obtelned a redaleh brom preelpitate from almilas solution of potaselua chromate and niokel ahromete, which beem potaselum nioled chromate when allewed to etand under ite mothor liquor. 
ande trato

Iffect of Variation of Hodrogen Ion canoentmatien of Mekel It twate solutions wth Mitrie sold and Bativi Hydroutle.

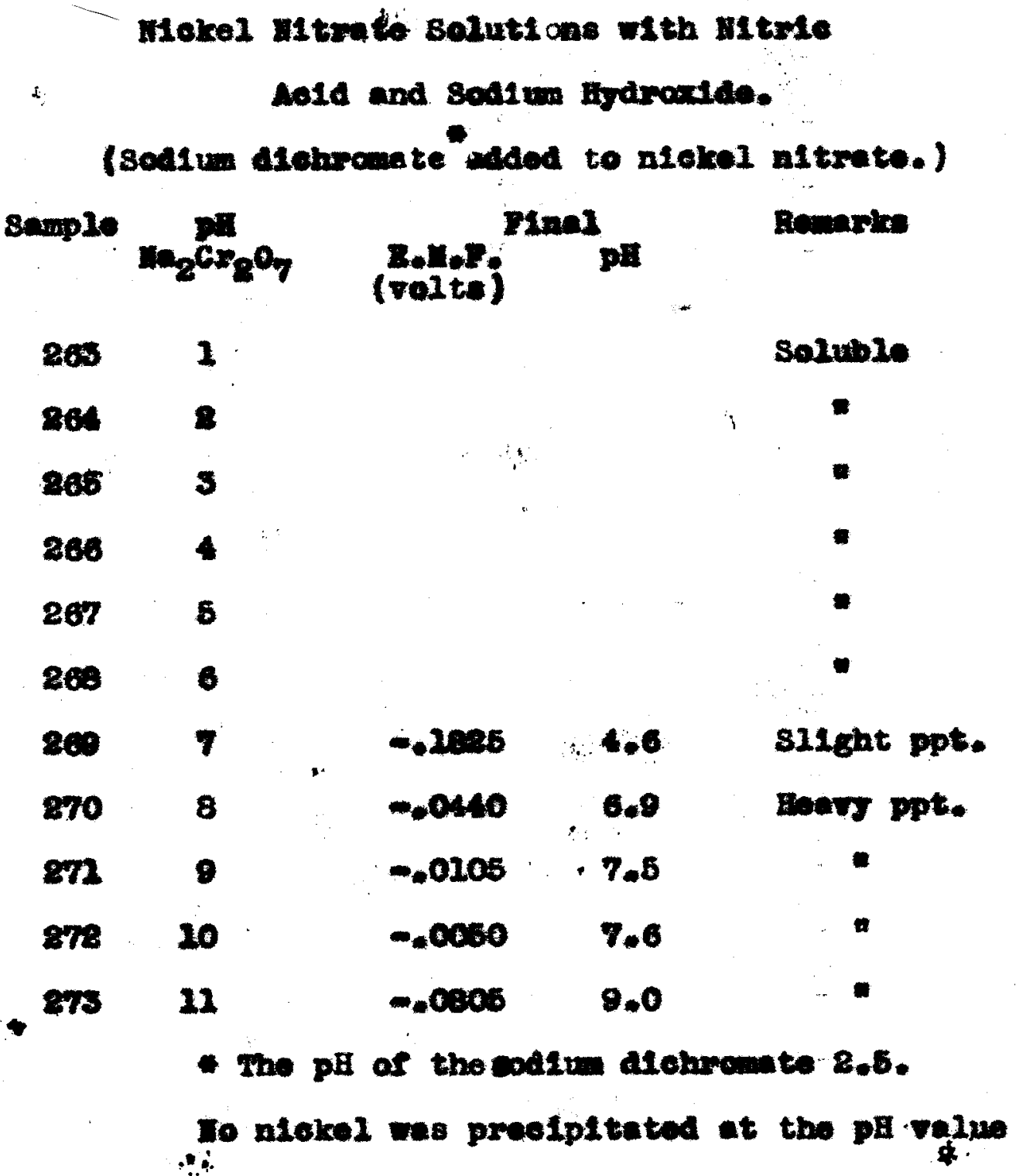
of 6 before etrilting, at pl velue of 7 alsght proolpitate fortad, and above af of 7 a heavy proolp 1tate of nidkel hydrextde was formed. 
rab20 IxIV.

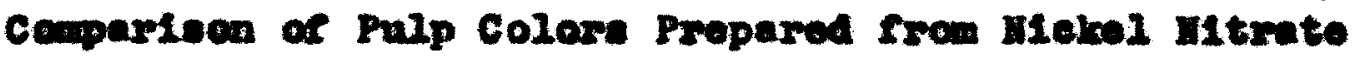
and sodiv Dichremete:

8xuplo Index tame of coler.

$870 \quad 76-285$ Copper B.

872 PE -12R Coppor Br

$279 \quad 96-125$ Copper Bs

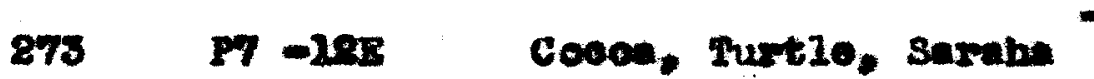

- Pulp colexs propared undpr conditions of

rab2o IxIrI.

All colore were a brom varying enly ellghtly to rea brown at io. 275 .

Table Lx.

Cemparison of lase rone of Colars proparod sren Mlokel Hltrate and solium Diehromate.

souplo Index tam of Color

870 Po $10 \mathrm{~T}$ Falecn, Muslarat

272 Fo -105 Peleca, nuskat

$272 \quad 70-10 \mathrm{~J}$ Falecn, Mualerat

273 P8 -20J Faleen, Mularat

* Colore prepered under conditions or

Table IXIII.

A2I colors wore Identiend balng a dark

red brown. 


\section{Color Chapt 20.}

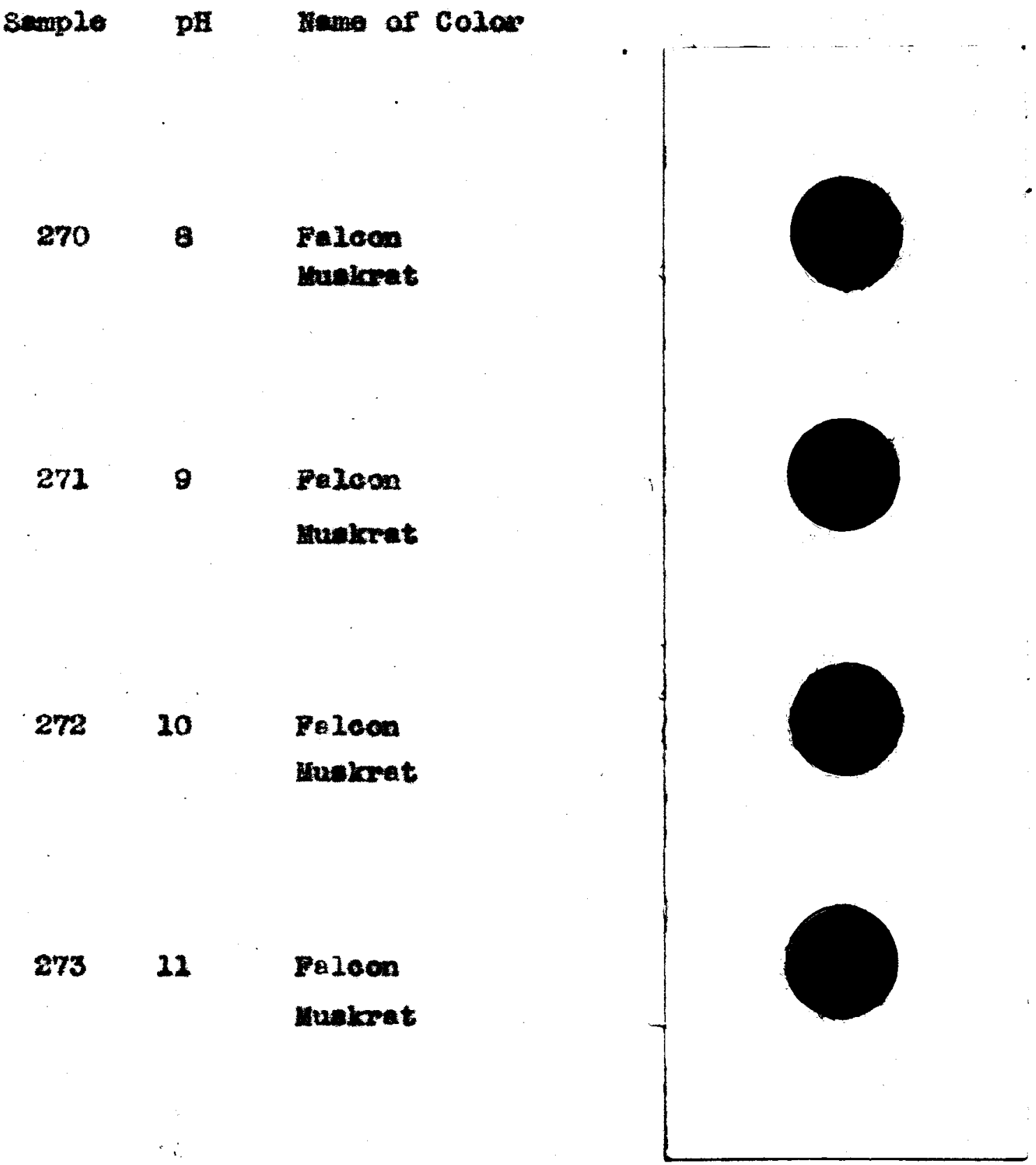




\section{2!na}




\section{onmonge}

The proolpitates propared in this invosm tigation wore elthor rellow, rodu or some semblnation of those croept in the ases of arsenie, In whteh ciase the procipitate was a croon. The proelpitates in wny canos did not form from acid salutions and in arces in whieh thes ald Iorn the proolpltate was arually very definlte in color, and raried ands elight2. Proelpitates thet formed from noutral or besie solutions ver rariable in color and in sawe oases were entirely afferent frow that furmod in the cold solutions. It in belleved that the varinblo colere are due to variable baste ehromates. The wothod of atriking had little or no effeet an the color in wost exwes, since wost of the groupe of colore propared by roveree mothode of strikIng wose vary comparable, and In sow oasen wore Idention.

The efreet of the variation of the hrdregen Ion ocneantrations had a mariced effeet in mont cason, and In all oases allghtly vaxying oolore were prodeced. The variation of the bydrogen ion ocncentration of the metalle salt had more marked effoct on the eolor 
than the variation of the pli of tho collum debremete. The colore prepared Irom eolutions that had the $\mathrm{PH}$ of the ealu diehromate varied vore mare or lene conatent in color with the indrease in tho PIn. Tho prealpitates formod from solutions that had the lodrom gen 10 concontration of the motellis ion selution varted worw. In wang osece, vory difforent and in sowe onses oven the ohareater of the prealpitate ohanged as the pH value was increased The onange In the color at a partiouler pll was not as dorinito is that of Iead ohromate. Imveotigated by Brmat (I) and othere, although many of the groups had a dorinite chenge at about the same pH velue as that of the lead ohromete (pH of 8). This obnes wes weully to a darion coles. It was notioed that for a partieniar mels. cxeopt thowe that forwed ocupleted insoluble ohromtes. tho proelpitate rownod in colutione having a Inal pll of approximate the name, rogardiose of tho wthod of striking, or the solution that had the hodregen ion coneentration raried. Io attempt wa made to doternine the oupesition of the procipiteted colore. 


\section{BIBITCORAPHY}

- insts. 


\section{Bebliogaphy.}

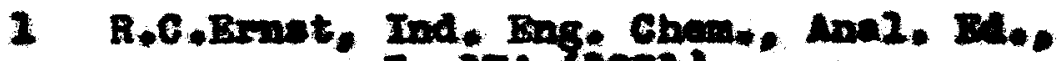
3. $174(2082)$.

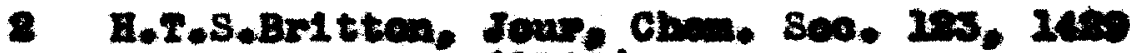
(102)

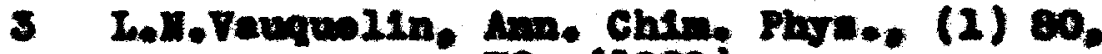
70. $(2000)$

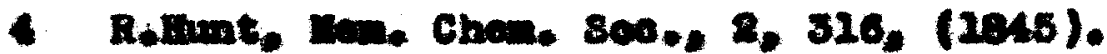

8 R.Bugh, Jowr. Ptore, Chom, 31, 032 (2087)

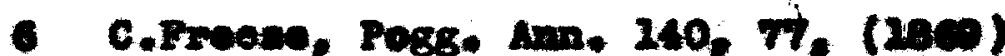

Pocs. Am. 140, 25, (106)

7 F.thiner, zolt. anors. Chom,. 96, 207, (2016)

- J.sehniso, 101a, 10, 150, (2008)

- Loll.Vanqulls, Ame Ghin. Fare. (1) 70 , 70. (1000).

10 Canching Patent I0. 266, 540 - Des. T. 1924.

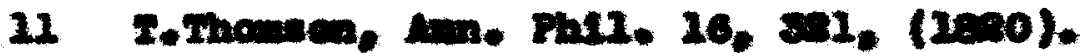

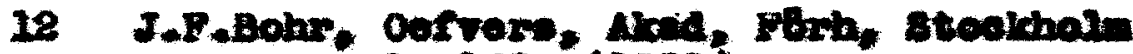
0. 200, (186e).

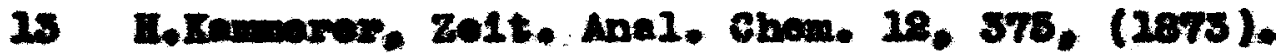

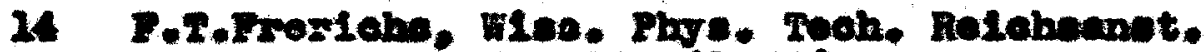
7. $600 .(3874)$.

15. Genedien Patent Ho, sca, 198

16 J.D.sut the Phin. Mag. (3) 8, 860,(2056).

I7 L, Bourgeole, Bull, 800, Min, 2, 123, (1870).

28 8.H.C.Br1gge, Ze1t, anorg, Chem, 56, 254, (1909) Ibld, 56, $247,(2003)$. 
2 Forea, DLe. Mnesmifarbon, Lolpals. 270. (2016).

20 A.Goutbor, Lolgtg's Ann, 106, 247, (1069).

21 A.J.Cer, zolt. anong, Chow, 40, 156, (10ed).

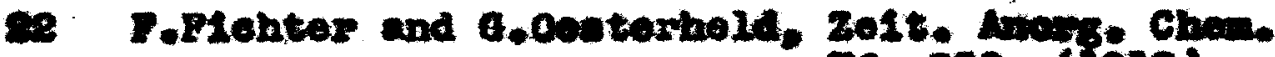
76. 359. (3018).

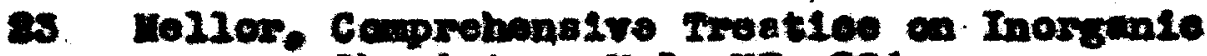
Chometry. Voi. XI, se4.

o4 M.Greger, Bex. 35, 3480,(2000).

25 S.H.C.Brigen. J.Chom, Soe+, 24a, (2020).

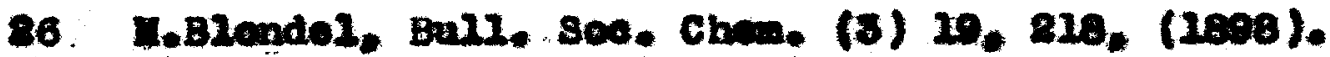

87 C.Palnos, Aner. Chen, Jous., 27. 974, (2005).

28 Introbar, Wonateh, $38,68,(2007)$.

29 J.J.Bariollu, Bohelggere Jour., 29.63 (1818).

30 J.LWw, Jour, Prakt, Chon., (I) 67.288 , 463. 1856.

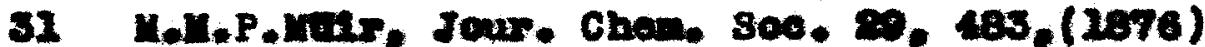

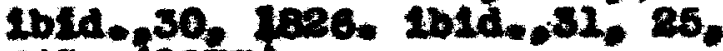
645. (1877).

38 H.trbger, 201t, anorg, Chem, 51, 558, (1006).

34 Bdimann, Ane Chtme, (0) 15, 200, (2021).

35 Stronven, Blo, Chem, Z, 208, 34-8 (2021).

36 n.tioeos,

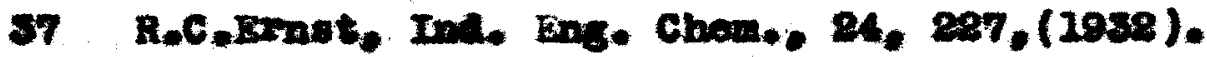

38 Laers and Paw, DLationary of Color. nooram-7421 Co. 1050. 